\section{unesp}

UNIVERSIDADE ESTADUAL PAULISTA "JÚLIO DE MESQUITA FILHO"

Campus de São José do Rio Preto

Aline Sumitani Murakami

\title{
Análise da espermatogênese e do comportamento nucleolar em espécies das famílias Alydidae, Coreidae, Pentatomidae e Reduviidae (Heteroptera)
}

Dissertação apresentada para obtenção do título de Mestre em Genética, área de concentração em Genética Animal e Evolução, junto ao programa de Pós-Graduação em Genética do Instituto de Biociências, Letras e Ciências Exatas da Universidade Estadual Paulista "Júlio de Mesquita Filho”, Campus de São José do Rio Preto, SP.

\section{BANCA EXAMINADORA}

Profa. Dra. Mary Massumi Itoyama

Professor Assistente Doutor

UNESP - São José do Rio Preto

Orientadora

Profa. Dra. Ester Tartarotti

Professor Doutor de Nível Superior

Universidade Federal de Mato Grosso do Sul

Profa. Dra. Maria Aparecida Marin Morales

Professor Assistente Doutor

UNESP - Rio Claro

São José do Rio Preto, 26 de Fevereiro de 2010 
Murakami, Aline Sumitani.

Análise da espermatogênese e do comportamento nucleolar em espécies das famílias Alydidae, Coreidae, Pentatomidae e Reduviidae (Heteroptera)

/ Aline Sumitani Murakami. - São José do Rio Preto : [s.n.], 2010.

145 f. : ; il. ; $30 \mathrm{~cm}$.

Orientador: Mary Massumi Itoyama

Dissertação (mestrado) - Universidade Estadual Paulista, Instituto de

Biociências, Letras e Ciências Exatas

1. Citogenética animal. 2. Espermatogênese. 3. Comportamento nucleolar. 4. Heteroptera. I. Itoyama, Mary Massumi. II. Universidade Estadual Paulista, Instituto de Biociências, Letras e Ciências Exatas. III. Título.

CDU - 575

Ficha catalográfica elaborada pela Biblioteca do IBILCE Campus de São José do Rio Preto - UNESP 
"Dedico esse trabalho à minha mãe e avós maternos que são meu exemplo de vida e sempre estiveram do meu lado, apoiando minhas decisões." 
“Agradeço a Deus acima de tudo, aos meus pais, meus avós, parentes e amigos por todo o apoio que me deram. Muito obrigada”! 


\section{AGRADECIMENTOS}

À Deus em primeiro lugar pelas oportunidades e pelo suporte a mim concedidos.

À minha mãe por ser meu porto seguro e sempre estar do meu lado na minha caminhada. Muito obrigada pelo amor, apoio, educação, compreensão e dedicação que eu tive na vida.

Aos meus avós maternos que ajudaram na minha criação e sempre torceram pelo meu sucesso.

Ao meu pai que, embora longe, sempre esteve do meu lado.

À minha orientadora pela transparência e confiança. Obrigada pela oportunidade de ser sua orientada.

À minha irmã que torce por mim.

À toda minha família que contribuiu, de alguma forma, na minha vida.

Aos meus amigos que sempre me apoiaram, pois como disse Vinícius de Moraes: "Eu poderia suportar, embora não sem dor, que tivessem morrido todos os meus amores, mas enlouqueceria se morressem todos os meus amigos"! Em especial as minhas amigas Quésia, Michele e Fabiana que me ajudaram em tantos momentos difíceis.

Aos meus amigos da Pós-Graduação pelo companheirismo, incentivo e ajuda na nossa jornada em busca de conhecimento. 
À todos os meus professores, pois sem eles não teria chegado onde estou hoje.

À todos os funcionários da UNESP que fazem essa universidade caminhar.

À todos que me ajudaram com minhas coletas.

Aos doutores Luiz Antônio Alves Costa do Departamento de Entomologia do Museu Nacional do Rio de Janeiro, RJ; José Antônio Marin Fernandes da Universidade Federal do Pará, PA e Hélcio Gil Santana do Instituto Oswaldo Cruz, RJ pela identificação dos insetos.

À Dra. Sônia Maria Oliani, pela disponibilização do seu laboratório e equipamentos para a captura de imagens.

À FAPESP, Fundação de Amparo à Pesquisa do Estado de São Paulo, pelo apoio financeiro.

À CAPES, Coordenação de Aperfeiçoamento de Pessoal de Nível Superior, pela bolsa concedida.

À Dra. Cláudia Regina Bonini Domingos e Dra. Lilian MadiRavazzi pela paciência e pelo auxílio durante a representação discente do ano de 2009.

Aos meus colegas de laboratório pelo convívio amigável e pelo auxílio durante o desenvolvimento do meu projeto. Em especial à Márcia, sempre disposta a esclarecer minhas dúvidas. 
"Bom mesmo é ir à luta com determinação, abraçar a vida e viver com paixão, perder com classe e viver com ousadia. Pois o triunfo pertence a quem se atreve e a vida é muito bela para ser insignificante".

\section{Charles Chaplin}




\section{SUMÁRIO}

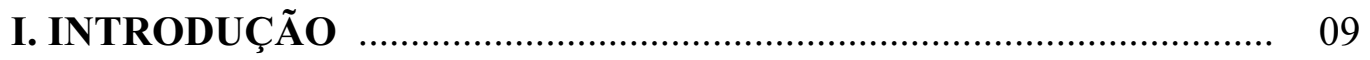

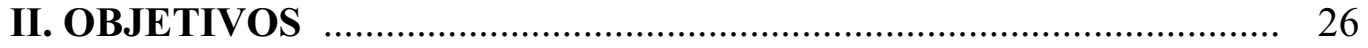

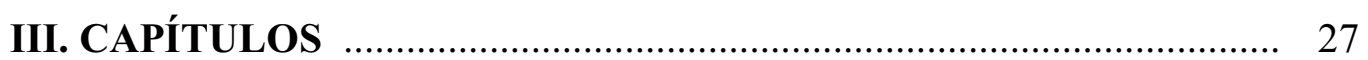

Artigo 1. Caracterização da espermatogênese em espécies das famílias Alydidae e Coreidae (Heteroptera) 28

Artigo 2. Caracterização dos lobos testiculares normais e harlequin de Chlorocoris complanatus e Loxa deducta (Heteroptera, Pentatomidae, Pentatominae)

Artigo 3. Comportamento da espermatogênese nos lobos testiculares de três espécies da família Pentomidae (Heteroptera)

Artigo 4. Semi-persistênca nucleolar em Atopozelus opsimus e Doldina carinulata (Heteroptera, Reduviidae, Harpactorinae) 95

IV. DISCUSSÃO GERAL

V. CONCLUSÕES

VI. REFERÊNCIAS BIBLIOGRÁFICAS

VII. ANEXOS 138

1. Material e Métodos 139

1.1. Obtenção e Armazenamento dos Insetos 139

1.2. Dissecação dos Insetos 139

1.3. Colorações 140

1.3.1. Orceína Lacto-Acética 140

1.3.2. Impregnação com Nitrato de Prata (HOWELL; BLACK, 1980, com modificações)

1.4. Análise das lâminas 141

Resumo 142

Abstract 
I. INTRODUÇÃO 


\section{INTRODUÇÃO}

Os Heteroptera, ou percevejos verdadeiros são os maiores e o mais diversificado grupo de insetos com metamorfose incompleta. Eles são geralmente tratados como uma subordem dos Hemiptera e a maioria de suas 75 famílias ocorrem em todos os continentes (exceto Antártica) e algumas ilhas. Sua antiga existência e aparente adaptabilidade têm resultado, sob o ponto de vista evolutivo, em extrema diversidade estrutural e biológica.

Nenhum outro grupo de insetos possui tamanha diversidade com relação ao habitat, como os Heteroptera. Eles vivem como parasitas de pássaros e mamíferos (morcegos) alimentam-se de todas as partes das plantas e de fungos, capturam outros artrópodes, vivem nas teias de aranhas, na água ou na sua superfície, com poucas espécies ocupando os oceanos. Eles podem ser fitófagos, predadores ou hematófagos (vetor da doença de Chagas aos humanos e a raiva aos morcegos).

Pelo fato da maioria dos Heteroptera serem fitófagos, eles podem atingir os humanos, pelos danos que causam às produções, por exemplo, de grãos (feijão, milho ou soja) que são utilizados para consumo, frutos (laranja, caju, bucha ou tomate), podem afetar a cadeia alimentar, ou mesmo transmitir algumas doenças às plantas, decaindo a produtividade. A importância econômica de vários Heteroptera também envolve muitas espécies que são benéficas, pois consomem insetos destrutivos. Algumas espécies são ectoparasitas de humanos e 
animais domésticos e poucos transmitem sérias doenças aos humanos (SCHUH; SLATER,1995).

Os Heteroptera possuem cromossomos holocêntricos (sem centrômero localizado), não possuem estrutura cinetocórica nas células meióticas (BUCK, 1967; COMINGS; OKADA， 1972; MOTZKO; RUTHMAN， 1984; RUFAS; GIMÉNEZ-MARTÍN, 1986; WOLF, 1996); a atividade cinética é restrita aos finais dos cromossomos, ou seja, nas regiões teloméricas (cromossomos são denominados telocinéticos) (SCHRADER, 1935, 1940; HUGHES-SCHRADER; SCHRADER, 1961; MOTZKO; RUTHMANN, 1984; GONZALEZ-GARCIA et al., 1996); terminalização dos quiasmas é presumido ocorrer (JOHN; KING, 1985), embora haja trabalhos que discutam este assunto (JONES, 1987; SOLARI; AGOPIAN, 1987); e a primeira divisão meiótica é reducional para os autossomos e equacional para os sexuais.

Além dos autossomos, os Heteroptera possuem os mcromossomos (microcromossomo). Wilson (1905) introduziu o termo mcromossomo para descrever o pequeno par de cromossomos em Hemiptera com comportamento diferente dos autossomos e dos cromossomos sexuais durante a meiose. Em Heteroptera, os m-cromossomos foram primeiramente descrito nos Coreidae por Paulmier (1899). Subseqüentemente foram encontradas em outras espécies (GROZEVA; KUZNETSOVA, 1989) das famílias Nepomorpha, Leptopodomorpha e Pentatomomorpha incluindo Lygaeidae, (UESHIMA, 1979). Os m-cromossomos geralmente não estão pareados durante o início da prófase meiótica I, mas na diacinese eles já aparecem juntos. Na metáfase I, eles estão 
sempre associados formando o pareamento "end-to-end" ("touch-and-go") como um pseudobivalente com segregação reducional na anáfase I. Na metáfase I, os autossomos arranjam-se em círculo e o m-pseudobivalente localiza-se no centro.O cromossomo X, geralmente, encontra-se fora do círculo formado pelos autossomos. Os m-cromossomos segregam-se equacionalmente na segunda divisão meiótica, assemelhando-se aos bivalentes autossômicos (BRESSA et al., 2001).

Os sistemas cromossômicos do sexo já descritos são os sistemas: simples $\mathrm{XY} / \mathrm{XX}(74,7 \%$ das espécies), X0/XX (14,8\%) e múltiplos (originados por fragmentação do cromossomo $\mathrm{X}$ e, menos freqüentemente, do cromossomo $\mathrm{Y}$, $\mathrm{XnO} / \mathrm{XnXn}, \mathrm{XnY} / \mathrm{XnXn}$ e $\mathrm{XYn} / \mathrm{XX}$, sistema este que corresponde a 10,3\% das espécies) (UESHIMA, 1979; MANNA, 1984). Há, ainda, um sistema particular neo-XY (CHICKERING; BACORN, 1933; SCHRADER, 1940; JANDE, 1959).

Uma das mais importantes questões relacionadas à evolução do cariótipo de Heteroptera é o problema da evolução do sistema cromossômico do sexo. O problema básico relacionado à evolução dos sistemas cromossômicos do sexo em Heteroptera é a questão de qual sistema é ancestral, X0 ou XY. O mecanismo mais comum em Heteroptera é o sistema XY, mas ao mesmo tempo o taxa mais plesiomórfico tem principalmente o sistema X0 (UESHIMA, 1979). O Sistema X0 é mais comum em insetos das ordens plesiomórficas como Odonata, Orthoptera, Psocoptera (WHITE, 1973). Este sistema está prevalecendo também na ordem Homoptera, juntamente com Heteroptera (HALKKA, 1959; KIRILLOVA, 1986, 1987). Ueshima (1979) acredita que o sistema XY evoluiu do 
sistema XO em Heteroptera, mas ele reconhece que a informação disponível é rica nas espécies apomórficas, e muito pobre nos taxons plesiomórficos (GROZEVA; NOKKALA, 1996).

Uma sugestão alternativa foi feita por Nokkala e Nokkala (1983), com base na descoberta de um cromossomo Y em uma espécie de Saldula (Saldidae) que pertence a um dos taxa mais plesiomórfico de Heteroptera. Nokkala e Nokkala (1984), observando espécies de Tingidae, verificaram que Dictyonota tricornis não possui cromossomo $\mathrm{Y}(\mathrm{X} 0)$ e isto é uma indicação de que houve perda deste cromossomo. Portanto, a perda de cromossomo Y em $D$. tricornis deve ter ocorrido depois, pois outras espécies de Dictyonota (D. fuliginosa) o possuem (NOKKALA; NOKKALA, 1984).

Enquanto a presença do sistema neo-XY é uma característica comum em outros insetos com cromossomos holocêntricos, tais como Odonata (MOLA; PAPESCHI, 1994), ele está quase que ausente em Heteroptera. Até a presente data, dentro de Heteroptera o sistema neo-XY foi observado somente em 4 espécies de Heteroptera: Lethocerus (Belostomatidae) (CHICKERING; BACORN, 1933; JANDE, 1959), Rhytidolomia senilis (Pentatomidae) (SCHRADER, 1940), Dysdercus albofasciatus (Pyrrhocoridae) (BRESSA et al., 1999) e Cacopsylla peregrina (Frst) (Psylloidea, Homoptera) (NOKKALA et al., 2003). Em Belostomatidae e Pentatomidae foi sugerido que a fusão de ambos os cromossomos $\mathrm{X}$ e $\mathrm{Y}$ ancestrais com um par de autossomos tenha ocorrido originando um sistema particular neo-XY (BRESSA et al., 1999). Os trabalhos de 
Bressa et al. (1999) mantém a hipótese de Ueshima (1979), assim o sistema neoXY evoluiu do sistema X0 ancestral (BRESSA et al., 1999).

Duas espécies de Psylloidea apresentam sistema cromossômico do sexo de $\mathrm{X}_{1} \mathrm{X}_{2} \mathrm{Y}$, um derivado do sistema neo-XY, uma condição polimórfica com o último (NOKKALA et al., 2003).

Foi proposto em D. albofasciatus (BRESSA et al., 1999) que a origem do sistema cromossômico neo é complexa. Dysdercus possui duas características que merecem atenção: presença de dois corpos positivamente heteropicnóticos e DAPI-brilhante de tamanhos diferentes em um dos seis cromossomos bivalentes e a restrição do crossing-over na região terminal dos cromossomos sexuais. Levando em consideração que a origem do sistema cromossômico do sexo foi a partir de $\mathrm{X} 0 / \mathrm{XX}$, inicialmente o cromossomo $\mathrm{X}$ ancestral foi inserido em um autossomo na posição subterminal. Através de uma grande inversão envolvendo a maioria do neo-X, dividiu o cromossomo $\mathrm{X}$ original em dois segmentos de tamanho diferentes (BRESSA et al., 1999).

Uma outra hipótese é a de que o sistema neo-XY é derivado do sistema XO por fusão do cromossomo X com um autossomo, resultando no cromossomo neo-X e o homólogo é transformado em cromossomo neo-Y. A presença do sistema neo-XY é revelado por cromossomo sexual bivalente, com quiasma heteromórfico na meiose de machos e uma diminuição no número de autossomos no cariótipo. Estas características são também típicas para sistema neo-XY em Psylloidea com somente poucas exceções (NOKKALA et al., 2003). 
O comportamento da estrutura do cromossomo neo-XY durante a meiose é de particular interesse porque, em Heteroptera, os cromossomos sexuais são positivamente heteropicnóticos durante a prófase I e sofrem segregação cromatídica na anáfase I enquanto os autossomos são eucromáticos e exibem crossing-over e segregação normal (JACOBS, 2004).

Durante leptóteno-paquíteno, ambos os cromossomos sexuais originais são heteropicnóticos e associados, tornando um corpo circular com o cromossomo individual não identificável enquanto que todos os autossomos e parte autossômica do neo-X são eucromáticos e formam o filamento do paquíteno original (JACOBS, 2004).

Durante o estágio difuso, todos os autossomos e parte dos autossomos do neo-X tornam-se descondensados e as cromátides não são identificáveis. Os cromossomos sexuais originais ficam positivamente heterocromáticos e associados e formam um corpo circular (JACOBS, 2004).

Durante diplóteno-diacinese, os bivalentes individuais tornam-se visíveis e os cromossomos individuais tornam-se discerníveis de modo que os quiasmas são claramente visíveis, no bivalente autossômico maior e na estrutura neo-XY. Os dois autossomos menores, geralmente, formam duas estruturas quadripartidas, onde as quatro cromátides são conectadas por filamentos finos de cromatina. Os cromossomos sexuais originais são ainda positivamente heteropicnóticos, mas tornam-se separados um do outro. O cromossomo $\mathrm{X}$ original é freqüentemente separado do autossomo onde ele se fusionou, ficando ligado a ele por dois filamentos muito finos. $\mathrm{Na}$ diacinese tardia, estes fios 
tornam-se mais evidentes e a parte heteropicnótica do X do neo-X move-se para a parte do autossomo. Durante o diplóteno-diacinese, o neo-XY, sem exceção, possui um quiasma e sua estrutura depende de onde ocorreu o crossing-over. A maioria do crossing-over está localizada na parte distal da estrutura (JACOBS, 2004).

Os aspectos meióticos dos Heteroptera são os seguintes: no leptóteno-zigóteno o cromossomo X é positivamente heteropicnótico e localiza-se na periferia do núcleo; no zigóteno e paquíteno, os cromossomos estão emaranhados. O paquíteno é seguido por um proeminente estágio difuso observado em todas as espécies selvagens, mas não nas espécies intercruzadas. Durante este estágio os bivalentes autossômicos não se descondensam completamente, apresentando, dessa maneira, várias regiões heteropicnóticos, enquanto que o cromossomo $\mathrm{X}$ permanece heteropicnótico e associado com o nucléolo. Além disso, o tamanho das células aumenta e o núcleo assemelha-se com o estado interfásico, sendo denominado de estágio difuso, após o diplóteno. No final da diacinese o cromossomo $\mathrm{X}$ torna-se isopicnótico. Na metáfase I, o cromossomo $\mathrm{X}$ localiza-se no centro do anel formado pelos autossomos bivalentes. $\mathrm{Na}$ anáfase I, os autossomos bivalentes dividem-se reducionalmente, enquanto o cromossomo $\mathrm{X}$ divide-se equacionalmente. A segunda divisão seguese diretamente após a telófase I, sem os estágios restantes. Na metáfase II, os autossomos dispõem-se no plano equatorial formando uma configuração em anel, com o cromossomo X no centro (BRESSA et al., 2002). Após a telófase II, as células filhas formadas, terão como destino o processo de espermiogênese, pela 
diferenciação dos espermatócitos e elongação dessas células.

Até a revisão de Rebagliati et al. (2005), mais de 1200 espécies de Heteroptera pertencentes a 42 famílias tinham sido citogeneticamente analisadas. O número de cromossomos diplóide encontrado varia de quatro (Lethocerus sp, Belostomatidae) a 80 (quatro espécies de Lopidae, Miridae). Dados citogenéticos de Pentatomoidea referem-se a 391 espécies pertencentes a somente nove famílias: Acanthosomatidae (12 espécies), Cydnidae (14 espécies), Dinidoridae (12 espécies), Plataspididae (16 espécies), Tessaratomidae (nove espécies), Thaumastellidae (duas espécies), Scutelleridae (27 espécies), Urostylididae (cinco espécies), e Pentatomidae, que é a mais amplamente estudada (294 espécies).

Os Coreidae compreendem alguns dos maiores Heteroptera assim como outras espécies que são delicadas ou delgadas. Eles são amplamente distribuídos, embora sejam mais abundantes em regiões tropicais e subtropicais e são, nestas áreas, os que atingem os maiores tamanhos e a maioria possuem aparências estranhas. Um número significativo de espécies, desta família, é de importância econômica (SCHUH; SLATER,1995).

O sistema cromossômico do sexo prevalente é o X0/XX (macho/fêmeas) e uma característica distinta, na maioria das espécies, é a de apresentar um par de m-cromossomos, que são aquiasmáticos, associam-se como um pseudobivalente no centro da placa metafásica I e sofrem divisão préreducional (WILSON, 1905; BRESSA et al., 2001). Em espécies já descritas de Coreidae, o número diplóide de cromossomos varia de $13(10 \mathrm{~A}+2 \mathrm{~m}+\mathrm{X} 0)$ a 28 
$\left(24 \mathrm{~A}+2 \mathrm{~m}+\mathrm{X}_{1} \mathrm{X}_{2} 0\right)$, sendo que a maioria apresenta 21 cromossomos (UESHIMA, 1979; SANDS, 1982; MANNA, 1984; COLOMBO; BIDAU, 1985; DEY; WANGDI, 1988; SATAPATHY; PATNAIK, 1989; CATTANI; PAPESCHI, 2004).

Os Alydidae são insetos relativamente pequenos, sendo encontrados, geralmente, no Norte da América em folhagens e flores (FROESCHNER, 1988). O número cromossômico diplóide de Alydidae é de 2n= $13(10 \mathrm{~A}+2 \mathrm{~m}+\mathrm{X} 0)(\mathrm{LESTON}, 1956$; UESHIMA, 1979). Todas as espécies de Alydidae descritas citogeneticamente possuem m-cromossomos e um único cromossomo X na meiose de macho (DA CUNHA MARQUES, 1945; MANNA, 1951; UESHIMA, 1979), com exceção de Akbaratus fasciatus ( $\mathrm{X}_{1} \mathrm{X}_{2} \mathrm{Y}$, PASCHAL, 1957 apud SANDS, 1982).

A família Pentatomidae é, em número de espécies, uma das maiores de Heteroptera, sendo cosmopolita e com maior diversidade nos trópicos. Conta com aproximadamente 760 gêneros e 4.112 espécies (SCHUH, SLATER, 1995; SCHAEFER, PANIZZI, 2000). Esses insetos são conhecidos como Mariasfedidas devido à produção de um odor desagradável emitido pelos ductos das glândulas produtoras de cheiro, que se abrem na região do metapleura. Schuh e Slater (1995) incluiram oito subfamílias nesta família: Asopinae, Cyrtocorinae, Discocephalinae, Edessinae, Pentatominae, Phyllocephalinae, Podopinae e Serbaninae. Os fitófagos economicamente mais importantes são espécies pertencentes às subfamílias Edessinae e Pentatominae, e englobam a maioria das espécies que são pragas de grãos. As espécies pertencentes a Asopinae são 
predadoras, e algumas dessas são importantes agentes de controle biológicos (SCHAEFER; PANIZZI, 2000 ).

Os Pentatomidae apresentam número diplóide de $2 \mathrm{n}=14$ cromossomos, sistema cromossômico do sexo XY/XX e não possuem mcromossomos. Entretanto, uma característica particular de algumas espécies é a presença de uma meiose anormal em um lobo testicular particular, denominado de lobo harlequin (SCHRADER 1945a, b, 1946a, b, 1960a, b).

Entre os Heteroptera, a família Reduviidae destaca-se por apresentar espécies insetívoras, fitófagas e hematófagas, sendo portanto, de grande importância, por exemplo, para a agricultura por comprometer a produtividade e saúde humana, pois podem transmitir a doença de Chagas durante a hematofagia. Por serem de maiores dimensões que os demais percevejos predadores, os reduviídeos consomem não só um maior número, como também, um maior espectro de espécies de presas (PANZERA et al., 1992).

O número diplóide de cromossomos, mais freqüente, nas espécies de Reduviidae é de $24(22 \mathrm{~A}+\mathrm{XY})$ e o sistema cromossômico do sexo mais comum é o $\mathrm{XY}$, mas são encontrados, também, para os machos os, $\mathrm{X}_{1} \mathrm{X}_{2} \mathrm{Y}$, $\mathrm{X}_{1} \mathrm{X}_{2} \mathrm{X}_{3} \mathrm{Y}$ ou $\mathrm{X}_{1} \mathrm{X}_{2} \mathrm{X}_{3} \mathrm{X}_{4} \mathrm{Y}$. Há relatos, também, da presença de m-cromossomos (UESHIMA, 1979).

Sabe-se que o tamanho do nucléolo é relacionado com a atividade biossintética da célula, portanto, o tamanho e o número de nucléolos e corpos pré-nucleolares dependem das características funcionais das células e podem refletir, então, em diferenças metabólicas e funcionais (TAVARES; 
AZEREDO-OLIVEIRA, 1997). A persistência do nucléolo e dos corpos prénucleolares, observados através da meiose de D. imitator (BRESSA et al., 2003), pode então estar relacionado com a intensa atividade sintética a fim de produzir RNAr requerido para a espermatogênese. Entretanto, a possibilidade que a alta taxa de transcrição de RNAr, relacionada a um outro fator desconhecido, não pode ser descartado (BRESSA et al., 2003).

O número e a localização das regiões organizadoras nucleolares (RON) foram determinadas em poucas espécies de Heteroptera por diferentes técnicas e diferentes resultados foram relatados. Em todos eles, uma única RON foi observada na posição mediana ou subterminal nos autossomos ou nos sexuais (CAMACHO et al., 1985; FOSSEY; LIEBENBERG, 1995; GONZALEZGARCIA et al., 1996; TARTAROTTI; AZEREDO-OLIVEIRA, 1999 PAPESCHI; BRESSA, 2002; PAPESCHI et al., 2003; REBAGLIATI et al., 2003).

Nos Pentatomidae uma única RON foi detectada na região telomérica de um par de autossomos em Edessa meditabunda (REBAGLIATI et al., 2003), na posição mediana em um par de autossomo grande em Nezara viridula (CAMACHO et al., 1985; PAPESCHI et al., 2003) e na região telomérica do cromossomo X de Graphosoma italicum (GONZALEZ-GARCIA et al., 1996).

O primeiro sistema para classificação dos espermatozóides em invertebrados utilizou o complemento cromossômico para distinguir os diferentes tipos (MEVES, 1903). Espermatozóides com complemento cromossômico haplóide foram denominados eupirenes, aqueles com números superiores aos 
haplóides foram chamados de hiperpirenes e os com o complemento inferior ao haplóide foram denominados de oligopirenes. Os espermatozóides apirenes não contêm cromatina. Inicialmente era aceito que muitos destes espermatozóides com morfologia alternativa, particularmente aqueles com divergência no conteúdo de cromatina, não poderiam fertilizar e, portanto, eram chamados de atípicos. Healy e Jamieson (1981), entre outros, sugeriram que os espermatozóides não fecundantes fossem chamados de paraespermatozóides e os fertilizantes de euespermatozóides.

As funções possíveis dos espermatozóides heteromórficos em insetos foram primeiramente descritas por Sivinski (1980), enquanto Silberglied et al. (1984) discutiram o possível papel dos espermatozóides apirenes em Lepidoptera. Swallow e Wilkinson (2002) elaboraram uma hipótese com relação às possíveis funções dos espermatozóides heteromórficos e as dividiram em quatro categorias diferentes: non-adaptative (não possui função), provisioning (inicia a capacitação dos espermatozóides e fornece nutrientes para as fêmeas, euespermatozóides e óvulo), facilitation (auxilia a migração dos euespermatozóides nos testículos e nas fêmeas) e competition (remove/tira os espermatozóides estocados e inutiliza-os).

Os testículos de todas as espécies de Pentatomidae consistem de um número de subdivisões, compartimentos ou lobos. O número mais comum de lobos é sete, embora haja variações entre tribos e espécies. As características dos espermatozóides (tamanho e/ou ploidia) diferem entre lobos nos testículos (SWALLOW; WILKINSON, 2002). Montgomery (1898 apud SCHRADER, 1960a) classificou, pela primeira vez, os espermatozóides de Pentatomidae em 
três classes: grande, médio e pequeno. Por exemplo, em Arvelius albopunctatus o volume da classe dos espermatozóides grandes é, aproximadamente, oito vezes maior do que o pequeno (SCHRADER; LEUCHTENBERGER, 1950). Em todos os casos descritos, a produção de espermatozóides de tamanhos diferentes está associada com lobos particulares nos testículos. Dois dos lobos dos testículos produzem o espermatozóide com morfologia maior. Estes lobos flanqueiam um lobo simples dos testículos que produzem os espermatozóides de morfologia menor. Os lobos remanescentes produzem os gametas de tamanho médio. É importante ressaltar que estes espermatozóides de classes diferentes resultam de meiose normal. Assim, o conteúdo de proteína e RNA das diferentes classes de espermatozóides está positivamente relacionado ao tamanho, enquanto o número cromossômico haplóide permanece constante. Tamanho dos espermatócitos não é correlacionado com o tamanho do lobo. De fato o lobo que produz o espermatozóide de tamanho menor é freqüentemente o maior e o lóbulo que produz o espermatozóide maior é o menor (SCHRADER, 1960a,b; SCHRADER; LEUCHTENBERGER, 1950).

A polimegalia descrita anteriormente difere completamente de um segundo processo visto que em um pequeno subgrupo de espécies da subfamília Pentatominae, o qual resulta não somente em espermatozóides de diferentes tamanhos, mas também de ploidias diferentes (BOWEN, 1922; SCHRADER, 1960a,b). Heteroploidia não é restrita para grupos monofiléticos, mas estão sendo relatados nas tribos Pentatomini, Halyini e Discocephalini. Resulta de um processo irregular de meiose dentro de um lobo simples do 
testículo, o número de cromossomos de espermátides em desenvolvimento varia de um, o qual sempre é o cromossomo sexual, até 100, mais do que 10 vezes o número haplóide de cromossomos esperados no gênero Loxa (BOWEN, 1922; SCHRADER, 1945a,b). Este lobo do testículo foi denominado de harlequin por haver discordâncias no processo de meiose normal. Este lobo corresponde ao maior, produz espermatozóides de morfologia menor, na maioria das espécies da subfamília, e torna-se então desproporcionalmente maior, relativo aos outros lobos, que em alguns casos, levam a formação de testículos torcidos ou enrolados. Schrader (1960b) observou que as condições fisiológicas e químicas dentro dos harlequins diferem dos lobos dos lobos normais.

Com relação a esta variação extraordinária no número cromossômico, há sugestões que isto deve estar relacionado com o desenvolvimento dos espermatozóides, resultando em espermatozóides de diferentes tamanhos, dependendo do conteúdo de cromossomos. O tamanho dos espermatozóides é proporcionalmente relacionado à quantidade de cromossomos. Mesmo que o desenvolvimento dos espermatozóides prossiga independentemente do número de cromossomos, evidências atuais indicam que somente estes espermatozóides contendo pelo menos um complemento completo de cromossomos sempre alcance o ducto ejaculatório (SCHRADER, 1960). Assim, o espermatozóide menor, com quantidade de cromossomos inferior ao número haplóide nunca deixa o aparelho reprodutor do macho.

Schrader (1945a, 1960a,b) surpreendeu-se como as forças da evolução tenham permitido a persistência dos lobos harlequins, uma estrutura que 
produz espermatozóides heteropoliplóides não usados na fertilização. Os autores sugeriram que eles devam fornecer nutrientes adicionais, especialmente nucleoproteínas para o desenvolvimento dos ovos. Como os espermatozóides do lobo harlequin são provavelmente não férteis, o argumento de ocorrência de poliespermia é duvidoso. Nem a ocorrência regular de poliespermia, em geral, nem entrada de espermatozóides do lobo harlequin nos ovos, em particular, foram investigados em Pentatominae (SWALLOW; WILKINSON, 2002). Embora não observados por Schrader, espermatozóides heteropoliplóides poderiam também ter outros papéis nutritivos, isto é, para as fêmeas ou para os espermatozóides fecundantes (SWALLOW; WILKINSON, 2002).

$\mathrm{Na}$ revisão de Schrader (1960), foi relatada uma aparente associação de heteroploidia em Pentatomidae com habitats tropicais e subtropicais onde o autor observou que mais de 20 espécies apresentavam tal característica. Nenhuma associação entre o lobo harlequin e a condição ecológica foi descrita.

A produção de espermatozóides de tamanhos múltiplos a partir de processo meiótico normal apresenta um mistério evolutivo quanto ao lobo harlequin. Embora muitas espécies de percevejos tenham espermatozóides polimegalos que variam somente em tamanho, mas tenham complemento cromossômico normal, todas as três morfologias de espermatozóides podem não participar igualmente da fertilização (SNOOCK et al., 1994). Ainda não foi demostrada a capacidade de fertilização dos espermatozóides de diferentes morfologias. Pelo menos para os espermatozóides maiores, um argumento nutricional similar aos que foram propostos para os espermatozóides harlequins 
(SCHRADER, 1960a,b) poderia ser vantajoso como uma possível superioridade para espermatozóides de múltiplas morfologias.

Pesquisas com Nezara viridula, provém alguns suportes para o papel nutritivo dos espermatozóides harlequin de tamanhos maiores. McLain (1998) observou que os machos que não copulavam tinham os lobos harlequin menores do que os que copulavam. O porquê das fêmeas sempre escolherem os machos com melhores sucessos reprodutivos, foi medido pelo número de ovos fertilizados durante a vida das fêmeas. MacLain (1998) inferiu que fêmeas receberam benefícios não-genéticos de preferência masculina (McLAIN; MARSH, 1990). McLain (1998) sugeriu que os benefícios não genéticos poderiam resultar de espermatozóides gigantes e multinucleados, se espermatozóides não fertilizantes fornecerem nutrientes para os ovos ou fêmeas. Para este argumento ser sustentado, a largura dos lobos harlequin deveria ser correlacionada com o tamanho ou número de espermatozóides produzidos neste lobo harlequin e no caso de benefícios nutricionais diretos para o ovo, poliespermia deveria ocorrer com alguma freqüência. 


\section{OBJETIVOS}

Pelas características anteriormente citadas de presença ou não de lobo harlequin, formação de diferentes tipos de espermatozóides, número variável de cromossomos, presença ou não de m-cromossomos, diferentes sistemas cromossômicos do sexo, poucos trabalhos relacionados com a citogenética (comportamento meiótico e nucleolar), o objetivo geral do presente trabalho foi de gerar conhecimentos que permitam melhor conhecer a biologia dos Heteroptera.

Os nossos objetivos específicos foram:

a) Analisar a morfologia do testículo para verificar, especialmente, a quantidade de lobos e a presença ou não de lobo harlequin;

b) Analisar, detalhadamente, a espermatogênese (comportamento meiótico e espermiogênese), através do esmagamento dos testículos de machos adultos corados com orceína lacto-acética, tomando-se o cuidado de analisar os lobos separadamente, se a espécie possuir o lobo harlequin;

c) Analisar o comportamento nucleolar, das espécies, durante a espermatogênese, através da técnica de impregnação com íons prata;

d) Procurar estabelecer relações filogenéticas entre as espécies com base nas observações mencionadas nos itens a, b e c. 
III. CAPÍTULOS 


\section{Caracterização da espermatogênese em espécies das famílias Alydidae e Coreidae (Heteroptera)}

MURAKAMI, Aline Sumitani; ITOYAMA, Mary Massumi.

UNESP-Universidade Estadual Paulista, Instituto de Biociências, Letras e Ciências Exatas, Departamento de Biologia, Laboratório de Citogenética e Molecular de Insetos-LACIMI

\section{Resumo}

Foram estudados aspectos citogenéticos das espécies Stenocoris (Oryzocoris) furcifera (Alydidae), Acanonicus hahni, Acantocephala sp e Anisoscelis foliacea marginella (Coreidae). Similarmente a outras espécies já descritas na literatura, todas apresentaram cromossomos holocêntricos, sistema cromossômico do sexo $\mathrm{X} 0$, presença de quiasmas intersticiais ou terminais, divisão reducional para os autossomos na primeira divisão e o inverso para os cromossomos sexuais. Uma das diferenças encontrada entre as espécies é a ausência de m-cromossomos em $S$. (Oryzocoris) furcifera e A. hahni. O número diplóide de cromossomos foi de $2 \mathrm{n}=$ $13(12 \mathrm{~A}+\mathrm{X} 0)$ em $S$. (Oryzocoris) furcifera, $2 \mathrm{n}=19(18 \mathrm{~A}+\mathrm{X} 0)$ em A. hahni, $2 \mathrm{n}=$ $21(18 \mathrm{~A}+2 \mathrm{~m}+\mathrm{X} 0)$ em $A$. sp e de $2 \mathrm{n}=27(24 \mathrm{~A}+2 \mathrm{~m}+\mathrm{X} 0)$ em A. foliacea marginella. $\mathrm{O}$ comportamento nucleolar durante a espermatogênese também foi semelhante quando comparou-se as diferentes espécies. Todas apresentaram um corpúsculo nucleolar durante a prófase, durante a metáfase o material impregnado pela prata foi observado na bainha pericromossômica e, somente em A. hahni observou-se a região organizadora nucleolar em um autossomo.

Palavras-chave: m-cromossomos, espermiogênese, cromossomo holocêntrico, quiasmas 


\section{Introdução}

Os Coreidae compreendem alguns dos maiores Heteroptera assim como outras espécies que são delicadas ou delgadas. Eles são amplamente distribuídos, embora sejam mais abundantes em regiões tropicais e subtropicais e são, nestas áreas, os que atingem os maiores tamanhos e a maioria possuem aparências estranhas. Um número significativo de espécies, desta família, é de importância econômica (SCHUH; SLATER, 1995). Diferentemente dos Coreidae, os Alydidae são insetos relativamente pequenos, sendo encontrados, geralmente, no Norte da América em folhagens e flores (FROESCHNER, 1988).

Nos Coreidae o sistema cromossômico do sexo prevalente é o $\mathrm{X} 0 / \mathrm{XX}$ (macho/fêmeas) e uma característica distinta na maioria das espécies é a de apresentar um par de m-cromossomos, que são aquiasmáticos, associam-se como um pseudobivalente no centro da placa metafásica I e sofrem divisão préreducional (WILSON, 1905; BRESSA et al., 2001). Em espécies já descritas de Coreidae o número diplóide de cromossomos varia de $13(10 \mathrm{~A}+2 \mathrm{~m}+\mathrm{X} 0)$ a 28 $\left(24 \mathrm{~A}+2 \mathrm{~m}+\mathrm{X}_{1} \mathrm{X}_{2} 0\right)$, sendo que a maioria apresenta 21 cromossomos (UESHIMA, 1979; SANDS, 1982; MANNA, 1984; COLOMBO; BIDAU, 1985; DEY; WANGDI, 1988; SATAPATHY; PATNAIK, 1989; CATTANI; PAPESCHI, 2004).

$\mathrm{O}$ número cromossômico diplóide de Alydidae é de $2 \mathrm{n}=13$ $(10 \mathrm{~A}+2 \mathrm{~m}+\mathrm{X} 0)(\mathrm{LESTON}, 1956$; UESHIMA, 1979). Todas as espécies de Alydidae descritas citogeneticamente possuem m-cromossomos e um único cromossomo X na meiose de macho (DA CUNHA MARQUES, 1945; MANNA, 1951; UESHIMA, 1979), com exceção de Akbaratus fasciatus $\left(\mathrm{X}_{1} \mathrm{X}_{2} \mathrm{Y}\right.$, PASCHAL, 1957 apud SANDS, 1982).

Sabe-se que o tamanho do nucléolo é relacionado com a atividade biossintética da célula, portanto, o tamanho e o número de nucléolos e corpos pré-nucleolares dependem das características funcionais das células e podem refletir em diferenças metabólicas e funcionais (TAVARES; AZEREDOOLIVEIRA, 1997). A persistência do nucléolo e dos corpos pré-nucleolares, 
observados através da meiose de Dysdercus imitator (BRESSA et al., 2003), pode estar relacionada com a intensa atividade sintética a fim de produzir RNAr requerido para a espermatogênese. Entretanto, não se pode descartar que a alta taxa de transcrição de RNAr poderia estar relacionada a outro fator, até o momento, desconhecido (BRESSA et al., 2003).

O número e a localização das regiões organizadoras nucleolares (RON) foram determinados pelo uso de diferentes técnicas em poucas espécies de Heteroptera sendo relatados diferentes resultados. Em todas estas análises uma única RON foi observada, mas em diferentes posições e cromossomos, tais como na posição mediana ou subterminal nos pares dos autossomos ou nos cromossomos sexuais (CAMACHO et al., 1985; FOSSEY, LIEBENBERG, 1995; GONZALEZ-GARCIA et al., 1996; PAPESCHI, BRESSA, 2002; PAPESCHI et al., 2003; REBAGLIATI et al., 2003; CASTANHOLE et al., 2008). Diante da importância econômica destes insetos, pois muitos são pragas de grãos, devido a diversidade no número de autossomos e diferentes sistemas cromossômicos do sexo e, ainda, as diferenças no comportamento nucleolar, o objetivo do presente trabalho foi $o$ de obter maiores informações sobre a espermatogênese (comportamento meiótico e espermiogênese) e o comportamento nucleolar, de Stenocoris (Oryzocoris) furcifera (Alydidae), Acanonicus hahni, Acantocephala sp e Anisoscelis foliacea marginella (Coreidae).

\section{Materiais e Métodos}

Quinze machos adultos de cada espécie de Stenocoris (Oryzocoris) furcifera (Alydidae), Acanonicus hahni, Acantocephala sp e Anisoscelis foliacea marginella (Coreidae) foram coletados no município de São José do Rio Preto-SP (2047'32"S, 49²1'37"W) em pés de ipê branco (Tabebuia roseo-alba), abobrinha (Cucurbita pepo), roseira (Rosa sp.) e maracujá (Passiflora suberosa), respectivamente. Após a coleta foram eterizados e dissecados, já que a espermatogênese em Heteroptera não se encerra no estágio de ninfa. Os testículos extraídos foram colocados e dilacerados em lâminas e corados 
com orceína lacto-acética ou impregnados por íons prata segundo protocolo modificado de Howell e Black (1980), para o estudo citogenético da meiose e espermiogênese. As amostras que não foram utilizadas logo após a coleta foram fixadas em metanol:ácido-acético (3:1) e mantidos a $8^{\circ} \mathrm{C}$. As lâminas foram analisadas no microscópio de luz Olympus modelo BX40 do Laboratório de Citogenética e Molecular de Insetos (LACIMI) e as melhores imagens foram capturadas no microscópio de luz AXIOSKOP 2 ZEISS (programa AXIOVISION) do laboratório de Morfologia, do Departamento de Biologia do IBILCE/UNESP, São José do Rio Preto - SP.

\section{Resultados}

Observação das células após coloração com orceína lacto-acética

Após dissecação das amostras de Stenocoris (Oryzocoris) furcifera (Alydidae) observamos que seus testículos são formados por 6 lobos alongados e envoltos por membrana vermelha. Nas amostras de Coreidae pode-se observar que os testículos de Acanonicus hahni, Acantocephala sp. e Anisoscelis foliacea marginella são formados por 7 lobos alongados e homogêneos em tamanaho em forma de concha e envoltos por membrana alaranjada, com exceção de Acantocephala sp na qual a membrana é avermelhada.

As análises das células espermatogoniais de todas as espécies de Alydidae e Coreidae permitiram a visualização do comportamento das células durante a meiose e observou-se que a espermatogênese das diferentes espécies são semelhantes, por esse motivo os resultados serão apresentados em conjunto.

A análise das células testiculares de todas as espécies permitiu visualizar que o processo de espermatogênese ocorre nos cistos espermatogoniais e que o mesmo é constituído por 8 espermatogônias (Figura 1a). Uma outra observação realizada é que o núcleo poliplóide das células nutritivas são maiores que as células meióticas e apresentam várias regiões heteropicnóticas em Coreidae 
(Figura 1b), enquanto que em Alydidae os núcleos poliplóides não apresentaram regiões heteropicnóticas evidentes (Figura 1c).

Durante a espermatogênese, observamos que as células meióticas em leptóteno/zigóteno apresentam um corpúsculo heteropicnótico arredondado fortemente corado que, possivelmente, seja o cromossomo sexual (Figura 1d,e). Este corpúsculo é observado até o final da prófase (Figura 1f,g). No diplóteno/diacinese podemos visualizar quiasmas intersticiais em todos os autossomos, por apresentarem morfologia em forma de cruz aos cromossomos (Figura 1f-i). Os quiasmas são mais facilmente observados nas espécies de Coreidae.

Em ambas as famílias o processo de condensação dos cromossomos ocorre, com a diferença de que em Alydidae esses agrupam-se dando morfologia em “Z” aos cromossomos unidos (Figura 1j). Já em Coreidae os cromossomos condensam-se isoladamente (Figura 1i). O agrupamento dos cromossomos de Alydidae, durante a condensação, pode ser observado até a metáfase I, onde ocorre a formação de 2 grupos de 2 ou 4 autossomos e o cromossomo sexual isolado (Figura 2a).

Na metáfase I observamos que o complemento cromossômico de $S$. (Oryzocoris) furcifera é de $2 \mathrm{n}=13(12 \mathrm{~A}+\mathrm{X} 0)$ (Figura 2a), de $A$. sp é de $2 \mathrm{n}=$ $21(18 \mathrm{~A}+2 \mathrm{~m}+\mathrm{X} 0)($ Figura $2 \mathrm{~b})$, de A. foliacea marginella é de $2 \mathrm{n}=27(24 \mathrm{~A}+$ $2 \mathrm{~m}+\mathrm{X} 0)$ (Figura 2c) e de $A$. hahni é de $2 \mathrm{n}=19(18 \mathrm{~A}+\mathrm{X} 0)$ cromossomos (Figura 2d). Portanto, todas as espécies apresentaram sistema cromossômico do sexo X0 e m-cromossomos, com exceção de S. (Oryzocoris) furcifera e A. hahni.

Observamos, ainda, na metáfase I em visão polar, que os autossomos formam um anel, com o cromossomo sexual localizando-se fora dele e os m-cromossomos posicionados na parte interna do anel (Figura 2b-d).

Na Figura 2e podemos observar uma célula em metáfase I, em visão lateral, com os cromossomos alinhados, prontos para iniciarem o processo de separação dos cromossomos homólogos (autossomos) ou das cromátides irmãs (cromossomo sexual). $\mathrm{Na}$ telófase $\mathrm{I}$, após a separação dos cromossomos/cromátides, observamos duas células com cromossomo sexual X 
fora do anel formado pelos autossomos (Figura 2f). Na anáfase II e telófase II (Figura 2g,h), podemos observar a migração tardia de apenas um cromossomo sexual, portanto, sugerimos que apenas uma célula receberá este cromossomo e a outra não o possuirá, como pode ser visto na Figura $2 \mathrm{~h}$.

$\mathrm{O}$ processo de espermiogênese inicia-se com espermátides arredondadas, cromatina moderadamente condensada, com um corpúsculo heteropicnótico arredondado e evidente e uma vesícula (Figura 2i). Posteriormente, as espermátides tornam-se menores e o material heteropicnótico arredondado é visualizado na periferia do envoltório nuclear (Figura 2j). No estágio mais avançado do desenvolvimento, o material heteropicnótico é visualizado em apenas um dos lados da espermátide (Figura 2k). Com o alongamento, o material heteropicnótico passa a ser observado na região posterior da cabeça, em Coreidae (Figura 21,n,o) e em quase todo o comprimento da espermátide em Alydidae (Figura $2 \mathrm{~m}$ ). A Figura $2 \mathrm{p}$ mostra a formação do espermatozóide.

Observação das células após impregnação por ions de prata

Pelo fato das células das espécies $S$. (Oryzocoris) furcifera (Alydidae), A. hahni, A. sp. e A. foliacea marginella (Coreidae), após impregnação por íons prata, terem apresentado comportamentos semelhantes, os resultados serão apresentados em conjunto. Os núcleos poliplóides apresentaram algumas regiões cromossômicas marcadas pelos íons prata (Figura 3a). As células em prófase (leptóteno/diplóteno) apresentam um ou dois corpúsculos nucleolares arredondados e fortemente corados (Figura 3b-f). No final da prófase I (diplóteno/diacinese), não observamos mais a presença do corpúsculo nucleolar. Há apenas algumas evidências de material prata positivo em algumas regiões da bainha pericromossômica (Figura 3g). Na metáfase I, observamos material prata positivo impregnado em algumas regiões da bainha pericromossômica (Figura 3h,i) em S. (Oryzocoris) furcifera e A. foliacea marginella. Em A. hahni há 
impregnação em algumas regiões da bainha pericromossômica e na RON (Figura $3 \mathrm{j})$.

As espermiogêneses de $S$. (Oryzocoris) furcifera, A. hahni e $A$. foliacea marginella apresentaram comportamentos diferentes. S. (Oryzocoris) furcifera apresentou espermátides iniciais com pequenos grânulos prata positivo (Figura 4a). Com o desenvolvimento, as espermátides elípticas passaram a apresentar uma tênue marcação em apenas um dos lados da membrana da cabeça (Figura 4b). As espermátides alongadas apresentaram 1 única marcação na região da cauda (Figura 4c). As espermátides arredondadas de A. hahni apresentaram pequenas marcações no interior do núcleo e alguns corpúsculos na região da vesícula (Figura 4d). Com o alongamento, as espermátides elípticas passaram a apresentar marcação somente na região posterior da cabeça (Figura 4e-h). Observar na Figura 4f que essas marcações são formadas por dois discos apostos. A. foliacea marginella apresentou espermátides no início do desenvolvimento com dois corpúsculos prata positivo (Figura 4i). Com o desenvolvimento, passaram a apresentar vários corpúsculos (Figura $4 \mathrm{j}$ ) e ao final desta fase $\mathrm{o}$ material foi observado ao redor do envoltório nuclear (Figura 4k). Nas espermátides elípticas, o material foi observado ao redor de todo envoltório nuclear (Figura 41). As espermátides alongadas apresentaram material prata positivo ao longo da cabeça na região mediana (Figura $4 \mathrm{~m}$ ).

\section{Discussão}

Uma das características pouco estudada em Heteroptera é o número de lobos que formam os testículos, assim como a membrana que os recobre. As espécies de Coreidae analisadas no presente trabalho apresentaram 7 lobos e membrana alaranjada ou avermelhada e a espécie de Alydidae apresentou 6 lobos e membrana vermelha.

Os testículos dos Heteroptera são formados por números variáveis de lobos, tendo sido encontrados sete lobos em espécies das famílias Coreidae (Anasa bellator, Athaumastus haematicus, Catorhintha gultula, 
Dallacoris obscura, D. pictus, Hypselonotus fulvus, Leptoglossus gonagra, L. zonatus e Sphictyrtus fasciatus) (SOUZA et al., 2007a, 2009), Alydidae (Hyalymus sp., SOUZA et al., 2009) e Rhopalidae (Niesthrea sidae, SOUZA et al., 2009), seis lobos em espécies das famílias Pentatomidae (Antiteuchus tripterus, SOUZA et al., 2007b), cinco lobos na família Alydidae (Neomogalotomus pallescens, SOUZA et al., 2009), quatro lobos em espécies da famílias Pentatomidae (Oebalus poecilus e O. ypsilongriseus, SOUZA et al., 2008) e Coreidae (Chariesterus armatus e Zicca annulata, SOUZA et al., 2007a), três lobos em espécies da família Pentatomidae (Mormidae quinqueluteum, SOUZA et al., 2008) ou dois lobos em Limnogonus aduncus (Gerridae, CASTANHOLE et al., 2008).

Como podemos observar as espécies de Coreidae (A. hahni, A. sp. e A. foliacea marginella) analisadas no presente trabalho apresentaram número de lobos (7) semelhantes às da maioria das espécies descritas na literatura. A única espécie de Alydidae (S. (Oryzocoris) furcifera) analisada no presente trabalho apresentou número de lobos (6) diferente da única espécie (Hyalymenus sp.) descrita na literatura (7). Portanto, pelo fato da maioria das espécies apresentarem sete lobos testiculares e considerando o princípio da parcimônia, o número sete deve ser o ancestral, mas devido à escassez de informações na literatura referente a essa característica, um maior número de espécies deverão ser analisadas, principalmente em relação à família Alydidae em que as informações são ainda mais restritas.

Os Coreidae, assim como a maioria dos Heteroptera, previamente descritos na literatura, apresentam cromossomos holocêntricos com atividade cinética na região telomérica, sistema cromossômico do sexo X0, geralmente, um quiasma intersticial ou terminal em cada autossomo (BRESSA et al., 2001, UESHIMA, 1979; MANNA, 1984; PAPESCHI; MOLA, 1990; WILSON, 1905; SOUZA et al., 2007a). As espécies de Coreidae e Alydidae analisadas no presente trabalho, também, apresentaram este mesmo padrão. 
As espécies de Coreidae analisadas no presente trabalho apresentaram 19 (Acanonicus hahni), 21 (Acantocephala sp) e 27 (Anisoscelis foliacea marginella) cromossomos, portanto somente $A$. sp. apresenta o número cromossômico ancestral da família como sugerido na literatura, pelo fato da maioria das espécies de Coreidae, descrita na literatura, apresentar número diplóide de 21 cromossomos $(18 \mathrm{~A}+2 \mathrm{~m}+\mathrm{X} 0)$ (aproximadamente $48 \%$ das 100 espécies já analisadas) (UESHIMA, 1979; SANDS, 1982; MANNA, 1984; COLOMBO; BIDAU, 1985; DEY; WANGDI, 1988; SATAPATHY; PATNAIK, 1989; CATTANI et al., 2004; SOUZA et al., 2007a). Uma outra característica que todas as espécies analisadas no presente trabalho apresentaram foi o sistema cromossômico do sexo X0. Esse sistema também foi identificado em todas as espécies descritas na literatura. Uma diferença observada e que não é comum para a família Coreidae é a ausência de m-cromossomos que foi observada em $A$. hahni. Esta espécie, cromossômicamente, é mais semelhante com as de Alydidae, já que a revisão da literatura nos mostra um complemento cromossômico de $2 \mathrm{n}=$ $13(10 \mathrm{~A}+2 \mathrm{~m}+\mathrm{X} 0)$, confirmada pela espécie analisada no presente trabalho.

$\mathrm{Na}$ literatura, discute-se a origem dos complementos cromossômicos constituídos de maior número de cromossomos a partir do menor número por duplicação ou fragmentação de um dos pares de autossomos (UESHIMA, 1980). Segundo Jacobs (2004), pelo fato dos Heteroptera apresentarem cromossomos holocêntricos, a fragmentação é o processo mais provável, porque origina segmentos que podem migrar regularmente para os pólos durante a anáfase e sobreviver por muitas gerações celulares. Da mesma maneira, a fusão cromossômica é também teoricamente mais fácil em organismos com cromossomos holocêntricos, segundo o mesmo autor.

Seguindo esse raciocínio, as espécies $A$. foliacea marginella e $A$. hahni com 27 e 19 cromossomos, respectivamente, poderiam ter se originado de uma espécie ancestral constituída de 21 cromossomos por fragmentação de autossomos e a espécie com número inferior por fusão cromossômica. A confirmação requer a utilização de outras técnicas. Com relação à espécie de 
Alydidae S. (Oryzocoris) furcifera o número diplóide de cromossomos $(2 \mathrm{n}=13)$ foi semelhante às poucas espécies descritas na literatura.

Nos artrópodes, é usual a dissociação do nucléolo no diplóteno ou diacinese, o que faz com que o mesmo não possa ser detectado entre a metáfase e a telófase. Nesse período, porém, em alguns organismos é possível detectar a localização das regiões organizadoras nucleolares. Estas são as regiões cromossômicas onde se aloja o DNA ribossômico responsável pela síntese do RNAr, cujas proteínas permanecem coradas com íons prata. Também é usual que quando as espermátides começam a se formar, os corpúsculos nucleolares reaparecem, desaparecendo, novamente, no final da formação dessas células reprodutivas (BRESSA et al., 2003).

Nos Heteroptera, têm sido detectadas situações diferentes da descrita, em que, no final da prófase e na metáfase meiótica, o material prata positivo continua a ser visível. Este é o caso de Antiteuchus tripterus (Pentatomidae), que mostra material nucleolar nas referidas fases, associado ou em torno da bainha pericromossômica, sendo que, no início da telófase o corpúsculo nucleolar se recompõe (SOUZA et al., 2007b). Em testículo de Nysius californicus (Lygaeidae), verificou-se a presença de material prata positivo desde a célula cística até o espermatozóide completamente diferenciado (SOUZA et al., 2007c). Em Triatoma brasiliensis e T. sordida (Reduviidae), corpúsculos corados com Ag-NOR permanecem observáveis até a metáfase I (TAVARES, AZEREDO-OLIVEIRA, 1997). No Coreidae, Carlisis wahlbergi, Fossey e Liebenberg (1995) observaram esses corpúsculos até a metáfase II.

Nas espécies analisadas no presente trabalho, o material prata positivo foi observado somente na região da bainha pericromossômica, com exceção de $A$. hahni em que observou-se marcação da RON em um autossomo, na região telomérica. A marcação da RON é extremamente difícil em cromossomos holocêntricos devido ao alto grau de condensação dos mesmos, tendo sido descrita em poucas espécies nos autossomos e cromossomos sexuais (CAMACHO et al., 1985; FOSSEY; LIEBENBERG, 1995; CASTANHOLE et al., 2008). 
As análises permitiram visualizar que há muitas características que são comuns para os Heteroptera e que as espécies das famílias Alydidae e Coreidae são muito semelhantes, principalmente se levarmos em consideração que elas possuem o mesmo sistema cromossômico de sexo (X0) e se compararmos $\mathrm{S}$. (Oryzocoris) furcifera e A. hahni, veremos que elas possuem uma outra característica em comum que é a de não possuir m-cromossomos. Outras técnicas, como por exemplo moleculares, completam os dados aqui apresentados para melhor caracterizar a filogenia do grupo.

\section{Agradecimentos}

À Dra. Sônia Maria Oliani do Laboratório de Morfologia, IBILCE/UNESP por permitir utilizar o microscópio para capturar as imagens, ao Dr. José Antônio Marin Fernandes da Universidade Federal do Pará, PA e ao Dr. Hélcio Gil Santana do Instituto Oswaldo Cruz, RJ pela identificação dos insetos, a CAPES, FAPESP e FUNDUNESP pelo apoio financeiro.

\section{Referências}

BRESSA, M.J.; PAPESCHI, A.G., MOLA, L.; LARRAMENDY, M.L. Autossomal univalents as a common meiotic feature in Jadera haematoloma and Jadera sanguinolenta (Heteroptera: Rhopalidae: Serinethinae). European Journal of Entomology, v. 98, p. 151-157, 2001.

BRESSA, M.J.; PAPESCHI, A.G.; FUMAGALLI, E.; VAN DOESBURG, P.H.; LARRAMENDY, M.L. Cytogenetic and nucleolar meiotic cycle analyses in Dysdercus imitator Blõte, 1931 (Pyrrhocoridae, Heteroptera) from Argentina. Folia Biologica (Krakow), v. 51, p. 135-141, 2003.

CAMACHO, J.P.M.; BELDA, J.; CABRERO, J. Meiotic behaviour of the holocentric chromosomes of Nezera viridula (Insecta, Heteroptera) analyzed Cbanding and silver impregnation. Canc. J. Gent Cytol, v. 27, p. 490-497, 1985. 
CASTANHOLE, M.M.U.; PEREIRA, L.L.V.; SOUZA, H.V.; BICUDO, H.E.M.C.; COSTA L.A.A.; ITOYAMA, M.M. Heteropicnotic chromatin and nucleolar activity in meiosis and spermiogenesis of Limnogonus aduncus (Heteroptera, Gerridae): a stained nucleolar organizing region that can serve as a model for studying chromosome behavior, Genetics and Molecular Research, v. 7, n. 4, p. 1398-1407, 2008.

CATTANI M.V.; PAPESCHI A.G. Nucleolus organizing regions and semipersistent nucleolus during meiosis in Spartocerca fusca (Coreidae, Heteroptera), Hereditas, v. 140, p. 105-111, 2004.

CATTANI, M.V.; GREIZERSTEIN, E.J.; PAPESCHI, A.G. Male meiotic behaviour and nucleolus organizer regions in Camptischium clavipes (Fabr.) (Coreidae, Heteroptera) analyzed by florescent banding and in situ hybridization. Caryologia, v. 57, n. 3, p. 267-273, 2004.

COLOMBO P.C.; BIDAU C.J. Estudios cromosómicos en heterópteros argentinos. I. Los cromosomas meióticos de cinco especies de Coreidae. Physis, v.43, p. 29-40, 1985.

DA CUNHA MARQUES, A.X. (Variously cited as Marques A.X. and XAVIER A. da C.M. - Cariologia comparada de alguns Hemípteros Heterópteros (Pentatomideos e coreideos). Mems. Estud. Mus. Zool. Univ. Coimbra, v. 163, p. 1-116, 1945.

DEY, S. K.; WANGDI, T. Chromosome number and sex chromosome system in forty-four species of Heteroptera. Chromosome Inf. Serv, v. 45, p. 5-8, 1988.

FOSSEY, A.; LIEBENBERG, H. Meiosis and nucleolar structures in the stink bug Cartisis wahlbergi Stal (Coreidae: Heteroptera) Cytobios, v.81, p. 7-15, 1995.

FROESCHNER, R. C. Family Alydidae Amyot and Serville, 1843. Pp. 4-11 in T. J. Henry and R. C. Froeschner [eds.], Catalog of the Heteroptera, or True Bugs, of Canada and the Continental United States. E. J. Brill, London, U. K. 658 pp. 1988.

GONZÁLEZ-GARCIA, J.M.; ANTONIO, C.; SUJA, J.A.; RUFAS, J.S. Meiosis in holocentric chromosomes: kinetic activity is randomly restricted to the 
chromatid ends of sex univalents in Graphosoma italicum (Heteroptera).

Chromosome Research, v. 4, p. 124-132, 1996.

HOWELL W.M.; BLACK, D.A. Controlled silver-staining of nucleolus organizer regions with a protective colloidal developer: a 1-step method. Experientia, v. 36, p. 1014-1015, 1980.

JACOBS, D.H. The evolution of a neo-XY1Y2 sex chromosome system by autosome sex chromosome fusion in Dundocoris nodulicarius Jacobs (Heteroptera: Aradidae: Carventinae). Chromosome Research, v. 12, p. 175-191, 2004.

LESTON, D. Results from the Danish expedition to the French Cameroons 194950. IX. Hemiptera, Pentatomoidea. Bulletin de I'Institut Français d'Afrique Noire (A). v. 18, p, 618-626, 1956.

MANNA, G. K. A study of the chromosomes during meiosis in forty-three species of Indian Heteroptera. Proc. Zool. Soc., Bengal, v. 4, p. 1-116, 1951.

MANNA, G.K. Chromosomes in evolution in Heteroptera. In: SHARMA, A.K., ed. Chromosomes in evolution of Eukaryotic groups. Boca Ratton Florida USA: CRCPress, p. 189-225, 1984.

PAPESCHI, A.G.; MOLA, L.M. Meiotic studies in Acanonicus hahni (Coreidae, Heteroptera). I. Behaviour of univalents in desynaptic individuals. Genetica, v. 80, p. 31-38, 1990.

PAPESCHI, A.G; BRESSA, M.J. Cytogenetic studies in Belostomatidae from Argentina. Abstracts of the second quadrennial meeting of the International Heteropteristis Society, v. 46, 2002.

PAPESCHI, A.G.; MOLA, L.M.; BRESSA, M.J.; GREIZERSTEIN, E.J.; LÍA, V.; POGGIO, L. Behaviour of ring bivalents in holocentric systems: Alternative sites of spindle attachment in Pachylis argentinus and Nezara viridula (Heteroptera). Chromosome Research, v. 11, p. 725-733, 2003. 
REBAGLIATI, P.J.; PAPESCHI, A.G.; MOLA, L.M. Meiosis and fluorescent banding in Edessa meditabunda and E. rufomarginata (Heteroptera:

Pentatomidae: Edessinae). European of Journal Entomology, v. 100, p. 11-18, 2003.

SANDS, V. E. Cytological studies of the Coreidae and Alydidae (Hemiptera: Heteroptera). II. Karyological changes exemplified by Malaysian genera. Caryologia, v.35, p.335-345, 1982.

SATAPATHY, S. N.; PATNAIK, S. C. Chromosome numbers in fourty-one species of Indian Heteroptera. Chromosome Inf. Serv, v. 47, p. 3-5, 1989.

SCHUH, T. T.; SLATER, J.A. The bugs of the world (Hemiptera: Heteroptera) Classification and natural history. Cornell UNIVERSITY press, 1995.

SOUZA, H.V.; ARAKAKI, R.L.M.; DIAS, L.; MURAKAMI, A.S.; COSTA, L.A.A.; BICUDO, H.E.M.C.; ITOYAMA, M.M. Cytogenetical Aspects of Testicular Cells in Economically Important Species of Coreidae Family (Heteroptera). Cytologia, v. 72, p. 49-56, 2007a.

SOUZA, H. V.; BICUDO, H. E. M. C.; COSTA L. A. A.; ITOYAMA, M. M. A study of meiosis and spermiogenesis in the testicular lobes of Antiteuchus tripterus (Heteroptera, Pentatomidae). European Journal of Entomology, v. 104, p. 353-362, 2007 b.

SOUZA, H.V.; BICUDO, H. E. M. C.; ITOYAMA, M.M. Study of chromosomal and nucleolar aspects in testes of Nysius californicus (Heteroptera: Lygaeidae). Genetics and Molecular Research, v. 6, n. 1, p. 33-40, 2007c.

SOUZA, H. V.; CASTANHOLE, M. M. U.; BICUDO, H. E. M. C.; COSTA L. A. A.; ITOYAMA, M. M. Morphological patterns of the heteropycnotic chromatin and nucleolar material in meiosis and spermiogenesis of some Pentatomidae (Heteroptera). Genetics and Molecular Biology, v. 31, n. 3, p. 686691, 2008. 
seminiferous tubules of Alydidae, Coreidae and Rhopalidae (Heteroptera) species. Genetics and Molecular Research, v. 8, n. 4, p. 1383-1396, 2009.

TAVARES, M. G.; AZEREDO-OLIVEIRA, M.J.V. Pattern of nucleolar activity during spermatogenesis in triatomines (Heteroptera: Reduvidae) as analysed by silver staining. Cytobios, v. 89, p. 93-103, 1997.

UESHIMA, N. Animal cytogenetics, Insecta 6, Hemiptera: Heteroptera. Gebruder Borntraeger: Berlin, Stuttgart, 1979.

UESHIMA, N.; Ashlock P.D. Cytotaxonomy of the Lygaeidae (Heteroptera). Univ. Kans. Sci. Bull., v 51, p. 717-801, 1980.

WILSON, E.B. Studies of chromosomes II. The paired microchromosomes, idiochromosomes and heterotropic chromosomes in Hemiptera. The Journal of Experimental Zoology, v. 2, p. 507-545, 1905. 

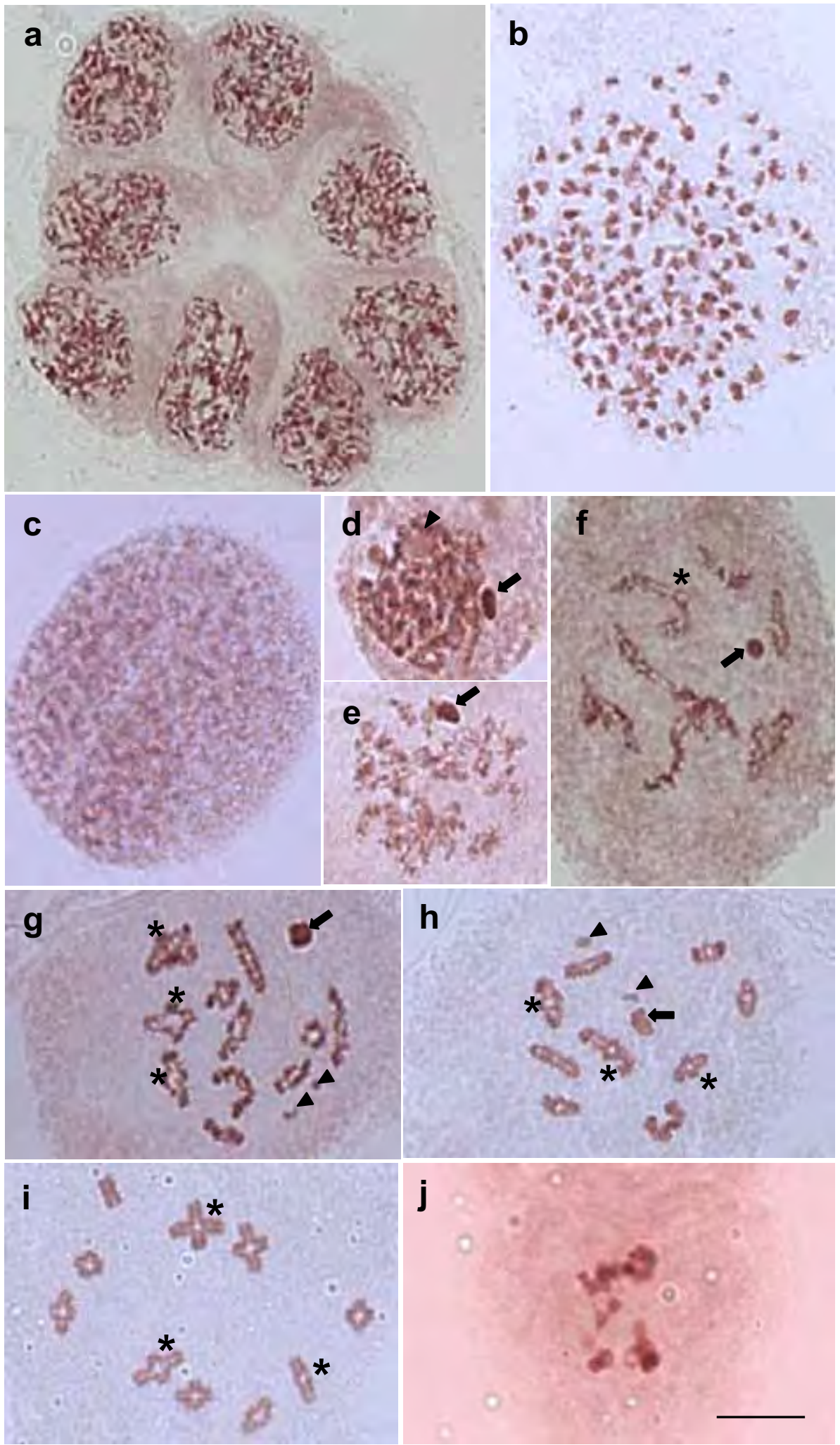

Figura 1. Células dos túbulos seminíferos de Stenocoris (Oryzocoris) furcifera (c, f, j) (Alydidae), Acanonicus hahni (a, i), Acantocephala sp (b, h) e Anisoscelis foliacea marginella (d, e, g) (Coreidae) coradas com orceína lacto-acética. a) cisto espermatogonial apresentando 8 espermatogônias; b,c) núcleos poliplóides; d) leptóteno com material heteropicnótico arredondado (seta) e uma estrutura não corada (cabeça de seta) que possivelmente é o nucléolo; e) zigóteno-paquíteno com material heteropicnótico (seta); f-i) diplóteno/diacinese mostrando o cromossomo sexual heteropicnótico (seta), os m-cromossomos (cabeça de seta) e alguns autossomos com quiasmas intersticiais (asteriscos); j) célula apresentando cromossomos unidos pela região telomérica, apresentando morfologia de "Z". Barra: $10 \mu \mathrm{m}$. 

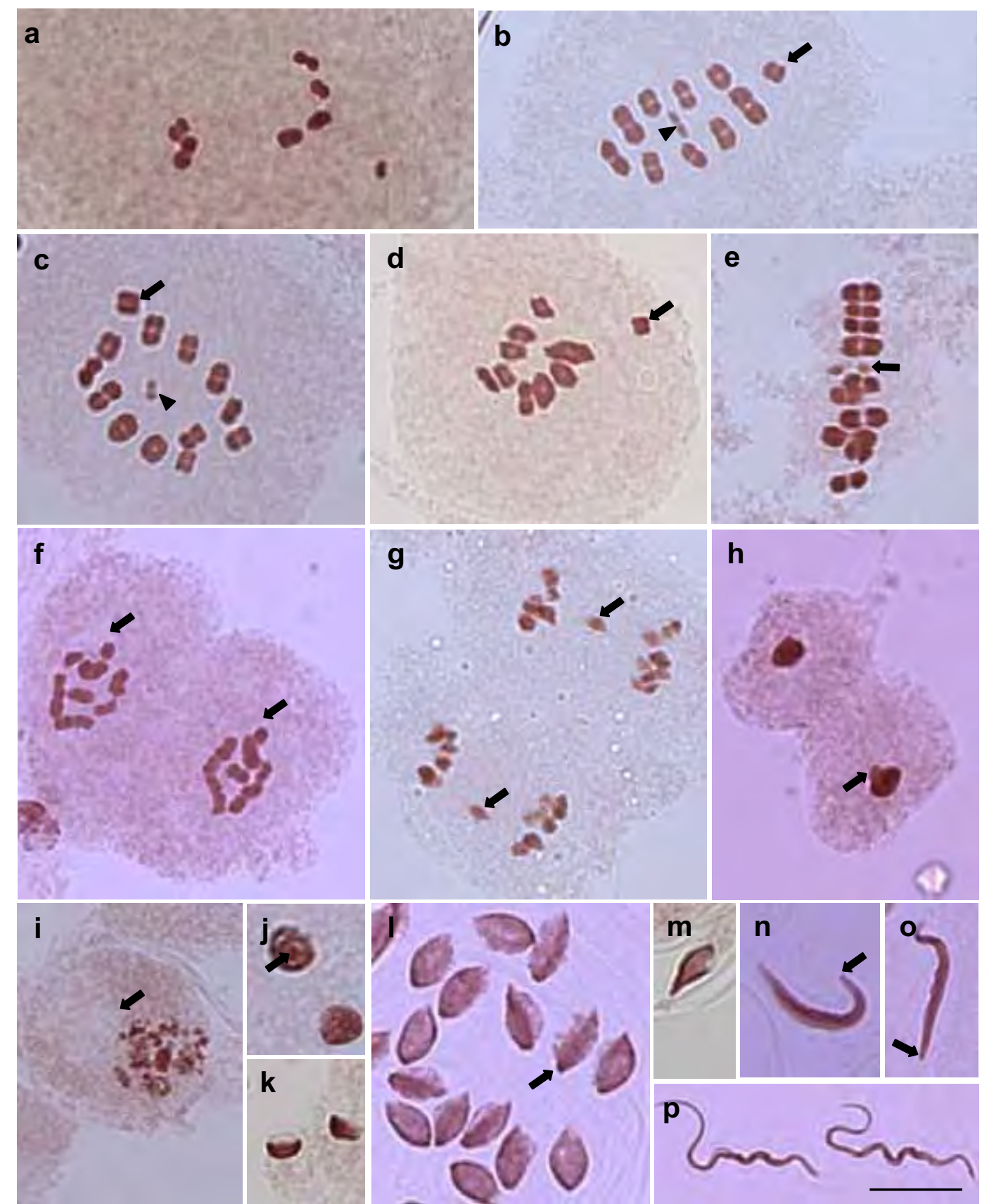

Figura 2. Células dos túbulos seminíferos de Stenocoris (Oryzocoris) furcifera (a, k, m) (Alydidae), Acanonicus hahni (d, f, g, h), Acantocephala sp $(\mathrm{b}, \mathrm{e})$ e Anisoscelis foliacea marginella $(\mathrm{c}, \mathrm{i}, \mathrm{j}, \mathrm{1}, \mathrm{n}, \mathrm{o}, \mathrm{p})$ (Coreidae) coradas com orceína lacto-acética. a-d) metáfases I de $S$. (Oryzocoris) furcifera com $2 \mathrm{n}=13(12 \mathrm{~A}+\mathrm{X} 0)(\mathrm{a}), A$. sp com $2 \mathrm{n}=21(18 \mathrm{~A}+2 \mathrm{~m}+\mathrm{X} 0)(\mathrm{b})$, A. foliacea marginella $\operatorname{com} 2 \mathrm{n}=27(24 \mathrm{~A}+2 \mathrm{~m}+\mathrm{X} 0)(\mathrm{c})$ e A. hahni com $2 \mathrm{n}=$ $19(18 \mathrm{~A}+\mathrm{X} 0)(\mathrm{d})$ cromossomos. As setas indicam os cromossomos X e as cabeças de seta o m-cromossomos. Observar que na metáfase I em visão polar os autossomos formam um anel e o cromossomo sexual fica fora dele (b-d); e) metáfase I de $A$. sp em visão lateral, a seta indica os cromossomos sexuais; f) início da telófase I com as duas células apresentando cromossomo sexual (setas); g) anáfase II com migracão tardia do cromossomo sexual (setas); h) telófase II podendo-se observar que apenas uma das células recebe o cromossomo sexual (seta); i) espermátide recém formada apresentando material heteropicnótico e uma vesícula grande (seta); j-k) espermátide arredondada com material heteropicnótico arredondado no centro (seta); 1-o) espermátides em alongamento com material heteropicnótico na região posterior da cabeça (setas); p) espermatozóides em formação. Barra: $10 \mu \mathrm{m}$. 

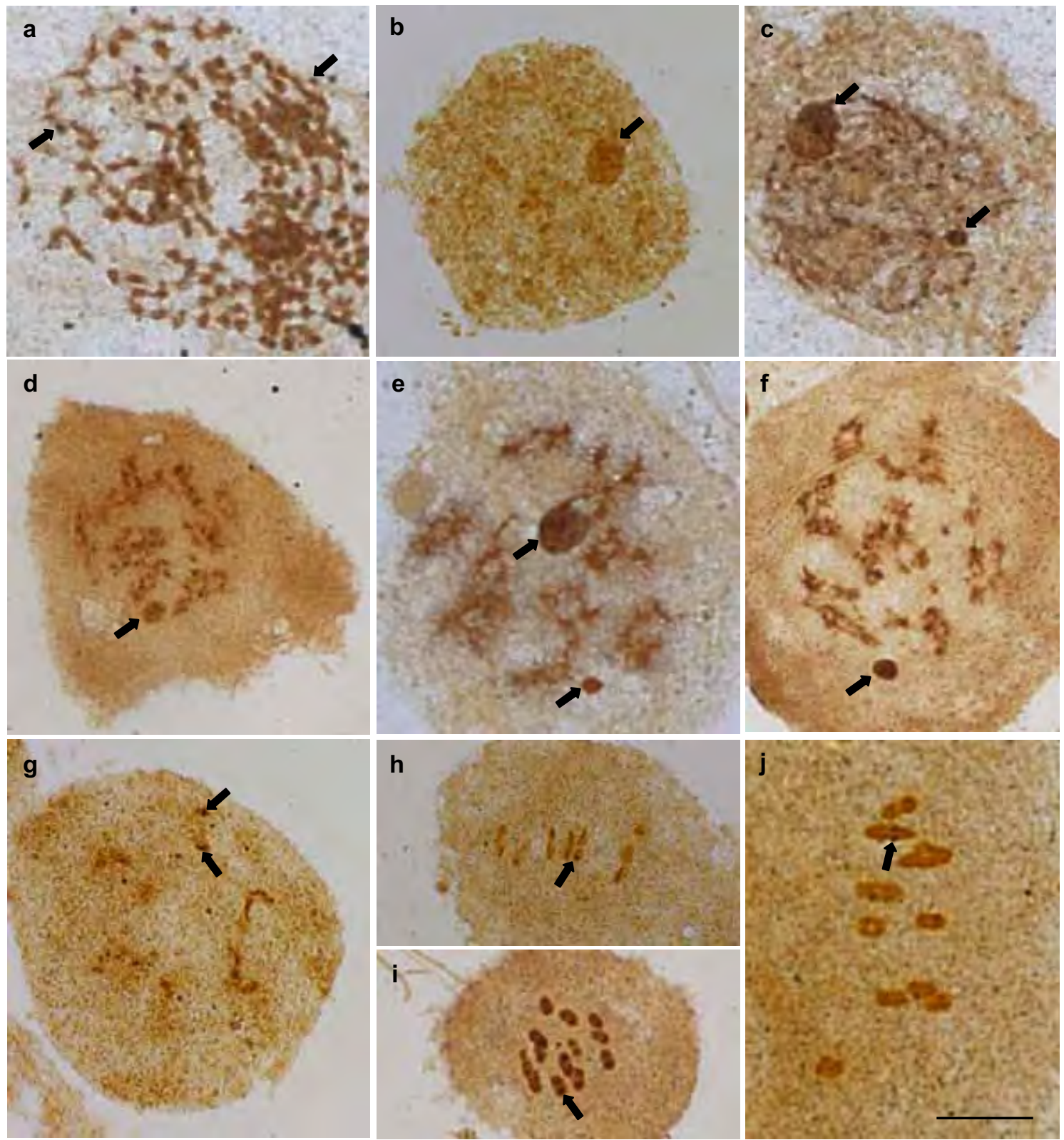

Figura 3. Células dos túbulos seminíferos de Stenocoris (Oryzocoris) furcifera (b, g, h) (Alydidae), Acanonicus hahni (a, c, e, j) e Anisoscelis foliacea marginella (d, f, i) (Coreidae) impregnadas por íons prata. a) núcleo poliplóide com algumas regiões impregnadas pelos íons prata (seta); b,c) leptóteno com uma ou duas marcações de tamanhos diferentes (setas); d,e) zigóteno/paquíteno com uma ou duas marcações de tamanhos diferentes (setas); f) diplóteno com uma marcação (seta); g) diacinese com algumas regiões da bainha cromossômica impregnadas pelos íons prata (setas); h-i) metáfases com algumas regiões da bainha marcadas (setas); j) metáfase com uma região que possivelmente é a da RON (seta). Barra: $10 \mu \mathrm{m}$ 

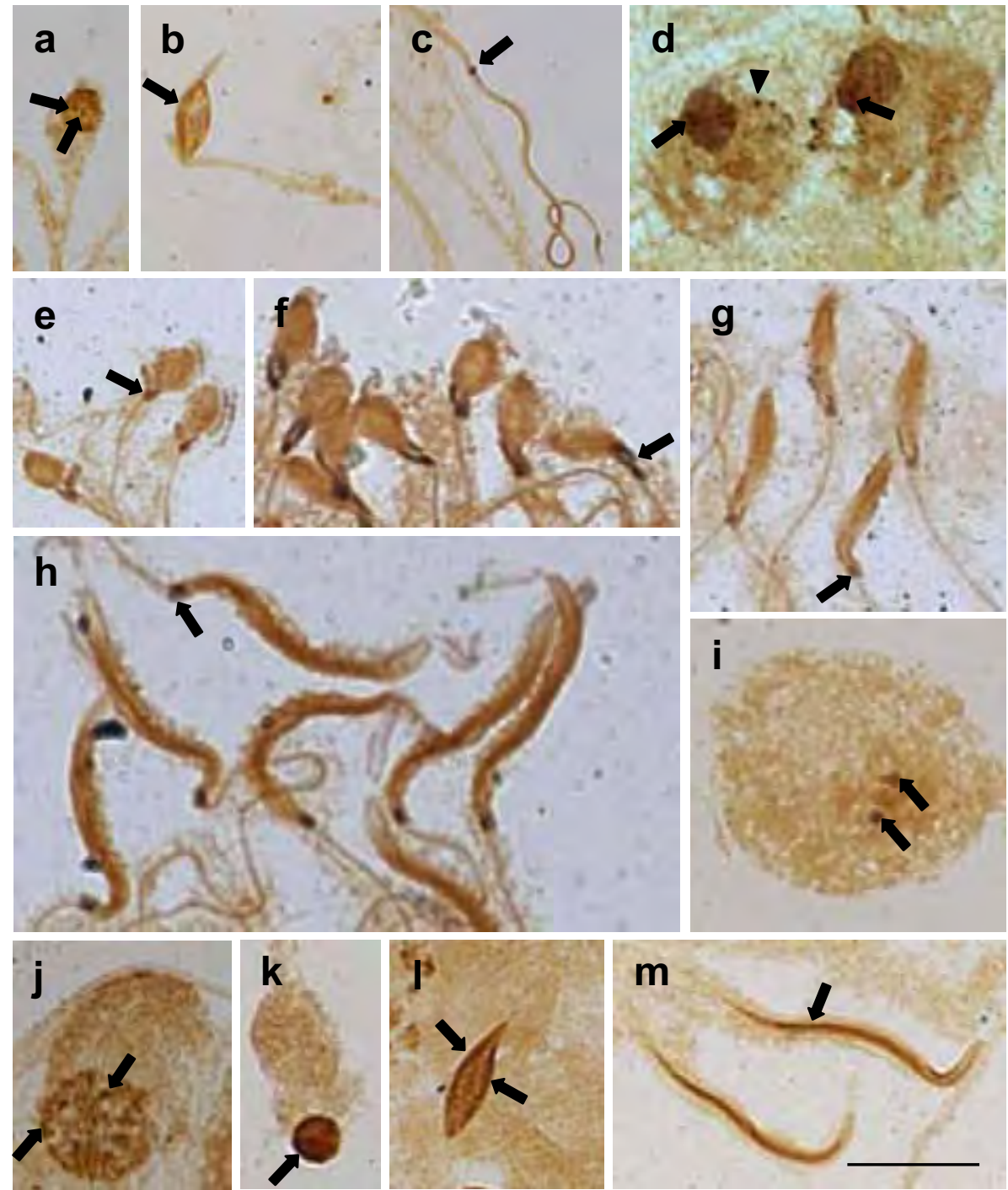

Figura 4. Células dos túbulos seminíferos de Stenocoris (Oryzocoris) furcifera (a-c) (Alydidae), Acanonicus hahni (d-h) e Anisoscelis foliacea marginella (i-m) (Coreidae) impregnadas por íons prata. a-c) espermiogênese de $S$. (Oryzocoris) furcifera; a) espermátide inicial com pequenos grânulos prata positivo (setas); b) espermátide elíptica com material prata positivo depositado em apenas um dos lados do núcleo (seta); c) espermátide alongada com apenas 1 marcação na região da cauda; d-h) espermiogênese de $A$. hahni; d) espermátide inicial com marcações no núcleo (seta) e algumas marcações na vesícula (cabeça de seta); e-h) espermátide elíptica com material prata positivo na região posterior da cabeça (setas). Observar em $\mathrm{f}$ que estas marcações são em forma de 2 discos; i-m) espermiogênese de $A$. foliacea marginella; i) espermátide inicial com 2 marcações prata positivo; j) espermátide em alongamento com várias marcações; k) espermátide com marcação ao redor do envoltório nuclear (seta); 1) espermátide elíptica com marcação ao longo da membrana da cabeça (seta); m) espermátide alongada com marcação ao longo da cabeça na região mediana (seta). Barra: $10 \mu \mathrm{m}$. 


\section{Caracterização dos lobos testiculares normais e harlequin de Chlorocoris complanatus e Loxa deducta (Heteroptera, Pentatomidae, Pentatominae)}

MURAKAMI, Aline Sumitani; ITOYAMA, Mary Massumi

UNESP-Universidade Estadual Paulista, Instituto de Biociências, Letras e Ciências Exatas, Departamento de Biologia, Laboratório de Citogenética e Molecular de Insetos-LACIMI

\section{Resumo}

A análise dos lobos testiculares de Chlorocoris complanatus e Loxa deducta (Heteroptera, Pentatomidae, Pentatominae) mostrou que ambas as espécies apresentam 7 lobos alongados envoltos por membrana amarelada na região proximal e transparente na distal, sendo o quinto o maior deles. $\mathrm{O}$ estudo individualizado dos lobos permitiu-nos verificar que o comportamento durante a espermatogênese dos lobos 1, 2, 3, 4, 6 e 7 são semelhantes e apresentam características já descritas para a maioria dos Heteroptera como, por exemplo, presença de um corpúsculo heteropicnótico na prófase, presença de quiasmas intersticiais ou terminais, divisão reducional dos autossomos na primeira divisão e o inverso com relação aos cromossomos sexuais. As células do lobo 5 em prófase são poliplóides, não se segregam regularmente na anáfase e formam de 3 tipos diferentes de espermatozóides (pequeno, médio e grande), características que confirmam que este lobo é o harlequin. A impregnação pela prata evidenciou a semi-persistência nucleolar em L. deducta, o que não foi observado em $C$. complanatus. As espermátides $\mathrm{P}, \mathrm{M}$ e $\mathrm{G}$ do lobo 5 apresentaram quantidade maior de corpúsculos prata positivo do que as dos outros lobos, indicando maior atividade sintética.

Palavras-chave: cromossomos holocêntricos, espermatogênese, espermátide, semi-persistência nucleolar 


\section{Introdução}

A família Pentatomidae é, em número de espécies, uma das maiores dentre os Heteroptera, sendo cosmopolita e com maior diversidade nos trópicos. Conta com aproximadamente 880 gêneros e 4.500 espécies (SCHUH; SLATER, 1995; SCHAEFER; PANIZZI, 2000). Esses insetos são conhecidos como "Marias-fedidas" devido à produção de um odor desagradável emitido pelos ductos das glândulas produtoras de cheiro, que se abrem na região da metapleura. Schuh e Slater (1995) incluiram oito subfamílias nesta família: Aphylinae, Asopinae, Cyrtocorinae, Discocephalinae, Edessinae, Pentatominae, Phyllocephalinae e Podopinae. Os fitófagos economicamente mais importantes são espécies pertencentes às subfamílias Edessinae e Pentatominae, e englobam a maioria das espécies que são pragas de grãos. As espécies pertencentes a Asopinae são predadoras, e algumas dessas são importantes agentes de controle biológico (SCHAEFER; PANIZZI, 2000).

Os testículos de todas as espécies de Pentatomidae consistem de um número de subdivisões, compartimentos ou lobos. O número mais comum de lobos é sete, embora haja variações entre tribos e espécies. As características dos espermatozóides (tamanho e/ou ploidia) diferem entre os lobos testiculares (SWALLOW; WILKINSON, 2002). Montgomery (1898 apud SCHRADER, 1960a) classificou, pela primeira vez, os espermatozóides do lobo 5 de Pentatomidae em três classes: grande, médio e pequeno.

Os Pentatomidae apresentam número diplóide de $2 \mathrm{n}=14$ cromossomos, sistema cromossômico do sexo XY/XX e não possuem mcromossomos. Entretanto, uma característica particular de algumas espécies é a presença de uma meiose anormal em um dos lobos testiculares, denominado de lobo harlequin (SCHRADER, 1945a,b, 1946a,b, 1960a,b; SOUZA et. al., 2007a).

Nos Pentatomidae uma única Região Organizadora Nucleolar (RON) foi detectada na região telomérica de um par de autossomos em Edessa meditabunda (REBAGLIATI et al., 2003), na posição mediana em um par de autossomos grande em Nezara viridula (CAMACHO et al., 1985; PAPESCHI et 
al., 2003) ou na região telomérica do cromossomo X de Graphosoma italicum (GONZALEZ-GARCIA et al., 1996).

Pelas características anteriormente citadas de presença ou não de lobo harlequin, formação de diferentes tipos de espermatozóides, número variável de cromossomos, diferentes sistemas cromossômicos do sexo, poucos trabalhos relacionados com a citogenética (comportamento meiótico e nucleolar), o objetivo do presente trabalho foi o de analisar a morfologia do testículo para verificar, especialmente, o número de lobos e a presença ou não do lobo harlequin; analisar detalhadamente a espermatogênese (comportamento meiótico e espermiogênese) e o comportamento nucleolar das espécies Chlorocoris complanatus e Loxa deducta (Pentatomidae).

\section{Materiais e Métodos}

Quinze machos adultos de cada espécie de Chlorocoris complanatus e Loxa deducta (Pentatomidae, Pentatominae) foram coletados no município de São José do Rio Preto-SP $\left(20^{\circ} 47^{\prime} 32^{\prime \prime S}, 4^{\circ} 21^{\prime} 37^{\prime \prime W}\right)$ em pés de pitanga (Eugenia uniflora). Após a coleta foram eterizados e dissecados, já que a espermatogênese em Heteroptera não se encerra no estágio de ninfa. Os testículos extraídos tiveram os lobos individualizados, colocados e dilacerados em lâminas, separadamente, e corados com orceína lacto-acética ou impregnados por íons prata segundo protocolo modificado de Howell e Black (1980), para o estudo citogenético da meiose e espermiogênese. As amostras que não foram utilizadas, logo após a coleta, foram fixadas em metanol:ácido-acético (3:1) e mantidas a $8^{\circ} \mathrm{C}$. As lâminas foram analisadas no microscópio de luz Olympus modelo BX40 do Laboratório de Citogenética e Molecular de Insetos e as melhores imagens foram capturadas no microscópio de luz AXIOSKOP 2 ZEISS (programa AXIOVISION) do laboratório de Morfologia, do Departamento de Biologia do IBILCE/UNESP, São José do Rio Preto - SP. 


\section{Resultados}

Observação das células após coloração com orceína lacto-acética

As espécies de Pentatomidae, Chlorocoris complanatus e Loxa deducta, tiveram os seus testículos dissecados e pode-se observar que ambos são formados por 7 lobos alongados, possuem membrana branca envolvendo-os e unindo-os há uma membrana amarelada na região proximal e transparente na distal. Morfologicamente, verificamos que as duas espécies possuem o lobo 5 maior que os demais.

Pelo fato de algumas espécies de Pentatomidae apresentarem lobo harlequin, os mesmos foram analisados separadamente. Após análise verificou-se que durante a espermatogênese os lobos 1,2, 3, 4, 6 e 7, de ambas as espécies, apresentaram resultados semelhantes e que diferiram do 5. Por esse motivo os resultados dos lobos 1, 2, 3, 4, 6 e 7 serão apresentados em conjunto, assim como as das duas espécies, por também terem apresentado comportamentos semelhantes.

A análise das células testiculares permitiu visualizar que o processo de espermatogênese ocorre nos cistos espermatogoniais e que o mesmo é constituído de 6 espermatogônias (Figura 1a). Uma outra observação realizada é a de que os núcleos poliplóides das células nutritivas, destes lobos, são constituídos por várias regiões heteropicnóticas de diferentes tamanhos (Figura 1b).

Durante a espermatogênese, observamos que as células meióticas em zigóteno-paquíteno apresentam apenas uma região heteropicnótica arredondada e fortemente corada, que possivelmente são os cromossomos sexuais (Figura 1c,d).

$\mathrm{Na}$ Figura 1e podemos observar uma célula em início do processo de condensação dos cromossomos, onde podemos visualizar a presença de um quiasma e uma região heteropicnótica evidente. Com o processo de condensação, os quiasmas tornam-se mais evidentes (Figura 1f). Na Figura $1 \mathrm{f}$ observa-se, também, a presença de um cromossomo com dois quiasmas terminais, 
que dá ao cromossomo a morfologia em anel. Os cromossomos metafásicos possuem associação telomérica e podem ser observados em visão polar (Figura 2a) ou lateral (Figura 2b). Nesta fase verificamos que o complemento cromossômico de $C$. complanatus e $L$. deducta é de $2 \mathrm{n}=14(12 \mathrm{~A}+\mathrm{XY})$ cromossomos e que o sistema cromossômico do sexo é o XY.

Durante a anáfase I (Figura 2c), observamos em cada grupo de cromossomos formados, a presença dos cromossomos $\mathrm{X}$ e $\mathrm{Y}$, isto porque em Heteroptera, a divisão dos cromossomos sexuais é o inverso do que ocorre com os autossomos, isto é, na primeira divisão meiótica separam-se as cromátides irmãs (divisão equacional) e, na segunda, separam-se os cromossomos homólogos (divisão reducional). Na metáfase II, podemos observar os cromossomos sexuais, $\mathrm{X}$ e $\mathrm{Y}$, formando um pseudobivalente (Figura 2d).

No final da telófase (Figura 2e), o material cromatínico está altamente condensado, formando posteriormente, espermátides com material cromatínico disperso e constituído de uma vesícula grande ao lado do núcleo (Figura 2f). Na continuidade do processo, a cromatina vai se condensando e há redução no tamanho da vesícula (Figura $2 \mathrm{~g}$ ).

No início do alongamento, as espermátides possuem forma elipsóide e apresentam material heteropicnótico ao redor de todo envoltório nuclear com exceção da região caudal (Figura 2h). As espermátides alongadas apresentam material heteropicnótico fortemente corado somente em um dos lados do envoltório nuclear (Figura 2i). Com o alongamento, o material heteropicnótico é visualizado ao longo da cabeça da espermátide (Figura 2j). Os espermatozóides em formação possuem cabeça pequena e cauda longa (Figura 2k).

Passaremos a descrever os resultados do lobo 5 das espécies $C$. complanatus e L. deducta, pois como mencionado anteriormente este lobo apresentou comportamento diferente dos outros lobos. Os resultados das duas espécies serão apresentados em conjunto pelo fato de ter sido verificado, também, que são semelhantes.

Os núcleos poliplóides das células nutritivas do lobo 5 são grandes e apresentam um corpúsculo heteropicnótico maior e vários pequenos 
(Figura 3a). Na prófase observa-se que as células sempre apresentam cromatina descondensada e várias regiões heteropicnóticas que varia de célula para célula e que sempre são maiores que as células dos lobos normais (Figura 3b). Não se observou, neste lobo, as fases intermediárias do processo de condensação dos cromossomos, assim como a formação de quiasmas. A outra fase do processo meiótico encontrado foi a metafásica em diferentes graus de condensação cromossômica (Figura 4a,b). Uma outra característica observada foi a presença de um número superior de cromossomos e de regiões heteropicnóticas, que foi variável de célula para célula (Figura 4c,d).

As anáfases encontradas apresentaram diferentes configurações e aspectos, como descritas a seguir: a) os cromossomos estavam altamente condensados, com morfologia bem definida (Figura 4c,d) ou descondensados podendo, apenas, visualizar com nitidez os corpúsculos heteropicnóticos (Figuras 5a-c); b) o número de células formadas varia de duas (Figuras 5a,c) até quatro (Figura 5b); c) a forma com que as células eram separadas, também são diferentes, uma única célula pode formar três, uma na seqüência da outra (Figura 4c) ou três interligadas (Figura 4d); d) uma outra característica é que sempre há material cromatínico na região de separação das células (Figuras 4d, 5a-c).

Observamos, também, que a quantidade de material genético que cada célula recebe é diferente e que esta característica é independente se os cromossomos estão condensados (Figura 4c,d) ou descondensados (Figura 5a-c). Quando os cromossomos estão descondensados, é possível verificar que há algumas células que não recebem material heteropicnótico (Figura 5b,c). No lobo 5 observamos, ainda, células em anáfase na sua forma "tradicional" com os cromossomos/cromátides separando na placa equatorial da célula (Figura 5d,e), assim como migração tardia de cromossomos (Figura 5e).

A espermiogênese inicia-se com espermátides arredondadas, apresentando 3 diferentes tamanhos: pequena $(\mathrm{P})$, média $(\mathrm{M})$ e grande $(\mathrm{G})$ (Figura 5f). Nestas células o material cromatínico não se distribui por toda célula, estando restrita a, aproximadamente, $50 \%$ da célula. Nas espermátides em alongamento observamos também os 3 tamanhos e o material cromatínico também não se 
distribui por toda célula, estando mais na região anterior da cabeça (Figura 5g). Essa distribuição persiste nas espermátides em alongamento (Figura 5h).

\section{Observação das células após impregnação por ions prata}

Para análise da espermatogênese após impregnação por íons prata, os lobos também foram isolados e analisados separadamente, chegando-se a conclusão de que o comportamento é semelhante para todos, exceto para o lobo 5. Desta forma os dados de todos os lobos, exceto o 5, foram agrupados, assim como, os dados das espécies $C$. complanatus e $L$. deducta que também foram semelhantes.

Os lobos 1, 2, 3, 4, 6 e 7, das duas espécies, apresentaram, no início da prófase algumas marcações arredondadas (Figura 6a). Com a condensação dos cromossomos as marcações começaram a ficar mais evidentes. Elas apresentam 1 (Figura 6b) ou 3 (Figura 6c) corpúsculos corados, sendo o menor arredondado e mais impregnado e os 2 maiores, sem morfologia muito definida (Figura 6d,e). Com a condensação dos cromossomos observa-se que estes corpúsculos prata positivo estão associados aos autossomos (Figura 6f-h). Durante a metáfase, das duas espécies, não foi possível observar a região organizadora nucleolar (RON) (Figura 7a,b). Na metáfase e anáfase de L. deducta observou-se semi-persistência nucleolar (Figura 7b,c).

As espermátides de C. complanatus apresentaram 3 corpúsculos prata positivo (Figura 7d). Numa fase posterior, observa-se um maior e outro menor (Figura 7e) e na fase subsequente uma única marcação arredondada, fortemente impregnada e deslocada para a periferia da cabeça da espermátide (Figura 7f). A espermátide elipsóide possui marcação arredondada e alongada na parte posterior da cabeça e em apenas um dos lados da espermátide (Figura $7 \mathrm{~g}$ ). Com o alongamento, só permaneceram as marcações ao longo da cabeça e ao longo da cauda (Figura 7h-k). As espermátides de L. deducta apresentaram 2 corpúsculos prata positivo (Figura 71). No início do alongamento, observa-se apenas 1 marcação arredondada em uma das extremidades e em um dos lados da 
membrana do núcleo (Figura $7 \mathrm{~m}$ ). As espermátides elipsóides mostraram 2 corpúsculos: um na região mediana da espermátide e outra na posterior (Figura 7n). Com o alongamento as marcações não são mais observadas (Figura 7o-r).

Como mencionado anteriormente, as células do lobo 5 apresentaram comportamentos diferentes. Algumas células em prófase apresentaram várias marcações com fraca impregnação (Figura 8a) ou com nucléolos de vários tamanhos arredondados e fortemente impregnados (Figura 8b) ou com várias marcações pequenas (Figura 8c). As metáfases de C. complanatus não apresentaram nenhuma marcação (Figura $8 \mathrm{~d}$,e). Já as metáfases/anáfases de $L$. deducta sempre apresentaram corpúsculos nucleolares e algumas regiões da bainha pericromossômica marcadas (Figura 8f-h).

As células em anáfase apresentaram números variáveis de corpúsculos nucleolares. Nas células em que a cromatina não estava condensada, havia um ou mais corpúsculos em cada célula que estava sendo formada (Figura 9a,b), mas com cromossomos condensados observou-se um corpúsculo prata positivo (Figura 9c). Durante a espermiogênese de L. deducta, não observou-se nenhum material prata positivo em nenhuma das espermátides: pequena $(\mathrm{P})$, média (M) e grande (G) (Figura 10a-d). Diferentemente de L. deducta, $C$. complanatus apresentou espermátides arredondadas G e M com 5 corpúsculos maiores e vários menores (Figura 10e,i, G,M) e a P com 2 (Figura 10m). Esses corpúsculos foram migrando para a região posterior da cabeça das espermátides $\mathrm{G}$ (Figura 10e-h), M (Figura 10i-1) e P (Figura 10m-p) em início de alongamento. O processo final de alongamento das espermátides $\mathrm{P}, \mathrm{M}$ e $\mathrm{G}$ foram semelhantes, isto é, observou-se o material prata positivo alongado na região posterior da cabeça da espermátide (Figura 10q-s). A Figura 10t,u mostra uma fase mais avançada do alongamento das espermátides. Algumas espermátides apresentaram regiões de fragmentação (Figura 10u). 


\section{Discussão}

Os testículos dos Heteroptera são formados por números variáveis de lobos e recobertos por membrana de diferentes colorações. Antiteuchus tripterus (Pentatomidae, Discocephalinae) possui testículo recoberto por membrana avermelhada e é constituído de seis lobos testiculares alongados, sendo o sexto interno ao quinto (SOUZA et al., 2007a). Mormidea quinqueluteum, Oebalus poecilus e Oebalus ypsilongriseus (Pentatomidae, Pentatominae) possuem, também, membrana avermelhada recobrindo o testículo, mas o número de lobos encontrado foi de três, quatro e quatro, respectivamente (SOUZA et al., 2008).

Segundo revisão realizada por Souza et al. (2009) há descrito, na literatura, informações de 51 espécies relacionadas ao número de lobos, meiose atípica e polimegalia. Os dados referem-se às subfamílias Asopinae, Acanthosomatinae, Discocephalinae, Edessinae e Pentatominae. As espécies da subfamílias Asopinae e Acanthosomatinae apresentaram seis ou sete lobos e meiose normal, as espécies das demais subfamílias apresentaram de três a oito lobos testiculares e algumas espécies com meiose atípica. As espécies Chlorocoris complanatus (Pentatomidae, Pentatominae) e Loxa deducta (Pentatomidae, Pentatominae), analisadas no presente trabalho, apresentaram sete lobos. Verificase, portanto, que não há um número de lobos padrão para as subfamílias. Portanto, não há, aparentemente, correlação entre esta característica e a subfamília, necessitando de aprofundamento das análises.

Algumas espécies da família Pentatomidae além de apresentarem números variáveis de lobos testiculares podem ou não apresentar um lobo diferenciado denominado harlequin. Dos quinze gêneros estudados com a presença do lobo harlequin em Pentatomidae, 11 pertencem a subfamília Discocephalinae, 3 pertencem a Pentatominae e 1 pertence a Edessinae (REBAGLIATI et al., 2005). Portanto, das oito subfamílias existentes (Aphylinae, Asopinae, Cyrtocorinae, Discocephalinae, Edessinae, Pentatominae, 
Phyllocephalinae e Podopinae) segundo Schuh e Slater (1995) somente três (Discocephalinae, Edessinae e Pentatominae) possuem este lobo. As duas espécies analisadas no presente trabalho, pertencentes à subfamília Pentatominae, também apresentaram o lobo harlequin, mantendo, portanto, a característica para a subfamília.

Segundo Schrader (1945a,b; 1946a,b), o lobo harlequin não possui ocorrência acidental ou esporádica nas espécies possuidoras. Eles são encontrados em todos os testículos e em todos os machos de uma dada espécie e é sempre o mesmo lobo. Em Discocephalinae, por exemplo, geralmente é o lobo 5, contado a partir do ducto ejaculatório, o harlequin. A espécie Antiteuchus tripterus (Heteroptera, Pentatomidae, Discocephalinae), analisada por Souza et al. (2007a), também apresenta seis lobos testiculares, sendo o 5 o harlequin.

As espécies analisadas no presente trabalho apresentam sete lobos sendo, também, o 5 o harlequin. Portanto, parece que todas as espécies que apresentam lobo harlequin, este sempre é o quinto. Uma outra característica observada nos lobos harlequin, é que o comportamento das células também diferem, principalmente durante a metáfase/anáfase. Nestas fases, os cromossomos podem ser visualizados condensados ou descondensados, como as espécies analisadas neste trabalho, diferentemente de Antiteuchus tripterus (SOUZA et al., 2007a) onde só foi visualizado cromossomos descondensados.

Com relação à impregnação por prata, as espécies analisadas no presente trabalho, somente $L$. deducta apresentou semi-persistência nucleolar, isto é, o material prata positivo foi observado durante as metáfases e anáfases. Segundo a literatura, o comportamento do material nucleolar durante a espermatogênese varia entre os organismos. Por exemplo, em artrópodos, o material dissocia-se no diplóteno ou diacinese e, portanto, não são detectados pela técnica Ag-NOR da metáfase I até a telófase I. Corpúsculos nucleolares corados vão reaparecer no início da formação das espermátides, indicando o reinício das funções transcricionais de RNAr e desaparecem no final de sua formação (BRESSA et al., 2003). Entretanto, algumas espécies são exceções a esse padrão. 
Em Nysius californicus (Heteroptera, Lygaidae) verificou-se a presença de material nucleolar desde a célula cística até o espermatozóide completamente diferenciado, sugerindo a ocorrência de síntese protéica durante todo o processo de espermatogênese (SOUZA et al., 2007b). Em Triatoma brasiliensis e $T$. sordida (Heteroptera, Reduviidae), corpúsculos corados com Ag-NOR permaneceram observáveis até a metáfase I (TAVARES; AZEREDO-OLIVEIRA, 1997). Em Carlisis wahlbergi (Heteroptera, Coreidae), corpúsculos nucleolares foram observados até a metáfase II (FOSSEY; LIEBENBERG, 1995), enquanto em Acanthocoris sordidus (Heteroptera, Coreidae) e Coptosoma punctissimum (Heteroptera, Plataspidae) os nucléolos foram detectados nas placas metafásicas de espermatócitos primários e secundários (YOSHIDA, 1947). As espécies Mormidae quinqueluteum, Oebalus poecillus e O. ypsilongriseus (Pentatomidae) apresentaram semi-persistência nucleolar (SOUZA et al., 2008).

Com relação às proteínas que ficam localizadas nas regiões das RONs, ainda há poucas espécies de Heteroptera descritas por diferentes técnicas citogenéticas. As poucas espécies que foram descritas apresentaram uma única RON localizada na posição média ou subterminal de um autossomos ou de um cromossomo sexual (CAMACHO et al., 1985; FOSSEY; LIEBENBERG, 1995; GONZÁLEZ-GARCIA et al., 1996; PAPESCHI e BRESSA, 2002; PAPESCHI et al., 2003; CATTANI et al., 2004). Nas espécies analisadas no presente trabalho não foi possível determinar em qual cromossomo está localizado a RON. Sabemos que a identificação das regiões de RON são dificultadas pelas características holocêntrica, tamanho reduzido e/ou condensação acentuada dos cromossomos desses insetos.

O comportamento nucleolar durante a espermiogênese foi diferente entre as espécies analisadas, em C. complanatus o material foi observado até o final da prófase e em L. deducta foi observado semi-persistência nucleolar durante a metáfase $\mathrm{e}$ anáfase. Trabalhos relacionados com o comportamento das células durante a espermiogênese após impregnação por íons prata são raros. Foi observado, por exemplo, em espécies de Panstrongylus 
(Heteroptera) que as marcações são visualizadas somente até a espermátide inicial (arredondada), desaparecendo durante a sua elongação (TARTAROTTI; AZEREDO-OLIVEIRA, 1999). Esse processo foi observado também em mamíferos e outros vertebrados (HOFGARTNER et al., 1979; SUMNER, 1990). Em Nysius californicus (Heteroptera, Lygaeidae), as marcações pela prata foram observadas em todas as fases da espermiogênese: nas espermátides arredondadas estavam localizadas na periferia do envoltório nuclear, na alongada e nos espermatozóides, na região posterior da cabeça (SOUZA et al., 2007b), assim como em Limnogonus aduncus (CASTANHOLE et al., 2008), Antiteuchus tripterus (SOUZA et al., 2008), Mormidae quinqueluteum, Oebalus poecilus e $O$. ypsilongreseus (SOUZA et al., 2008).

C. complanatus e L. deducta, analisadas no presente trabalho, também apresentaram marcações prata positiva, mostrando que a atividade sintética persiste ao longo da espermiogênese. Há, também, a possibilidade de que estas estruturas impregnadas pela prata sejam, por exemplo, alguma organela como a mitocôndria, ou o complexo de Golgi, ou corpo cromatóide (CB), estrutura esta descrita por Söderström e Parvinen (1976) e que possuem importante papel durante a espermiogênese tais como formação do acrossomo, transporte intercelular e formação da cauda do espermatozóide, pois segundo Monesi (1965) a transcrição de RNAm cessa nas espermátides iniciais, quando seus núcleos começam a alongar-se, entretanto o processo de síntese continua até os passos finais da espermiogênese, sendo realizado pelos CBs. Porém, para complementar o presente trabalho, estudos deverão ser realizados para a verificação da formação dessas estruturas e, também, a averiguação de sua função.

\section{Agradecimentos}

À Dra. Sônia Maria Oliani do Laboratório de Morfologia, IBILCE/UNESP por permitir utilizar o microscópio para capturar as imagens, ao Dr. Luis Antônio Alves Costa do Departamento de Entomologia do Museu 
Nacional do Rio de Janeiro, RJ pela identificação dos insetos, a CAPES, FAPESP e FUNDUNESP pelo apoio financeiro.

\section{Referências}

BRESSA, M.J.; PAPESCHI, A.G.; FUMAGALLI, E.; VAN DOESBURG, P.H.; LARRAMENDY, M.L. Cytogenetic and nucleolar meiotic cycle analyses in Dysdercus imitator Blõte, 1931 (Pyrrhocoridae, Heteroptera) from Argentina. Folia Biologica (Krakow), v. 51, p. 135-141, 2003.

CAMACHO, J.P.M.; BELDA, J.; CABRERO, J. Meiotic behaviour of the holocentric chromosomes of Nezera viridula (Insecta, Heteroptera) analyzed Cbanding and silver impregnation. Canc. J. Gent Cytol, v. 27, p. 490-497, 1985.

CASTANHOLE, M.M.U.; PEREIRA, L.L.V.; SOUZA, H.V.; BICUDO, H.E.M.C.; COSTA L.A.A.; ITOYAMA, M.M. Heteropicnotic chromatin and nucleolar activity in meiosis and spermiogenesis of Limnogonus aduncus (Heteroptera, Gerridae): a stained nucleolar organizing region that can serve as a model for studying chromosome behavior, Genetics and Molecular Research, v. 7, n. 4, p. 1398-1407, 2008.

CATTANI, M.V.; GREIZERSTEIN, E.J.; PAPESCHI, A.G. Male meiotic behaviour and nucleolus organizer regions in Camptischium clavipes (Fabr.) (Coreidae, Heteroptera) analyzed by florescent banding and in situ hybridization. Caryologia, v. 57, n. 3, p. 267-273, 2004.

FOSSEY, A.; LIEBENBERG, H. Meiosis and nucleolar structures in the stink bug Cartisis wahlbergi Stal (Coreidae: Heteroptera) Cytobios, v.81, p. 7-15, 1995.

GONZÁLEZ-GARCIA, J.M.; ANTONIO, C.; SUJA, J.A.; RUFAS, J.S. Meiosis in holocentric chromosomes: kinetic activity is randomly restricted to the chromatid ends of sex univalents in Graphosoma italicum (Heteroptera).

Chromosome Research, v. 4, p. 124-132, 1996. 
HOFGARTNER, F. J.; SCHMID, M.; KRONE, W.; ZENZES, M. T.; ENGEL, W. Pattern of activity of nucleolus organizers during spermatogenesis in mammals as analyzed by silverstaining. Chromosoma, v. 71, p. 197-216, 1979.

HOWELL W.M.; BLACK, D.A. Controlled silver-staining of nucleolus organizer regions with a protective colloidal developer: a 1-step method. Experientia, v. 36, p. 1014-1015, 1980.

MONESI, V. Synthetic activities during spermatogenesis in the mouse.

Experimental Cell Research, v. 39, n. 1, p. 197-224, 1965.

PAPESCHI, A.G; BRESSA, M.J. Cytogenetic studies in Belostomatidae from Argentina. Abstracts of the second quadrennial meeting of the International Heteropteristis Society, v. 46, 2002.

PAPESCHI, A.G.; MOLA, L.M.; BRESSA, M.J.; GREIZERSTEIN, E.J.; LÍA, V.; POGGIO, L. Behaviour of ring bivalents in holocentric systems: Alternative sites of spindle attachment in Pachylis argentinus and Nezara viridula (Heteroptera). Chromosome Research, v. 11, p. 725-733, 2003.

REBAGLIATI, P.J.; PAPESCHI, A.G.; MOLA, L.M. Meiosis and fluorescent banding in Edessa meditabunda and E. rufomarginata (Heteroptera:

Pentatomidae: Edessinae). European of Journal Entomology, v. 100, p. 11-18, 2003.

REBAGLIATI, P.J.; MOLA, L.M.; PAPESCHI, A.G.; GRAZIA, J. Cytogenetics studies in Pentatomidae (Heteroptera): A review. J.Zool Syst Evol Res, v. 43, p. 199-213, 2005

SCHAEFER C.W.; PANIZZI A. R. Heteroptera of economic importance. Ed. CRC Press, p. 421-474, 2000.

SCHRADER, F. Regular occurrence of heteroploidy in a group of Pentatomidae (Hemiptera). Biol. Bull., v. 88, p. 63-70, 1945a.

SCHRADER, F. The cytology of regular heteroploidy in the genus Loxa (Pentatomidae - Hemiptera). J. Morphol., v.76, p.157-177, 1945b. 
SCHRADER, F. The elimination of chromosomes in the metiotic divisions of Brachystethus rubromaculatus Dallas. Biol. Bull., v. 90, p. 19-31, 1946 a.

SCHRADER, F. Autossomal elimination and preferential segregation in the harlequin lobe of certain Discocephalini (Hemiptera). Biol. Bull., v. 90, p. 264$290,1946 b$.

SCHRADER, F. Cytological and evolutionary implications of aberrant chromosome behavior in the harlequin lobe of some Pentatomidae (Heteroptera). Chromosoma, v. 11, p. 103-128, 1960a.

SCHRADER, F. Evolutionary aspects of aberrant meiosis in some Pentatomidae (Heteroptera). Evolution, v. 14, p. 498-508, 1960 b.

SCHUH, T. T.; SLATER, J.A. The bugs of the world (Hemiptera: Heteroptera) Classification and natural history. Cornell UNIVERSITY press, 1995.

SÖDERSTRÖM K.O.; PARVINEN M. Transport of material between the nucleus, the chromatoid body and the golgi complex in the early spermatids of the rat. Cell and Tissue Research, v. 168, n. 3, p. 335-342, 1976.

SOUZA, H. V.; BICUDO, H. E. M. C.; COSTA L. A. A.; ITOYAMA, M. M. A study of meiosis and spermiogenesis in the testicular lobes of Antiteuchus tripterus (Heteroptera, Pentatomidae). European Journal of Entomology, v. 104 , p. 353-362, 2007a.

SOUZA, H. V.; BICUDO, H. E. M. C.; ITOYAMA, M. M. Study of chromosomal and nucleolar aspects in testes of Nysius californicus (Heteroptera, Lygaeidae). Genetics and Molecular Biology, v. 6, n. 1, p. 33-40, $2007 \mathrm{~b}$.

SOUZA, H. V.; CASTANHOLE, M. M. U.; BICUDO, H. E. M. C.; COSTA L. A. A.; ITOYAMA, M. M. Morphological patterns of the heteropycnotic chromatin and nucleolar material in meiosis and spermiogenesis of some Pentatomidae (Heteroptera). Genetics and Molecular Biology, v. 31, n. 3, p. 686691, 2008. 
SOUZA, H.V.; SOUZA, F.B.; ARUYAMA, S.R.C.; CASTANHOLE M.M.U.; ITOYAMA, M.M. Meiosis, spermatogenesis and nucleolar behavior in the seminiferous tubules of Alydidae, Coreidae and Rhopalidae (Heteroptera) species. Genetics and Molecular Research, v. 8, n. 4, p. 1383-1396, 2009.

SUMNER, A.T. Chromosome Banding. Unwin Hyman, London, 1990.

SWALLOW J.G.; WILKINSON G.S. The long and short of sperm polymorphisms in insects. Biological Reviews, v.77, p. 153-182, 2002.

TARTAROTTI E.; AZEREDO-OLIVEIRA M.T.V. Patterns of nucleolar activity during spermatogenesis of two triatomines, Panstrongylus megistus and $P$. herreri. Caryologia, v. 52, p. 177-184, 1999.

TAVARES, M. G.; AZEREDO-OLIVEIRA, M.J.V. Pattern of nucleolar activity during spermatogenesis in triatomines (Heteroptera: Reduvidae) as analysed by silver staining. Cytobios, v. 89, p. 93-103, 1997.

YOSHIDA, T. Unusual type of the nucleolus observed in a bug, Acanthocoris sordidus. Journal of the Faculty of Science- Hokkaido University. (Zool.), v. 9, p. 243-249, 1947. 

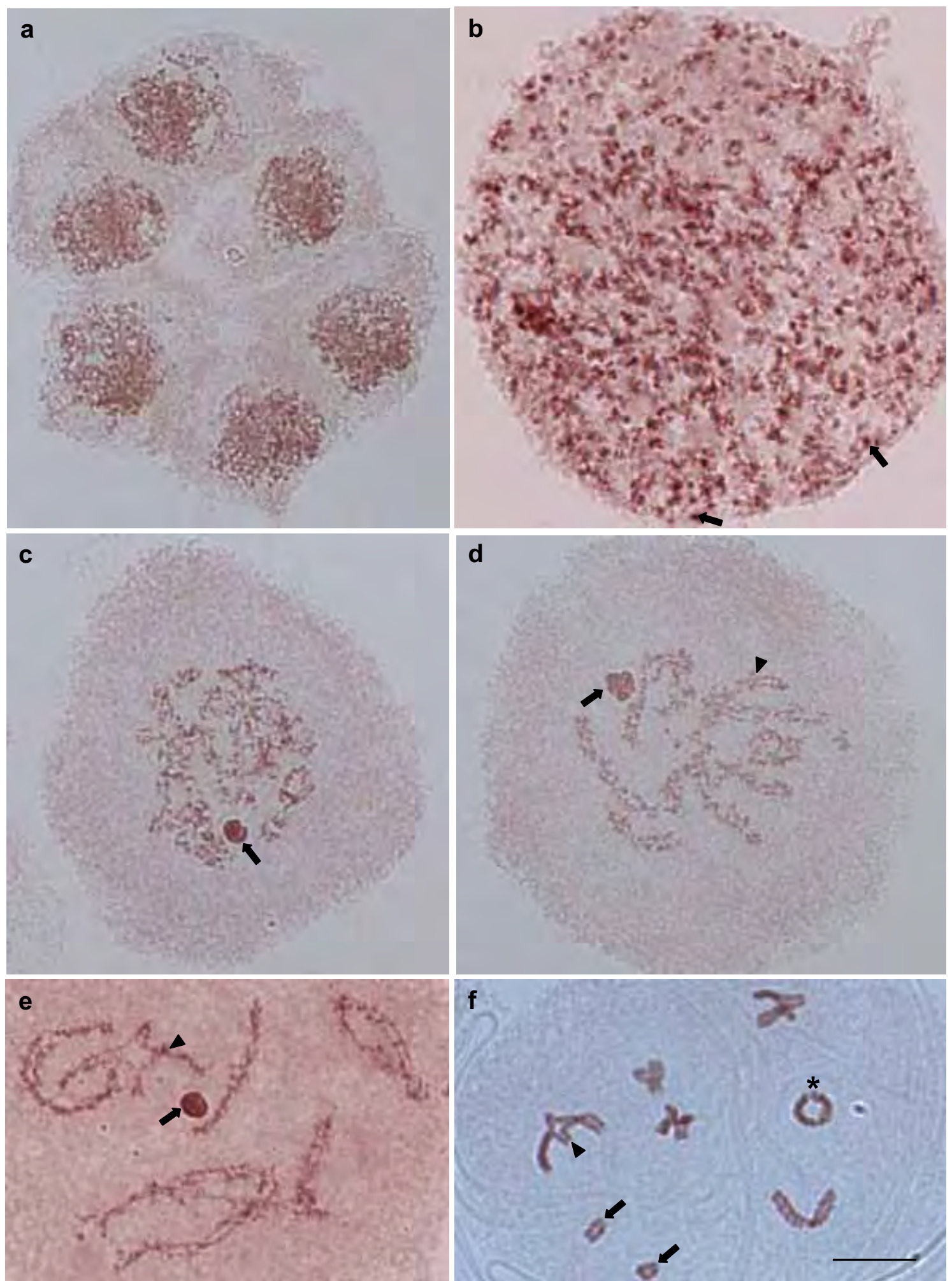

Figura 1. Células dos lobos testiculares 1, 2, 3, 4, 6 e 7 de Chlorocoris complanatus (b, e) e Loxa deducta (a, c, d, f) (Pentatomidae) coradas com orceína lacto-acética. a) cisto espermatogonial apresentando 6 espermatogônias; b) núcleo poliplóide com várias regiões heteropicnóticas pequenas (setas); c,d) zigóteno-paquíteno com apenas uma região heteropicnótica (seta) e quiasma (cabeça de seta); e) diplóteno mostrando um corpúsculo heteropicnótico e um quiasma intersticial (cabeça de seta); f) diacinese apresentando os cromossomos sexuais (setas) e os autossomos com quiasmas intersticial (cabeça de seta) ou terminal (asterisco). Barra: $10 \mu \mathrm{m}$. 

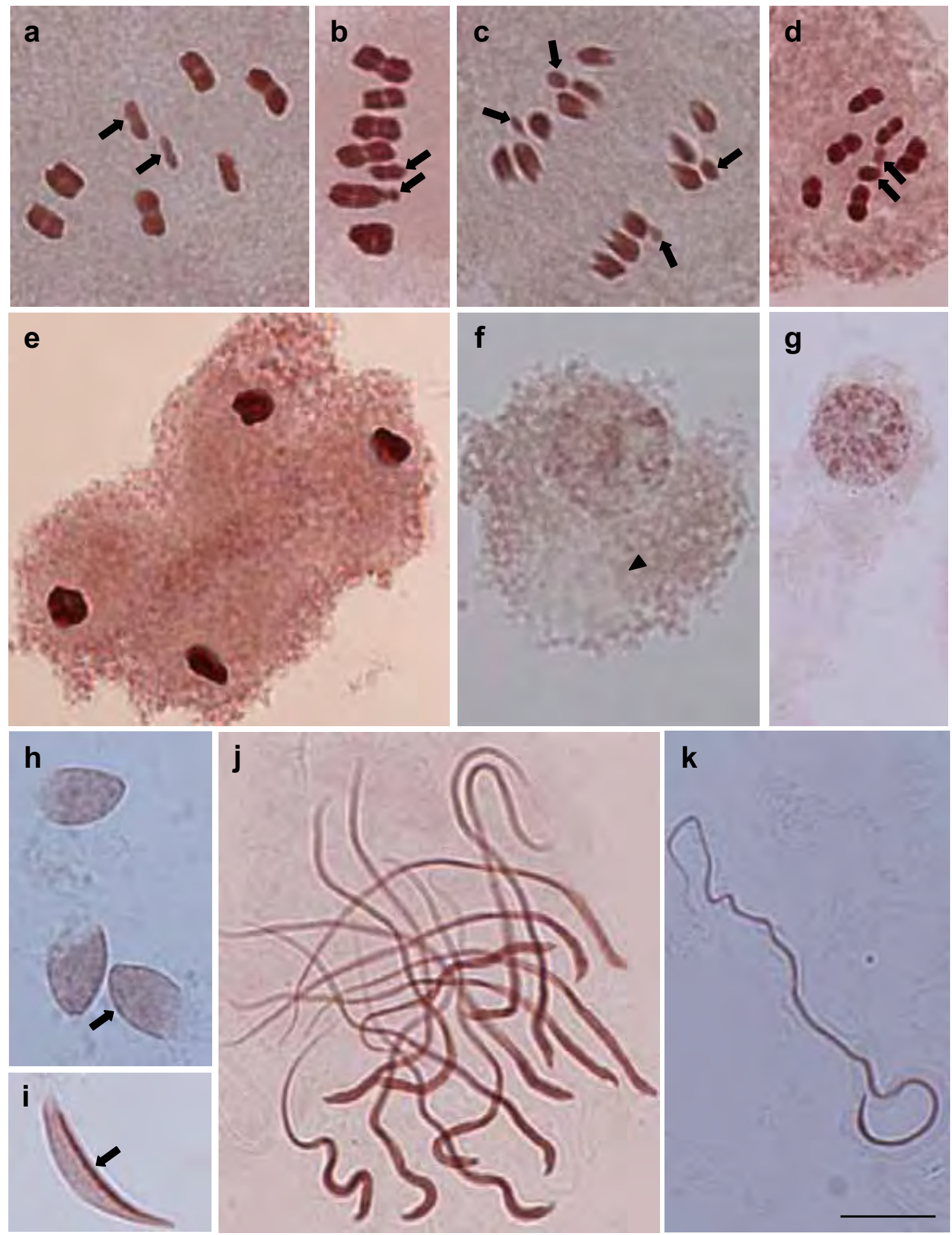

Figura 2. Células dos lobos testiculares 1, 2, 3, 4, 6 e 7 de Chlorocoris complanatus (b, d, g, i, j) e Loxa deducta (a, c, e, f, h, k) (Pentatomidae) coradas com orceína lacto-acética. a) metáfase I de $L$. deducta $\operatorname{com} 2 \mathrm{n}=14(12 \mathrm{~A}+\mathrm{XY})$ cromossomos; $\mathrm{b})$ metáfase I de $C$. complanatus com $2 \mathrm{n}=$ $14(12 \mathrm{~A}+\mathrm{XY})$ cromossomos. As setas mostram os cromossomos sexuais; c) final da anáfase I com as setas apontando os cromossomos sexuais; d) metáfase II. As setas indicam os cromossomos sexuais; e) telófase; f) espermátide inicial com cromatina dispersa e uma vesícula grande (cabeça de seta); g) espermátide com cromatina mais condensada; h) espermátides elípticas com material heteropicnótico ao redor do envoltório nuclear; i) espermátide em alongamento com a presença de material heteropicnótico em apenas um dos lados; j,k) espermátides em alongamento. Barra: $10 \mu \mathrm{m}$. 

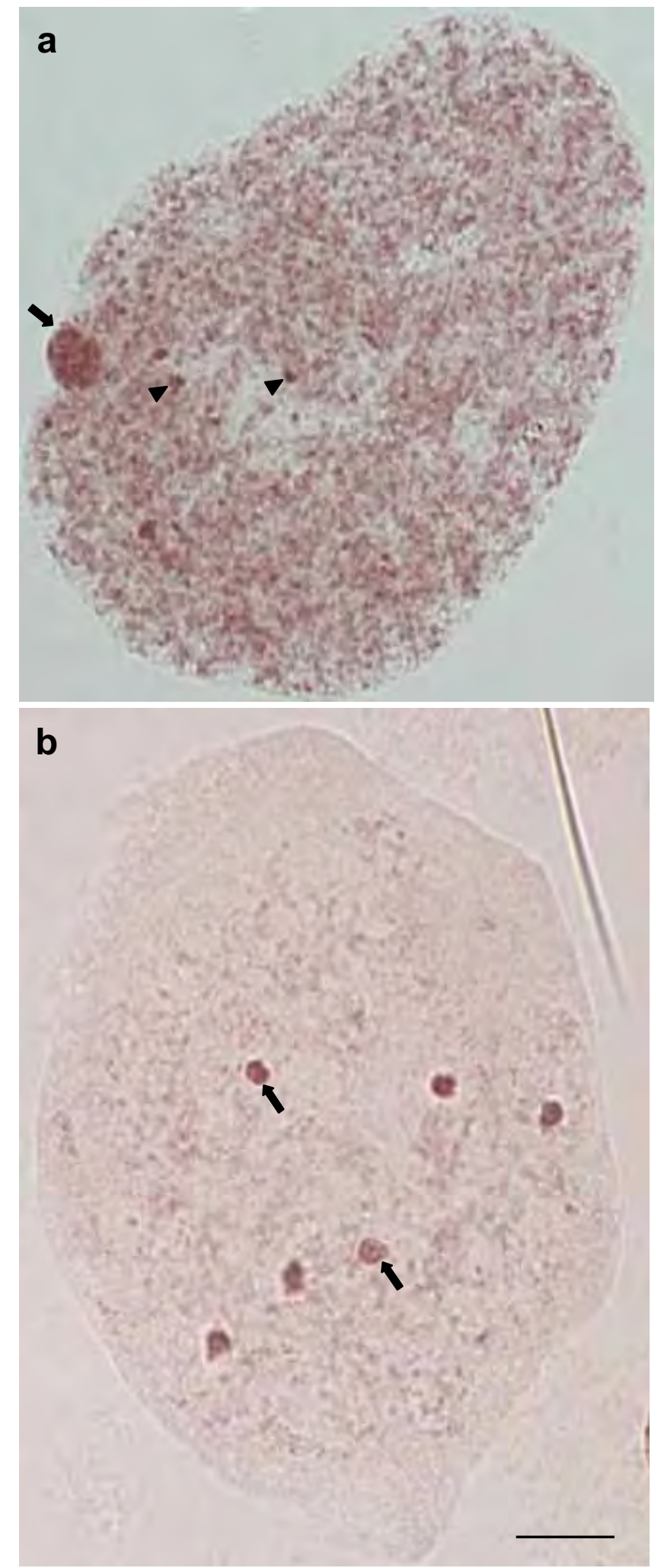

Figura 3. Células do lobo testicular 5 de Loxa deducta (Pentatomidae) coradas com orceína lacto-acética. a) núcleo poliplóide com uma região heteropicnótica grande (seta) e várias pequenas (cabeça de seta); b) célula em prófase contendo vários corpúsculos heteropicnóticos arredondados (setas). Barra: $10 \mu \mathrm{m}$. 

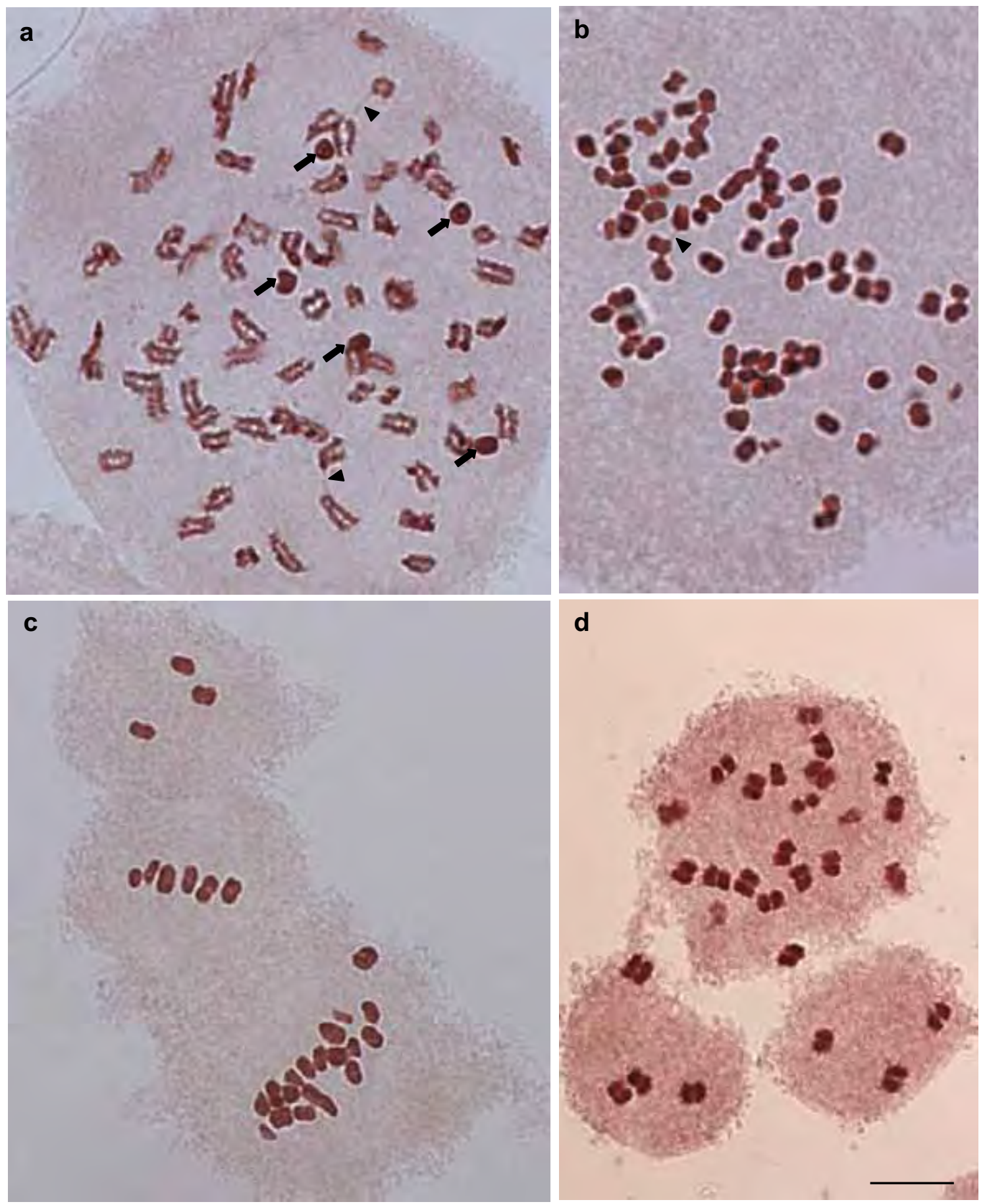

Figura 4. Células do lobo testicular 5 de Chlorocoris complanatus (a, b) e Loxa deducta (c, d) (Pentatomidae) coradas com orceína lacto-acética. a) célula em metáfase apresentando vários cromossomos condensados e várias regiões heteropicnóticas arredondadas (setas) e alguns cromossomos apresentando pontes cromatínicas (cabeça de seta); b) metáfase com vários cromossomos condensados apresentando, ainda, pontes cromatínicas (cabeça de seta); c,d) anáfases mostrando diferentes modos de divisão. Barra: $10 \mu \mathrm{m}$. 

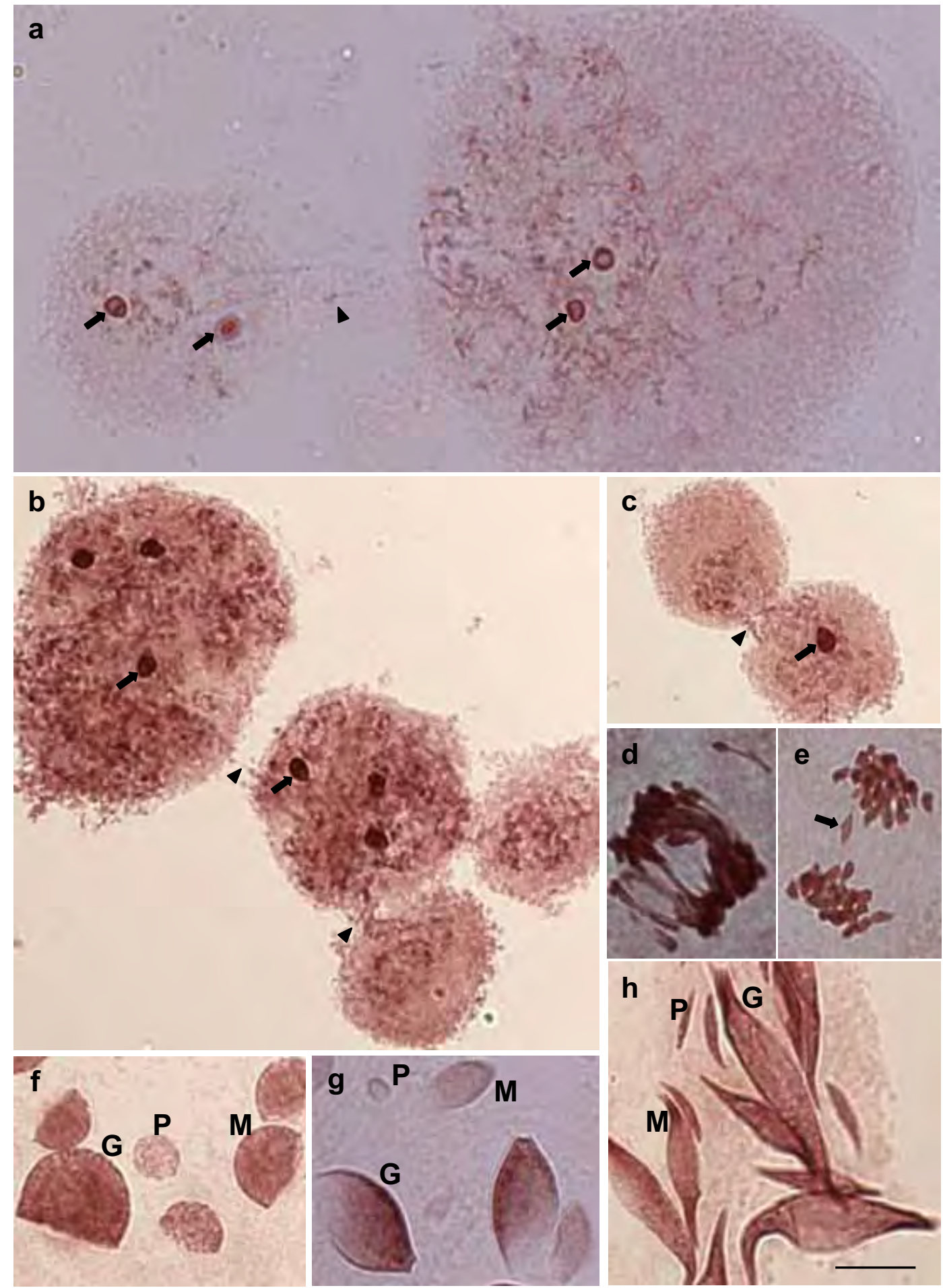

Figura 5. Células do lobo testicular 5 de Chlorocoris complanatus (a, g) e Loxa deducta (b, c, d, e, f, h) (Pentatomidae) coradas com orceína lacto-acética. a) anáfase apresentando distribuição desigual de material cromatínico. Observar as regiões heteropicnóticas (setas) e material cromatínico entre as duas células (cabeça de seta); b) anáfase mostrando vários corpúsculos heteropicnóticos (setas) e distribuição desigual de material genético para as células (cabeça de seta). Observar material cromatínico entre as células (cabeça de seta); c) anáfase mostrando separação do material genético e apenas um corpúsculo heteropicnótico (seta). Observar material genético no local de separação das células (cabeça de seta); d) anáfase inicial; e) anáfase final com migração tardia de cromossomo (seta); f) espermátides arredondadas com diferentes tamanhos: pequeno $(\mathrm{P})$, médio $(\mathrm{M})$ e grande $(\mathrm{G})$; g,h) espermátides em alongamento apresentando diferentes tamanhos: pequeno (P), médio (M) e grande (G). Barra: $10 \mu \mathrm{m}$. 

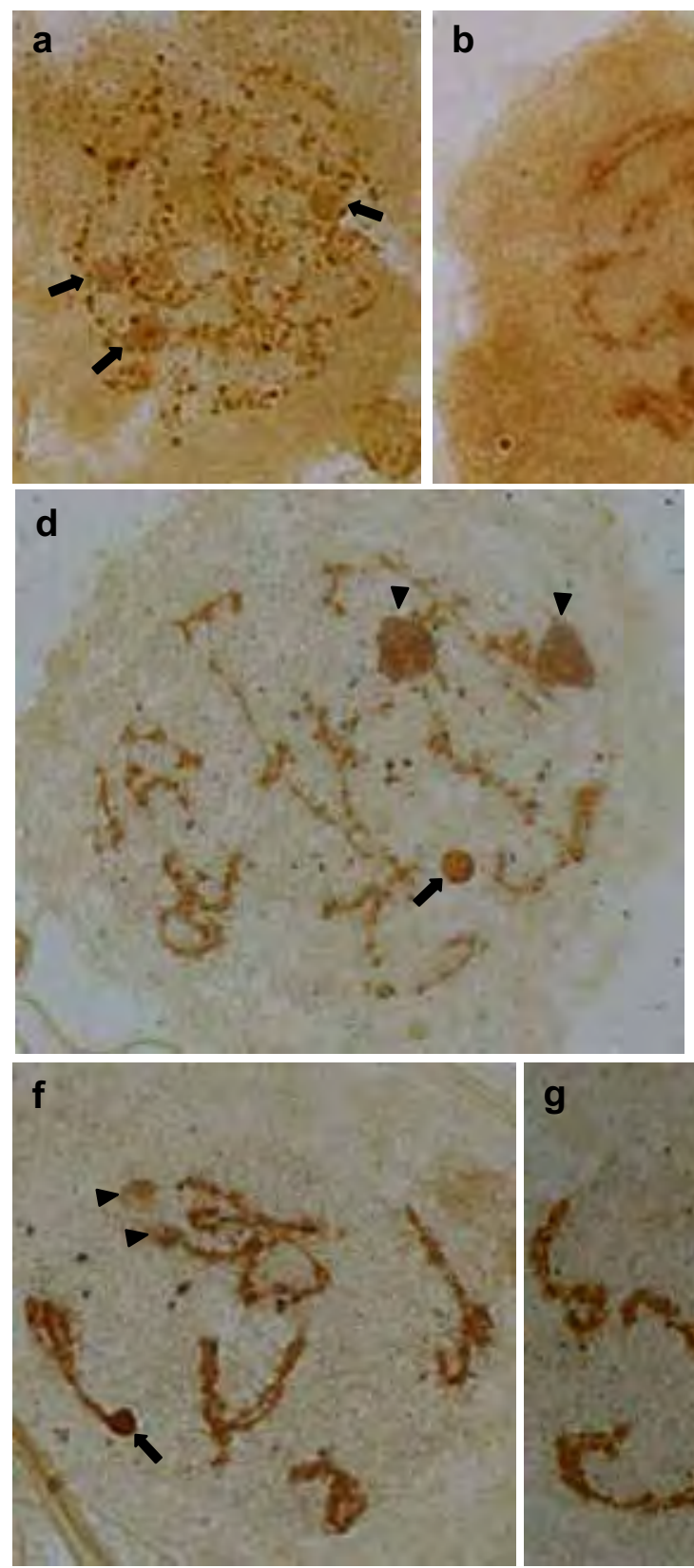
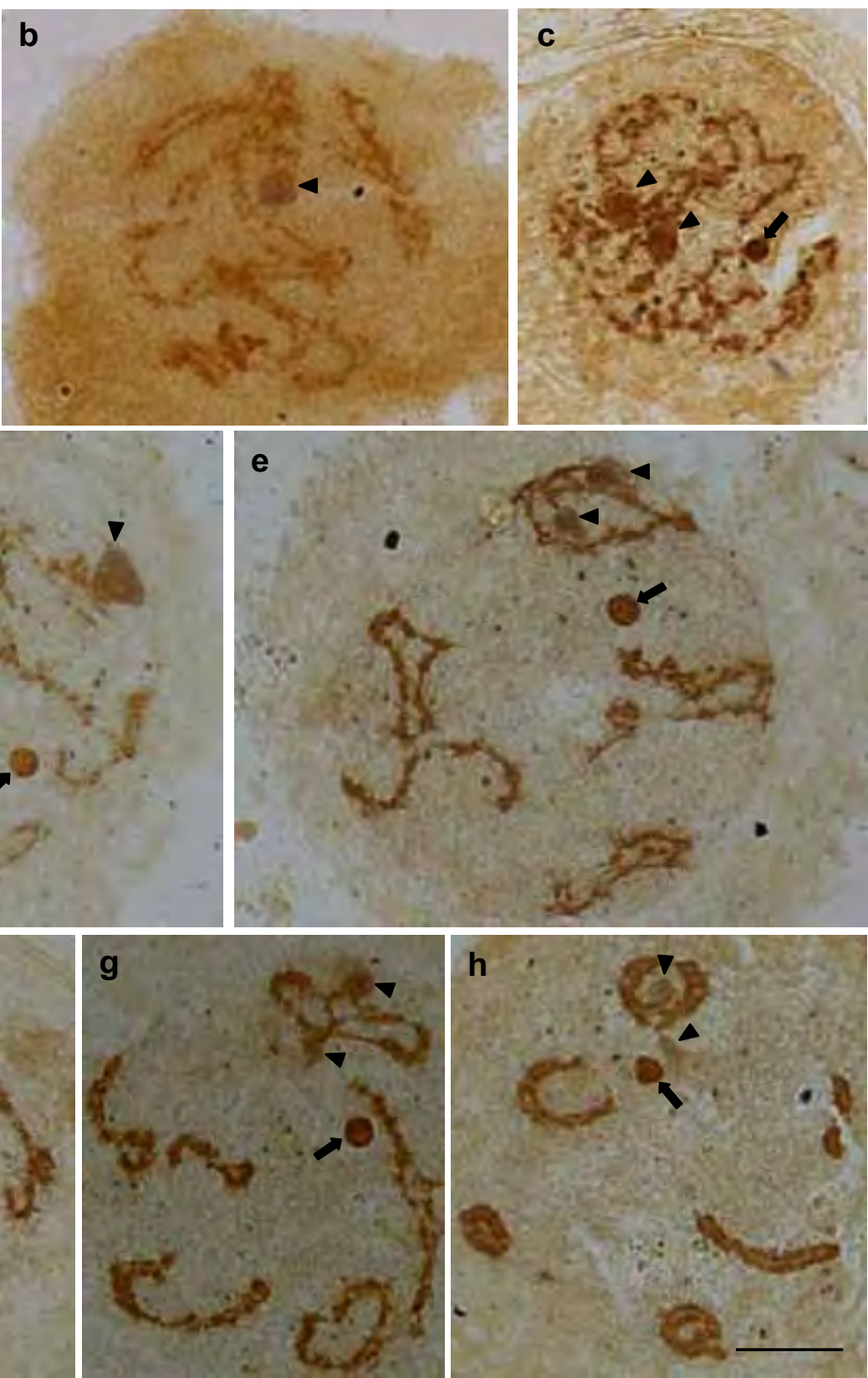

Figura 6. Células dos lobos testiculares 1, 2, 3, 4, 6 e 7 de Chlorocoris complanatus (a, c, f, g, h) e Loxa deducta (b, d, e) (Pentatomidae) impregnadas por íons prata. a) prófase inicial com algumas marcações (setas); b) prófase I inicial com um corpúsculo prata positivo (seta); c,d) diplóteno inicial com uma marcação arredondada pequena (seta) e duas maiores sem morfologia definida (cabeças de seta); e-h) verificar nessas células as associações dos cromossomos aos corpúsculos maiores (setas) e aos menores (cabeças de seta). Barra: $10 \mu \mathrm{m}$. 

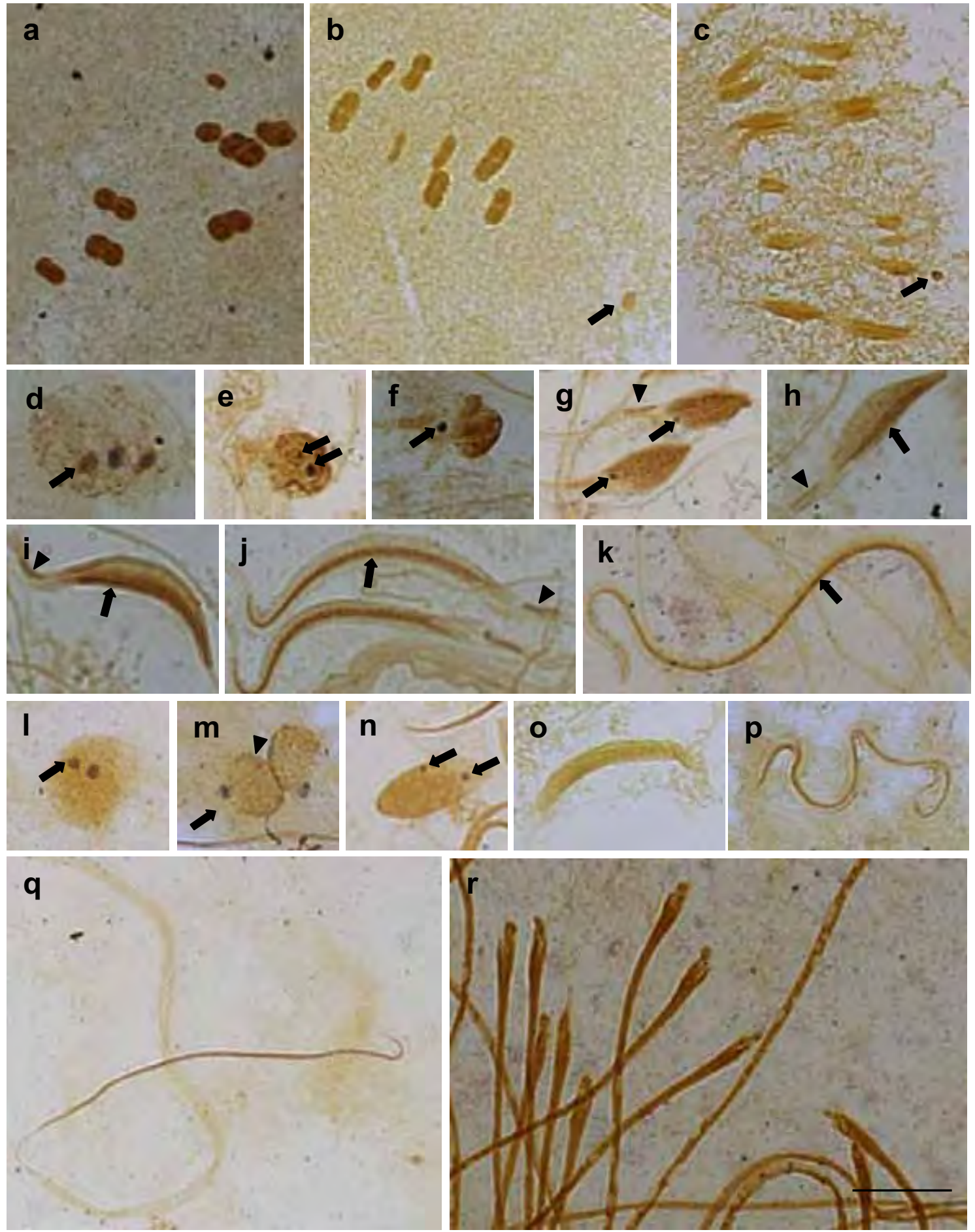

Figura 7. Células dos lobos testiculares 1, 2, 3, 4, 6 e 7 de Chlorocoris complanatus (a, d-k) e Loxa deducta (b, c, l-r) (Pentatomidae) impregnadas por íons prata. a) metáfase sem marcação; b,c) metáfase e anáfase de $L$. deducta com semi-persistência nucleolar (setas); d-k) espermiogênese de C. complanatus; d) espermátide arredondada com 3 corpúsculos prata positivo (seta); e) espermátide com 1 marcação menor e outra maior (setas); f) espermátide com uma marcação na região posterior (seta); g) espermátide elipsóide com uma marcação arredondada (seta) e outra alongada (cabeça de seta) na região posterior; h-k) observar que estas duas marcações permanecem ao longo do desenvolvimento da espermátide; 1-r) espermiogênese de L. deducta; 1) espermátide arredondada com dois corpúsculos prata positivo (seta); m) espermátide arredondada com um corpúsculo arredondado (seta) e marcação em um dos lados da membrana do núcleo (cabeça de seta); n) espermátide elipsóide com duas marcações prata positivo (setas); o-r) espermátides em alongamento, aparentemente sem material prata positivo. Barra: 10 $\mu \mathrm{m}$. 

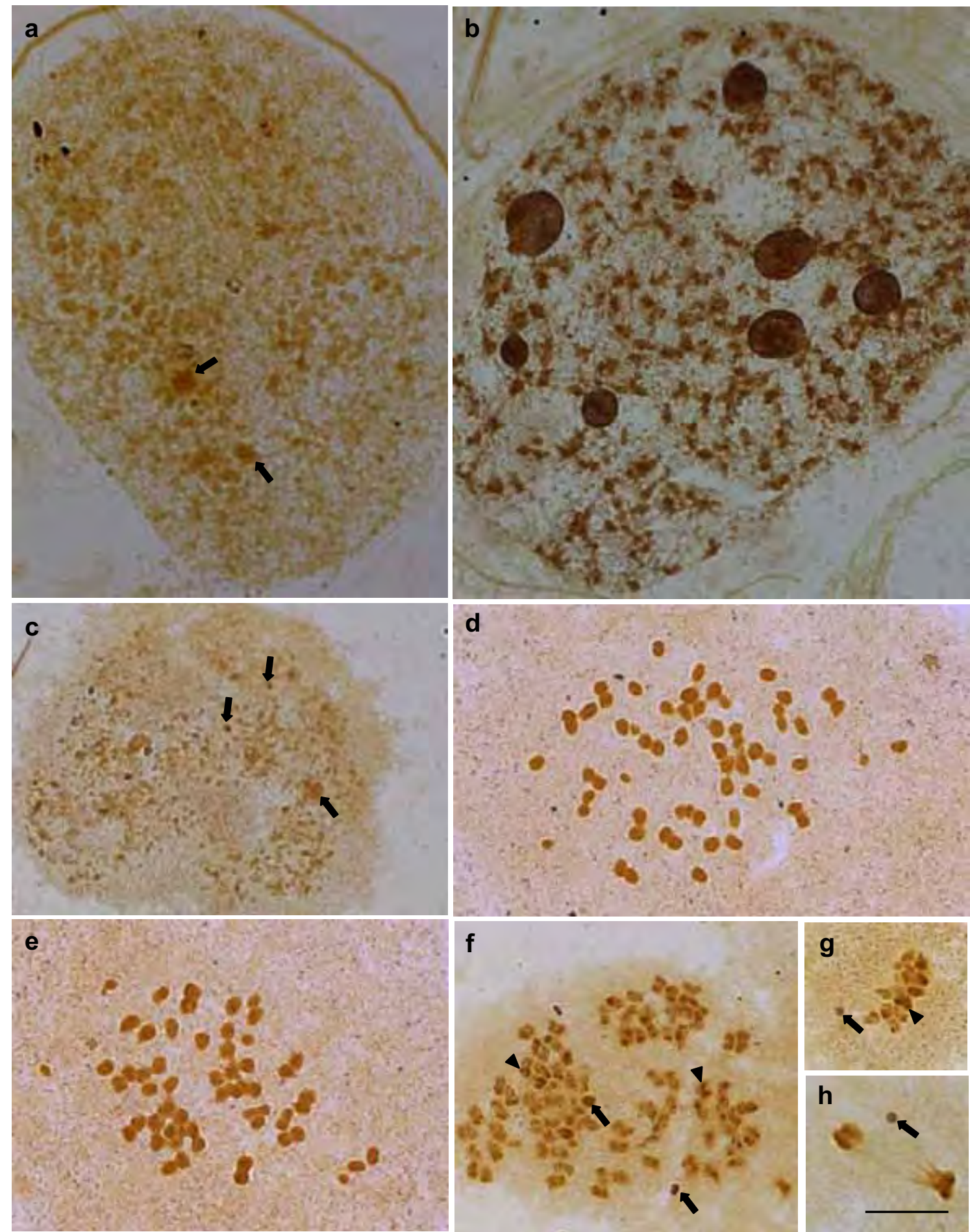

Figura 8. Células do lobo testicular 5 de Chlorocoris complanatus (b, d, e) e Loxa deducta (a, c, f, g, h) (Pentatomidae) impregnadas por íons prata. a-c) prófase com diversas marcações fracamente coradas (a, setas), vários corpúsculos arredondados e fortemente impregnados (b) ou com algumas marcações pouco coradas e algumas maiores e mais impregnadas (c, setas); d,e) metáfases sem marcações; f-g) metáfases com marcações na bainha pericromossômica (cabeças de seta) e corpúsculos prata positivo (setas); h) anáfase com um corpúsculo prata positivo. Barra: $10 \mu \mathrm{m}$. 

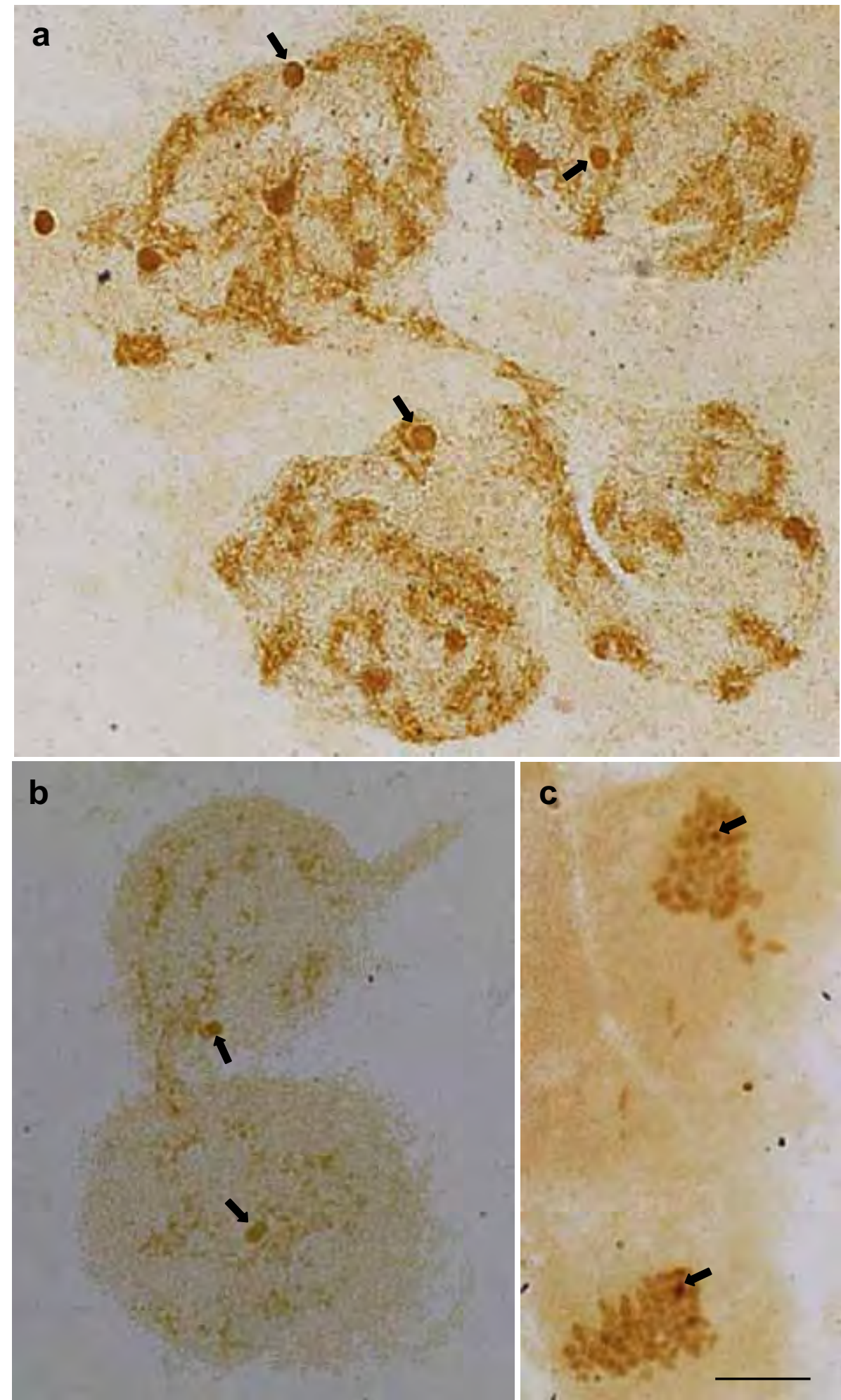

Figura 9. Células do lobo testicular 5 de Chlorocoris complanatus (a) e Loxa deducta (b, c) (Pentatomidae) impregnadas por íons prata. a-c) anáfases com cromossomos descondensados apresentando números variáveis de corpúsculos prata positivo (setas). Barra: $10 \mu \mathrm{m}$. 

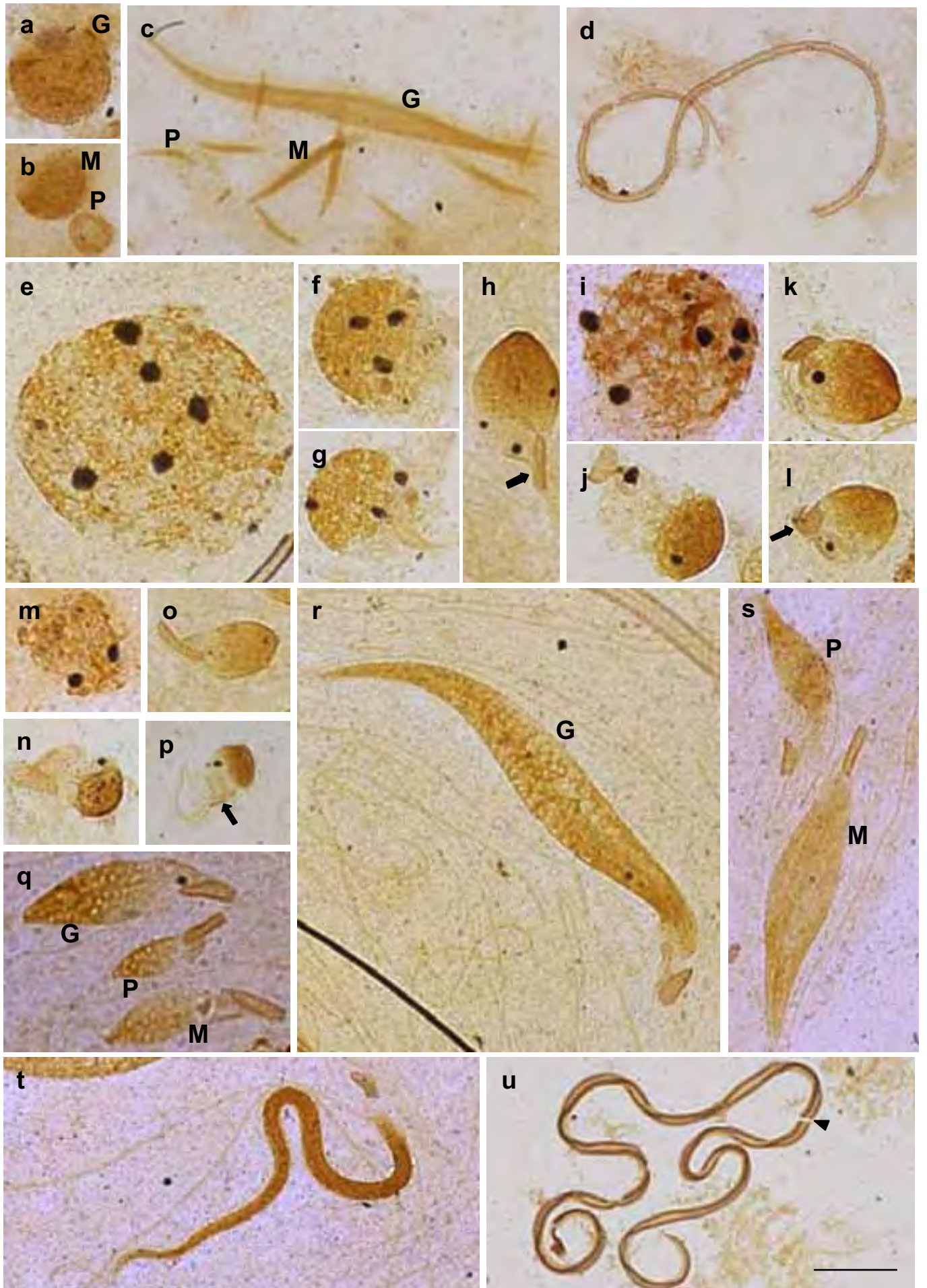

Figura 10. Células do lobo testicular 5 de Chlorocoris complanatus (e, f, g, h, i, j, k, l, m, n, o, p, q, r, s) e Loxa deducta (a, b, c, d) (Pentatomidae) impregnadas por íons prata. a,b) espermátides arredondadas de $L$. deducta com diferentes tamanhos: pequeno $(\mathrm{P})$, médio $(\mathrm{M})$ e grande $(\mathrm{G})$; c) espermátides P, M e G em alongamento; d) espermatozóide em formação; e-u) espermiogênese de C. complanatus; e-h) espermátides grandes apresentando inicialmente 5 corpúsculos prata positivo (e), posteriormente 3 (f,g) e numa fase mais adiantada do alongamento os corpúsculos estão mais na região posterior e há a formação de uma estrutura alongada (seta); i-1) início da espermiogênese da espermátide média, apresentando inicialmente 5 corpúsculos (i), posteriormente permanece um único com surgimento da estrutura alongada na parte posterior da cabeça (j-1, seta); m-p) espermiogênese da espermátide pequena; m) espermátide com 2 corpúsculos; n-p) espermátides com um corpúsculo arredondado e outro alongado (seta); q-t) alongamento das espermátides $\mathrm{P}, \mathrm{M} \mathrm{e} \mathrm{G}$; u) espermátide em alongamento com regiões de fragmentação (cabeça de seta). Barra: $10 \mu \mathrm{m}$. 


\section{Comportamento da espermatogênese nos lobos testiculares de três espécies da família Pentomidae (Heteroptera)}

MURAKAMI, Aline Sumitani; SOUZA, Hederson Vinícius de; MARQUES, Inaiá Fernandes Gallego; ITOYAMA, Mary Massumi

UNESP-Universidade Estadual Paulista, Instituto de Biociências, Letras e Ciências Exatas, Departamento de Biologia, Laboratório de Citogenética e Molecular de Insetos-LACIMI

\section{Resumo}

No presente trabalho, analisamos a espermatogênese das espécies Edessa affins, Edessa meditabunda e Thyanta perditor (Pentatomidae). Os testículos desses insetos são formados de 4, 4 e 3 lobos, respectivamente. Apesar de não apresentarem o lobo harlequin, observou-se que a espermiogênese do lobo 4 (que é maior que os demais lobos) de E. affins e E. meditabunda, após impregnação por íons prata, são diferentes dos demais lobos, sendo indicativos, talvez, de um processo intermediário para formação de espermatozóides não-fecundantes. As diferenças nas espermátides relacionam-se, principalmente, com relação à morfologia. A parte posterior da cabeça apresenta uma expansão com vários corpúsculos prata positivo que parece se dividir formando duas "caudas" que, posteriormente, se separam da parte inicial da cabeça. Em E. meditabunda há 3 regiões na cabeça da espermátide que apresentam aumento do diâmetro, sendo as 2 primeiras mais impregnadas e a terceira possui diâmetro maior, mas é menos impregnada. Numa fase posterior, visualizam-se regiões de quebra na região mais impregnada. Com relação ao comportamento meiótico, as 3 espécies foram semelhantes. As células em prófase I apresentam material heteropicnótico, os cromossomos associam-se telomericamente e são quiasmáticos. $E$ affins apresentou $2 \mathrm{n}=16(14 \mathrm{~A}+\mathrm{XY})$ e E. meditabunda e T. perditor $2 \mathrm{n}=14(12 \mathrm{~A}+$ $\mathrm{XY})$. 
Palavras-chave: espermatogênese, meiose, cromossomos holocêntricos, comportamento nucleolar

\section{Introdução}

Os Pentatomidae ou "maria-fedidas" possuem cromossomos holocêntricos, os quais são caracterizados por possuírem centrômero por todo o comprimento do cromossomo (PEREZ et al., 2000; SOUZA et al., 2007a). Estes insetos possuem comportamento peculiar durante a meiose: a primeira divisão é reducional para os autossomos e equacional para os cromossomos sexuais (GONZALEZ-GARCIA, 1996; SOUZA et al., 2007b; COSTA et al., 2008).

Os Pentatomidae apresentam número diplóide de $2 n=14$ cromossomos, sistema cromossômico do sexo $\mathrm{XY} / \mathrm{XX}$ e não possuem mcromossomos. Entretanto, uma característica particular de algumas espécies é a presença de uma meiose anormal em um lobo testicular particular, denominado de lobo harlequin (SCHRADER 1945a, b, 1946a, b, 1960a, b).

Vários autores têm estudado as regiões organizadoras nucleolares (RON) em Heteroptera (CAMACHO et al., 1985; FOSSEY; LIEBENBERG, 1995; CATTANI; PAPESCHI, 2004; CASTANHOLE et al., 2008). Nos Pentatomidae, uma única RON foi detectada na posição mediana em um par de autossomos grande em Nezara viridula (CAMACHO et al., 1985; PAPESCHI et al., 2003) ou na região telomérica do cromossomo $\mathrm{X}$ de Graphosoma italicum (GONZALEZ-GARCIA et al., 1996).

Em algumas famílias como, por exemplo, a Reduviidae (Triatominae e Harpactorinae) e a Pentatomidae, há semi-persistência nucleolar (TARTAROTTI; AZEREDO-OLIVEIRA, 1999; MORIELLE; AZEREDOOLIVEIRA, 2004). Em outras famílias o material prata positivo é observado na bainha pericromossômica durante as metáfases (SOUZA et al., 2008). Alguns trabalhos com insetos discutem o que realmente a impregnação por íons prata marca. Suja et al. (1991) sugere que o material prata positivo é material cinetocórico ou centromérico. Análises ultra-estruturais da espermatogênese de 
Tricholepidium (Insecta) observou material granular difuso, relacionado ao centríolo nas espermátides iniciais (DALLAI et al., 2001).

Diante das variedades de características dos Pentatomidae, tais como a presença ou não de lobo harlequin, variedade de complementos cromossômicos e comportamentos nucleolares, o objetivo do nosso trabalho foi o de ampliar as informações citogenéticas desta família, já que ela é uma das maiores da ordem e apresenta algumas espécies de importância econômica, pois são pragas de lavouras.

\section{Materiais e Métodos}

Neste presente trabalho foram utilizados 15 machos adultos de cada espécie de Edessa affins (Pentatomidae, Edessinae), Edessa meditabunda (Pentatomidae, Edessinae) e Thyanta perditor (Pentatomidae, Pentatominae) que foram coletados no município de São José do Rio Preto-SP (2047'32"S, 49 $21^{\prime} 37^{\prime \prime} \mathrm{W}$ ) em pés de pitanga (Eugenia uniflora), boldo (Plectranthus barbatus) e capim (Andropogon citratus), respectivamente. Após a coleta foram eterizados e dissecados, já que a espermatogênese em Heteroptera não se encerra no estágio de ninfa. Os testículos extraídos tiveram os lobos individualizados, colocados em lâminas, separadamente, dilacerados e corados com orceína lacto-acética ou impregnados por íons prata segundo protocolo modificado de Howell e Black (1980), para o estudo citogenético da meiose e espermiogênese. As amostras que não foram utilizadas logo após a coleta foram fixadas em metanol:ácido-acético (3:1) e mantidas a $8^{\circ} \mathrm{C}$. As lâminas foram analisadas no microscópio de luz Olympus modelo BX40 do Laboratório de Citogenética e Molecular de Insetos (LACIMI) e as melhores imagens foram capturadas no microscópio de luz AXIOSKOP 2 ZEISS (programa AXIOVISION) do laboratório de Morfologia, do Departamento de Biologia do IBILCE/UNESP, São José do Rio Preto - SP. 


\section{Resultados}

Observação das células após coloração com orceína lacto-acética

A análise dos testículos de Edessa affins, Edessa meditabunda e Thyanta perditor (Pentatomidae) permitiu-nos verificar que elas possuem 4 (E. affins e E. meditabunda) ou 3 lobos (T. perditor) alongados. Com relação à membrana que os reveste observou-se que E. affins possui membrana amarelada envolvendo todo o conjunto de lobos e unindo-os apresentam membrana vermelha escura na região proximal e transparente na distal; E. meditabunda possui membrana alaranjada envolvendo todo o conjunto de lobos e vermelha escura unindo os lobos e em $T$. perditor a membrana é amarelada na região proximal e transparente na distal.

Uma característica, já descrita na literatura, é a de que algumas espécies de Heteroptera possuem um lobo diferente denominado de harlequin. Por este motivo os lobos foram analisados separadamente, mas observou-se que estas espécies não os possui, portanto os resultados dos diferentes lobos estão sendo apresentados em conjunto, assim como o comportamento das células durante a espermatogênese das três espécies, que também foram semelhantes.

Os núcleos poliplóides das células nutritivas apresentaram algumas regiões heteropicnóticas pequenas distribuídas aleatoriamente pela célula (Figura 1a). Durante a espermatogênese, pode-se observar que as células meióticas em leptóteno-zigóteno apresentam um ou dois corpúsculos heteropicnóticos arredondados que possivelmente são os cromossomos sexuais (Figura 1c). Esses corpúsculos podem estar separados formando duas regiões heteropicnóticas de tamanhos diferentes (Figura 1c,d). Além destas regiões, observamos que em $E$. affins há outras regiões heteropicnóticas bem menores nas regiões terminais (Figura 1b). Durante a condensação cromossômica, observa-se a presença de quiasmas intersticiais (Figura 1e) e cromossomos com associações teloméricas em T. perditor (Figura 1f). Nas metáfases I, observamos que o complemento cromossômico de E. affins é de 2n=16 (14A + XY) (Figura 1h), de 
E. meditabunda é de $2 \mathrm{n}=14(12 \mathrm{~A}+\mathrm{XY})$ (Figura 1g, visão polar e Figura 1i , visão lateral) e de $T$. perditor de $2 \mathrm{n}=14(12 \mathrm{~A}+\mathrm{XY})$ cromossomos (Figura $1 \mathrm{j})$. Na Figura $1 \mathrm{k}$, observamos uma anáfase em fase inicial e, geralmente nessa fase, ocorre migração tardia do cromossomo sexual (Figura 11). Na telófase, observa-se os autossomos formando um anel e os cromossomos sexuais no seu centro (Figura $1 \mathrm{~m}, \mathrm{n})$.

A espermiogênese de E. meditabunda inicia-se com espermátides arredondadas com material cromatínico deslocado para um dos lados da célula e, ao lado, uma vesícula grande (Figura 10). O material cromatínico parece envolver esta vesícula (Figura 1o,p), sendo esta característica somente observada nesta espécie. Em um estágio mais avançado da espermiogênese, observa-se material heteropicnótico ao redor do envoltório nuclear e uma vesícula grande (Figura 1q), que não é mais observada em um estágio posterior (Figura 1r) e o material heteropicnótico distribui-se ao redor de somente 3/4 do envoltório nuclear. Neste estágio, observa-se, ainda, em $E$. meditabunda e em $T$. perditor uma região heteropicnótica no centro, sendo em $T$. perditor mais fortemente corada (Figura 1s,t). Com o alongamento da espermátide, o material heteropicnótico é observado por todo o seu comprimento nas laterais da membrana. Somente em T. perditor, o material heteropicnótico persiste nas espermátides alongadas (Figura 1u). Nas espermátides mais alongadas a região heteropicnótica persiste em apenas um dos lados em E. affins e E. meditabunda (Figura 1v). Em T. perditor, a região heteropicnótica é observada por toda a extensão, mas, também, localiza-se na região central da cabeça interligando a região anterior com a posterior (Figura $1 \mathrm{w}, \mathrm{x}$ ). No final do processo a cauda torna-se longa e a cabeça pequena (Figura 1z).

Observação das células após impregnação por íons de prata

As análises dos lobos testiculares de Edessa affins, Edessa meditabunda e Thyanta perditor mostraram que o comportamento nucleolar durante a meiose foi semelhante entre os lobos e as espécies, portanto os 
resultados foram agrupados. Os núcleos poliplóides das células nutritivas apresentaram em torno de quatro corpúsculos nucleolares de diferentes tamanhos, sem morfologia definida (Figura 2a-c). Durante a prófase I (Figura 2d-j), observase a presença de um ou mais corpúsculos prata positivo em $T$. perditor (Figura 2e,g) e uma ou duas marcações mais evidentes e várias menos evidentes em $E$. affins e E. meditabunda (Figura 2d,f,h). Até o final da prófase, o material prata positivo desorganizou-se (Figura 2i). Nas metáfases, não foi possível observar as regiões organizadoras nucleolares (RONs) (Figura 21,m), com exceção de $T$. perditor em que houve uma tênue marcação na região telomérica de um dos autossomos (Figura 2j,k). Nestes organismos não há material nucleolar durante a metáfase e anáfase (Figura 21-n). Durante a telófase, observa-se muitos pontos prata positivo no citoplasma das 2 células em formação (Figura 2o). Numa fase mais adiantada observa-se em torno de 4 a 6 corpúsculos prata positivo nas duas células em formação (Figura 2p).

Após análise de cada lobo, verificou-se que durante a espermiogênese todos os lobos de E. affins, E. meditabunda e T. perditor, apresentaram resultados semelhantes, com exceção do lobo 4 de E. affins e E. meditabunda, por esse motivo os resultados deste lobo serão apresentados separadamente.

A espermiogênese dos lobos 1,2 e 3 de E. affins, E. meditabunda e todos de $T$. perditor apresentaram espermátides iniciais com um ou dois corpúsculos prata positivo no início do desenvolvimento (Figura 3a) e numa fase mais adiantada apresentaram de 2 a 6 (Figura 3b-d). No início do desenvolvimento há um corpúsculo arredondado prata positivo na região central e marcação em apenas um dos lados da membrana (Figura 3e), posteriormente observa-se que a marcação arredondada migra para a região posterior da espermátide tornando-se alongada e há aumento da impregnação em um dos lados da espermátide (Figura 3f). A espermátide que atinge a forma elíptica possui marcação somente na região posterior da cabeça (Figura $3 \mathrm{~g}$ ). A marcação da região posterior torna-se mais forte e em forma de 2 discos apostos sendo que a cauda está ligada a apenas um deles (Figura 3h). Com o desenvolvimento, as 
marcações vão ficando menos evidentes, observando-se na região posterior e ao longo de todo comprimento, em apenas um dos lados (Figura 3h,i). Numa fase de alongamento mais adiantada as 3 espécies apresentam comportamentos diferentes: T. perditor apresentou uma pequena marcação na região posterior e anterior (Figura 3k), E. meditabunda ao longo de toda espermátide (Figura 31) e E. affins a marcação foi bem evidente em toda região anterior da cabeça (Figura $3 \mathrm{~m}$ ). No final do desenvolvimento, não se observa mais nenhuma marcação (Figura 3n).

Como mencionado anteriormente, a espermiogênese do lobo 4

de E. affins e E. meditabunda foram diferentes, principalmente durante o alongamento. As espermátides de E. affins apresentaram um aumento na região posterior da cabeça que apresenta alguns corpúsculos prata positivo (Figura 4a). A seguir, parece que há formação de duas “caudas" (Figura 4b). Num momento subseqüente, parece que esta estrutura separa-se da cabeça (Figura 4c) e, posteriormente, as 2 estruturas acabam se separando (Figura 4e,f). Foi visualizado em algumas espermátides, regiões de fragmentação (Figura 4d). Observou-se, ainda, espermátides bastante alongadas (Figura 4g). Em E. meditabunda as espermátides apresentaram 3 regiões que apresentam aumento no diâmetro da cabeça sendo as duas primeiras bem mais impregnadas e a terceira o diâmetro é maior, mas a impregnação é menor. Entre estas 3 regiões, há regiões da cabeça que apresentam, aparentemente, diâmetro normal (Figura 5a,b). Numa fase subsequente, as regiões mais impregnadas se fragmentam (Figura 5c,d). A região menos corada aumenta de tamanho e a parede começa a se desorganizar (Figura 5c, e). Há espermátides que aparecem com várias regiões de fragmentação.

\section{Discussão}

Os testículos dos Heteroptera são constituídos caracteristicamente por lobos dispostos lado a lado e envoltos por uma membrana. As espécies analisadas apresentaram 4 (Edessa affins e E. meditabunda) e 3 (Thyanta perditor) lobos e a membrana que reveste o testículo era, para E. affins, amarelada, envolvendo o conjunto de lobos e unindo os lobos membrana 
vermelha escura na região proximal e transparente na distal; para E. meditabunda a membrana que envolve o conjunto de lobos é alaranjada e a que envolve os lobos é vermelha escura; T. perditor apresentou membrana amarelada na região proximal e transparente na distal. Segundo a literatura o número de lobos na família Lygaeidae varia, tendo sido encontrados indivíduos com dois, quatro, seis e sete lobos, sendo sete considerado o número ancestral (GROZEVA; KUZNETSOVA, 1992). As subfamílias Arthencinae, Oxycareninae e alguns Lygaeinae como Paranysius fraterculus possuem o menor número de lobos, somente dois (GROZEVA e KUZNETSOVA, 1992). Nysius californicus (Lygaeidae) apresenta 7 lobos envoltos por uma membrana avermelhada. Este número de lobos a coloca entre as espécies portadoras das características ancestrais, segundo Souza et al. (2007b). Mormidae v-luteum, Oebalus poecilus e O. ypisilongrisus (Pentatomidae, Pentatominae) possuem 3, 4 e 4 lobos, respectivamente (SOUZA et al., 2008). Antiteuchus tripterus (Pentatomidae, Pentatominae) possui 6 lobos sendo o sexto interno ao quinto (SOUZA et al., 2007a). As espécies analisadas no presente trabalho possuem 4 (E. affins e E. meditabunda, Edesseinae) ou 3 lobos (T. perditor, Pentatominae). A partir das informações adquiridas, até o momento, não se pode concluir o número característico de lobos de cada família e qual é o número de lobos ancestral.

Uma outra característica de algumas espécies da família Pentatomidae é a presença de um lobo com características diferentes dos demais, denominado de lobo harlequin. As subfamílias que, geralmente apresentam este lobo são a Edessinae, a Pentatominae e a Discocephalinae. Segundo Rebagliati et al. (2005) a presença destes lobos poderia estar relacionada com o meio ambiente no qual esses insetos vivem. Entretanto, estudos com Antiteuchus tripterus (Pentatomidae), não parece corroborar essa idéia, porque exemplares coletados em diferentes Estados do Brasil, com ambientes bastantes diferentes (São Paulo, SOUZA et al., 2007a; Pernambuco, Alagoas e Bahia, LANZONE; SOUZA, 2006) revelaram a presença do lobo em ambos os locais, sugerindo, assim, que se trata de uma característica do gênero Antiteuchus, antes que ser um efeito ambiental. 
As espécies analisadas no presente trabalho não apresentaram o lobo harlequin apesar da subfamília a que pertencem, Edessinae e Pentatominae, se caracterizarem por apresentar esse lobo diferenciado. Contudo a espermiogênese de E. meditabunda e $E$. affins do lobo 4 foi diferente dos demais. Talvez este possa ser um processo intermediário para a formação de espermatozóides não-fecundantes.

Nas espécies em estudo, verificou-se a presença de material nucleolar durante quase todo o processo da espermatogênese, sugerindo a ocorrência de síntese protéica durante todo processo. No decorrer do processo, porém, ocorreram variações de tamanho, forma e localização, o que indica o envolvimento funcional dinâmico do material nucleolar, nas diferentes etapas do processo. Sabe-se da literatura que a quantidade de material nucleolar está relacionada com a atividade biossintética da célula. Assim, o tamanho e o número de nucléolos ou corpúsculos nucleolares podem refletir diferenças metabólicas entre as diferentes etapas.

No presente trabalho, somente $T$. perditor apresentou a região da RON em um autossomo. Em espécies de Panstrogylus (Heteroptera, Reduviidae), marcações de prata foram visualisadas somente até a espermátide inicial (arredondada), desaparecendo durante a sua elongação (TARTAROTTI; AZEREDO-OLIVEIRA, 1999), corroborando a hipótese de reativação pósmeiótica dos genes para RNAr. Esse processo foi observado também em mamíferos e outros vertebrados (HOFGARTNER et al., 1979; SUMNER, 1990).

A presença de material prata positivo talvez não seja indicativo de material nucleolar e sim cinecótoro ou material centromérico (SUJA et al., 1991; RUFAS; GOSÁLVEZ, 1982), necessitando, portanto, de mais estudos para a sua confirmação.

O número e a localização das RONs são conhecidos em poucas espécies de Heteroptera, tendo sido determinados por diferentes técnicas citogenéticas. Todas as espécies descritas apresentaram uma única RON localizada na posição média ou subterminal de um autossomo ou de um cromossomo sexual (CAMACHO et al., 1985; FOSSEY; LIEBENBERG, 1995; 
GONZÁLEZ-GARCÍA, et al., 1996; PAPESCHI; BRESSA, 2002; PAPESCHI et al., 2003; CATTANI et al., 2004; CASTANHOLE et al., 2008).

Em Belastomatidae, as RONs foram descritas nos telômeros dos cromossomos sexuais X e Y, (Belastoma oxyurum e B. micantulum), ou na região telomérica de um autossomo (Belostoma elegans) (PAPESCHI; BRESSA, 2002). Nos Coreidae, uma única RON está presente na região intersticial do maior autossomo em Carlisi wahlbergi (FOSSEY; LIEBENBERG, 1995) e Spartocera fusca (CATTANI; PAPESCHI, 2004). Nos Pentatomidae, uma única região organizadora do nucléolo foi detectada na posição mediana do maior autossomo em Nezara viridula (CAMACHO et al., 1985; PAPESCHI et al., 2003) ou na região telomérica do cromossomo X em Graphosoma italicum (GONZÁLEZGARCÍA et al., 1996).

Os Pentatomidae são um ótimo material de estudo e, ainda, há muitas questões a serem respondidas como, por exemplo, qual é a família, o número de lobos testiculares, número cromossômico, o sistema cromossômico sexual ancestral. Para melhor avaliação deste grupo, muitas outras espécies deverão ser avaliadas, assim como, outras técnicas deverão ser aplicadas.

\section{Agradecimentos}

À Dra. Sônia Maria Oliani do Laboratório de Morfologia, IBILCE/UNESP por permitir utilizar o microscópio para capturar as imagens, ao Dr. Luis Antônio Alves Costa do Departamento de Entomologia do Museu Nacional do Rio de Janeiro, RJ pela identificação dos insetos, a CAPES, FAPESP e FUNDUNESP pelo apoio financeiro.

\section{Referências}

CAMACHO, J.P.M.; BELDA, J.; CABRERO, J. Meiotic behaviour of the holocentric chromosomes of Nezera viridula (Insecta, Heteroptera) analyzed Cbanding and silver impregnation. Canc. J. Gent Cytol, v. 27, p. 490-497, 1985. 
CASTANHOLE, M.M.U.; PEREIRA, L.L.V.; SOUZA, H.V.; BICUDO, H.E.M.C.; COSTA L.A.A.; ITOYAMA, M.M. Heteropicnotic chromatin and nucleolar activity in meiosis and spermiogenesis of Limnogonus aduncus (Heteroptera, Gerridae): a stained nucleolar organizing region that can serve as a model for studying chromosome behavior, Genetics and Molecular Research, v. 7, n. 4, p. 1398-1407, 2008.

CATTANI, M.V.; PAPESCHI, A.G. Nucleolus organizing regions and semipersistent nucleolus during meiosis in Spartocera fusca (Thunberg) (Coreidae, Heteroptera). Hereditas, v. 140, p. 105-111, 2004.

CATTANI, M.V.; GREIZERSTEIN, E.J.; PAPESCHI, A.G. Male meiotic behaviour and nucleolus organizer regions in Camptischium clavipes (Fabr.) (Coreidae, Heteroptera) analyzed by florescent banding and in situ hybridization. Caryologia, v. 57, n. 3, p. 267-273, 2004.

COSTA, L.C.; AZEREDO-OLIVEIRA, M.T.V. de; TARTAROTTI, E. Spermatogenesis and nucleolar activity in Triatoma klugi (Triatomine, Heteroptera). Genetics and Molecular Biology, v. 31, n. 2, p. 438-444, 2008.

DALLAI, R.; LUPETTI, P.; FRATI, F.; NARDI F.; AFZELIUS B.A. Sperm ultrastructure and spermiogenesis in the relie species Tricholepidion gertschi Wygodzinsky (Insecta, Zygentoma). Tissue Cell, v. 33, p. 596-605, 2001.

FOSSEY, A.; LIEBENBERG, H. Meiosis and nucleolar structures in the stink bug Cartisis wahlbergi Stal (Coreidae: Heteroptera) Cytobios, v.81, p. 7-15, 1995.

GONZÁLEZ-GARCIA, J.M.; ANTONIO, C.; SUJA, J.A.; RUFAS, J.S. Meiosis in holocentric chromosomes: kinetic activity is randomly restricted to the chromatid ends of sex univalents in Graphosoma italicum (Heteroptera).

Chromosome Research, v. 4, p. 124-132, 1996.

GROZEVA, S.M.; KUZNETSOVA, V.G. The reproductive system of some bug families (Heteroptera, Pentatomomorpha).- In: Advances in Reproduction of Insect Reproduction (eds B. BENNETOVA, I. GELBIC and T. SOLDAN), Institute of Entomology, Czech Academy of Science, p. 97- 102, 1992. 
HOFGARTNER, F. J.; SCHMID, M.; KRONE, W.; ZENZES, M. T.; ENGEL, W. Pattern of activity of nucleolus organizers during spermatogenesis in mammals as analyzed by silverstaining. Chromosoma, v. 71, p. 197-216, 1979.

HOWELL W.M.; BLACK, D.A. Controlled silver-staining of nucleolus organizer regions with a protective colloidal developer: a 1-step method. Experientia, v. 36, p. 1014-1015, 1980.

LANZONE C.; SOUZA M.J.de. Chromosome complement and meiosis in three species of the Neotropical bug genus Antiteuchus (Heteroptera, Pentatomidae, Discocephalinae). Genet. Mol. Biol., vol. 29, n.1, p. 49-55, 2006.

MORIELLE A.; de AZEREDO-OLIVEIRA M.T.V. Description of the nucleolar activity and karyotype in germinative cell lines of Rhodnius domesticus (Triatominae, Heteroptera). Caryologia, v. 57, p. 31-37, 2004.

PAPESCHI, A.G; BRESSA, M.J. Cytogenetic studies in Belostomatidae from Argentina. Abstracts of the second quadrennial meeting of the International Heteropteristis Society, v. 46, 2002.

PAPESCHI, A.G.; MOLA, L.M.; BRESSA, M.J.; GREIZERSTEIN, E.J.; LÍA, V.; POGGIO, L. Behaviour of ring bivalents in holocentric systems: Alternative sites of spindle attachment in Pachylis argentinus and Nezara viridula (Heteroptera). Chromosome Research, v. 11, p. 725-733, 2003.

PEREZ R.; RUFAS J.S.; SUJA J.A.; PAGE J.; PANZERA F. Meiosis in Holocentric Chromosomes: Orientation and Segregation of an Autosome and Sex Chromosomes in Triatoma infestans (Heteroptera). Chromosome Research, v. 8, n. 1, p. 17-25, 2000.

REBAGLIATI, P.J.; MOLA, L.M.; PAPESCHI, A.G.; GRAZIA, J. Cytogenetics studies in Pentatomidae (Heteroptera): A review. J.Zool Syst Evol Res, v. 43, p. 199-213, 2005.

RUFAS J.S.; GOSÁLVEZ J. Development of silver stained structures during spermatogenis of Schistocerca gregaria (Forsk.) (Orthoptera: Acrididae).

Caryologia, v. 35, p. 261-267, 1982. 
SCHRADER, F. Regular occurrence of heteroploidy in a group of Pentatomidae (Hemiptera). Biol. Bull., v. 88, p. 63-70, 1945a.

SCHRADER, F. The cytology of regular heteroploidy in the genus Loxa (Pentatomidae - Hemiptera). J. Morphol., v.76, p.157-177, 1945 b.

SCHRADER, F. The elimination of chromosomes in the metiotic divisions of Brachystethus rubromaculatus Dallas. Biol. Bull., v. 90, p. 19-31, 1946 a.

SCHRADER, F. Autossomal elimination and preferential segregation in the harlequin lobe of certain Discocephalini (Hemiptera). Biol. Bull., v. 90, p. 264$290,1946 b$.

SCHRADER, F. Cytological and evolutionary implications of aberrant chromosome behavior in the harlequin lobe of some Pentatomidae (Heteroptera). Chromosoma, v. 11, p. 103-128, 1960a.

SCHRADER, F. Evolutionary aspects of aberrant meiosis in some Pentatomidae (Heteroptera). Evolution, v. 14, p. 498-508, 1960 b.

SOUZA, H. V.; BICUDO, H. E. M. C.; COSTA L. A. A.; ITOYAMA, M. M. A study of meiosis and spermiogenesis in the testicular lobes of Antiteuchus tripterus (Heteroptera, Pentatomidae). European Journal of Entomology, v. 104, p. 353-362, 2007a.

SOUZA, H. V.; BICUDO, H. E. M. C.; ITOYAMA, M. M. Study of chromosomal and nucleolar aspects in testes of Nysius californicus (Heteroptera, Lygaeidae). Genetics and Molecular Biology, v. 6, n. 1, p. 33-40, 2007 b.

SOUZA, H. V.; CASTANHOLE, M. M. U.; BICUDO, H. E. M. C.; COSTA L. A. A.; ITOYAMA, M. M. Morphological patterns of the heteropycnotic chromatin and nucleolar material in meiosis and spermiogenesis of some Pentatomidae (Heteroptera). Genetics and Molecular Biology, v. 31, n. 3, p. 686691, 2008.

SUJA, J. A.; de la TORRE, J.; GIMÉNEZ-ABIÁN, J. F.; GARCÍA de la VEGA, C.; 
RUFAS, J. S. Meiotic chromosome structure. Kinetochores and chromatid axes in standard and B-chromosomes of Arcyptera fusca (Orthoptera) revealed by silver staining. Genome, v. 34, p. 19-27, 1991.

SUMNER, A.T. Chromosome Banding. Unwin Hyman, London, 1990.

TARTAROTTI E.; AZEREDO-OLIVEIRA M.T.V. Patterns of nucleolar activity during spermatogenesis of two triatomines, Panstrongylus megistus and $P$. herreri. Caryologia, v. 52, p. 177-184, 1999. 

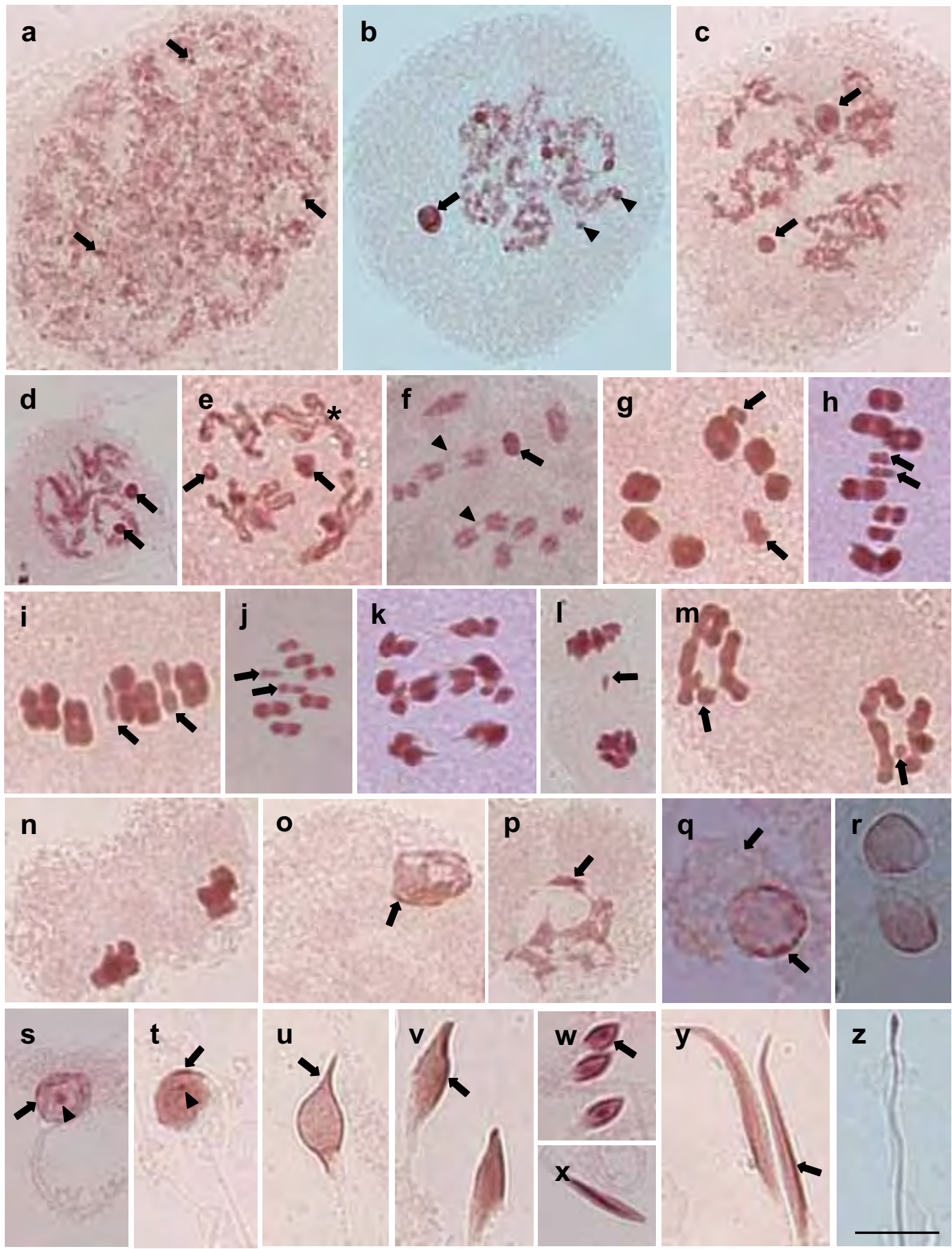

Figura 1. Células dos túbulos seminíferos de Edessa affins (b, h, k, q, r, z), Edessa meditabunda (a, c, e, g, i, m, n, o, p, t, u, v, y) e Thyanta perditor $(\mathrm{d}, \mathrm{f}, \mathrm{j}, 1, \mathrm{~s}, \mathrm{w}, \mathrm{x})$ (Pentatomidae) coradas com orceína lacto-acética. a) núcleo poliplóide com algumas regiões heteropicnóticas pequenas (setas); b) zigóteno-paquíteno com material heteropicnótico grande (seta) e vários pequenos (cabeça de seta); c,d) paquíteno com dois corpúsculos heteropicnóticos de tamanhos diferentes (setas); e,f) diplóteno com material heteropicnótico (setas), quiasmas (asteriscos) e associações teloméricas (cabeças de setas); g) metáfase I em visão polar apresentando cromossomos distribuídos aleatoriamente (as setas mostram os cromossomos sexuais); h-j) metáfase I de E. affins, E. meditabunda e T. perditor apresentando $2 \mathrm{n}=16(14 \mathrm{~A}+\mathrm{XY})(\mathrm{h}), 2 \mathrm{n}=14(12 \mathrm{~A}$ + XY) (i) e 2n= 14 (12A + XY) (j) cromossomos, respectivamente; k) anáfase; 1) anáfases I com migração tardia do cromossomo sexual (seta); $\mathrm{m}$ ) telófase; $\mathrm{n}-\mathrm{q}$ ) espermátides iniciais com material cromatínico (seta); r) espermátides arredondadas com material heteropicnótico na periferia do envoltório nuclear (seta) e central $(\mathrm{s}, \mathrm{t})$; $\mathrm{u}, \mathrm{v}, \mathrm{y})$ espermátides em alongamento com material heteropicnótico distribuído ao longo do comprimento (seta); w,x) espermátides em alongamento com material heteropicnótico arredondado (w) ou alongado (x) na região central da cabeça; z) espermatozóide em formação. Barra: $10 \mu \mathrm{m}$. 

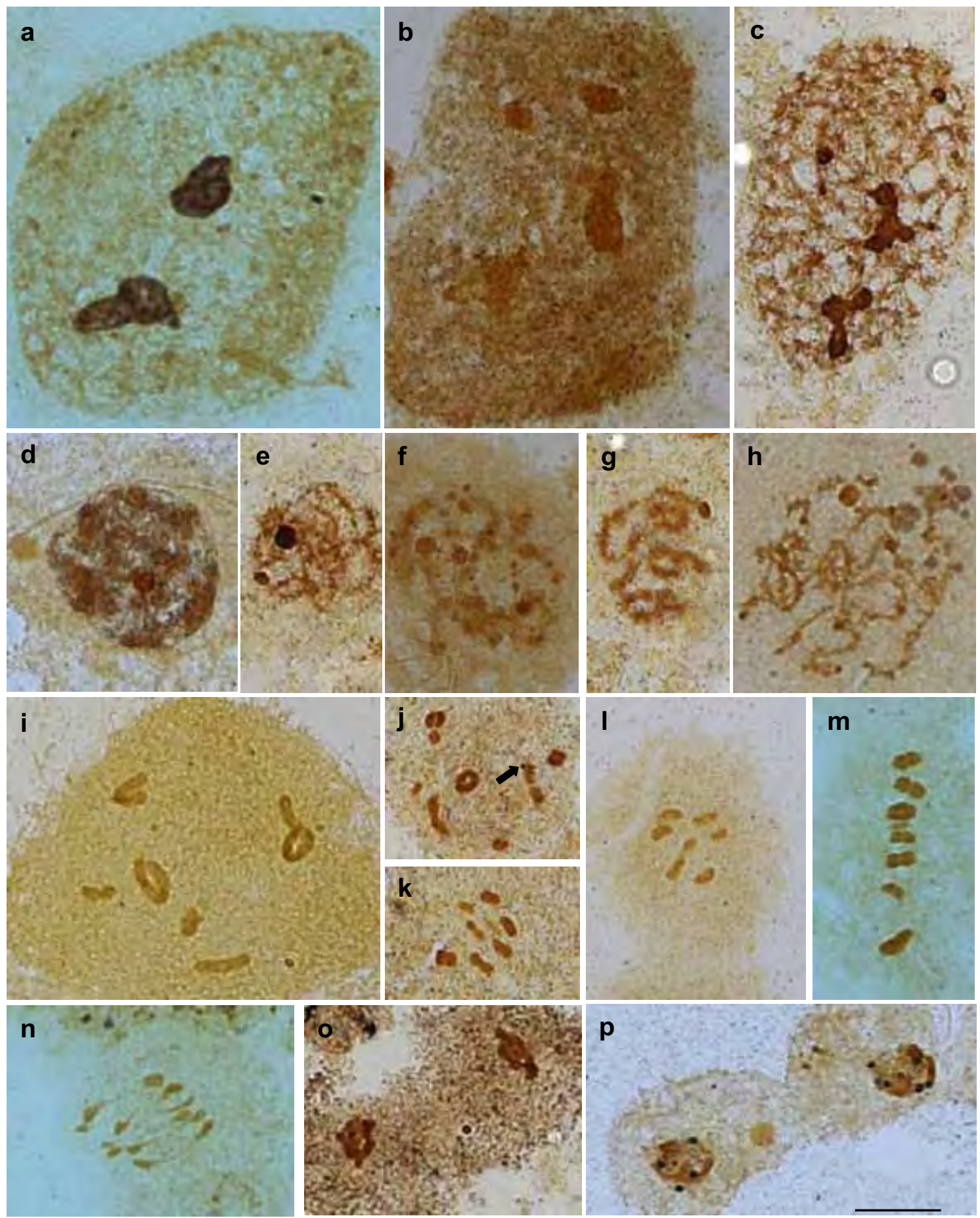

Figura 2. Células dos túbulos seminíferos de Edessa affins (lobos 2,3,4) (a, h, i, m), Edessa meditabunda (lobos 1, 2 e 3) (b, d, f, 1, p) e Thyanta perditor (c, e, g, j, k, n, o) (Pentatomidae) impregnadas por íons prata. a-c) núcleos poliplóides com marcações amórficas; d-h) prófase I com uma ou duas marcações em $T$. perditor $(\mathrm{e}, \mathrm{g})$ e uma ou duas marcações fortemente coradas e várias fracamente coradas E. affins, E. meditabunda (d,f,h); i-k) diacineses e metáfase de T. perditor com tênue marcação da RON em um dos cromossomos; l-n) metáfase e anáfase sem material nucleolar; $\mathrm{o}, \mathrm{p}$ ) telófase com vários corpúsculos prata positivo. Barra: $10 \mu \mathrm{m}$. 

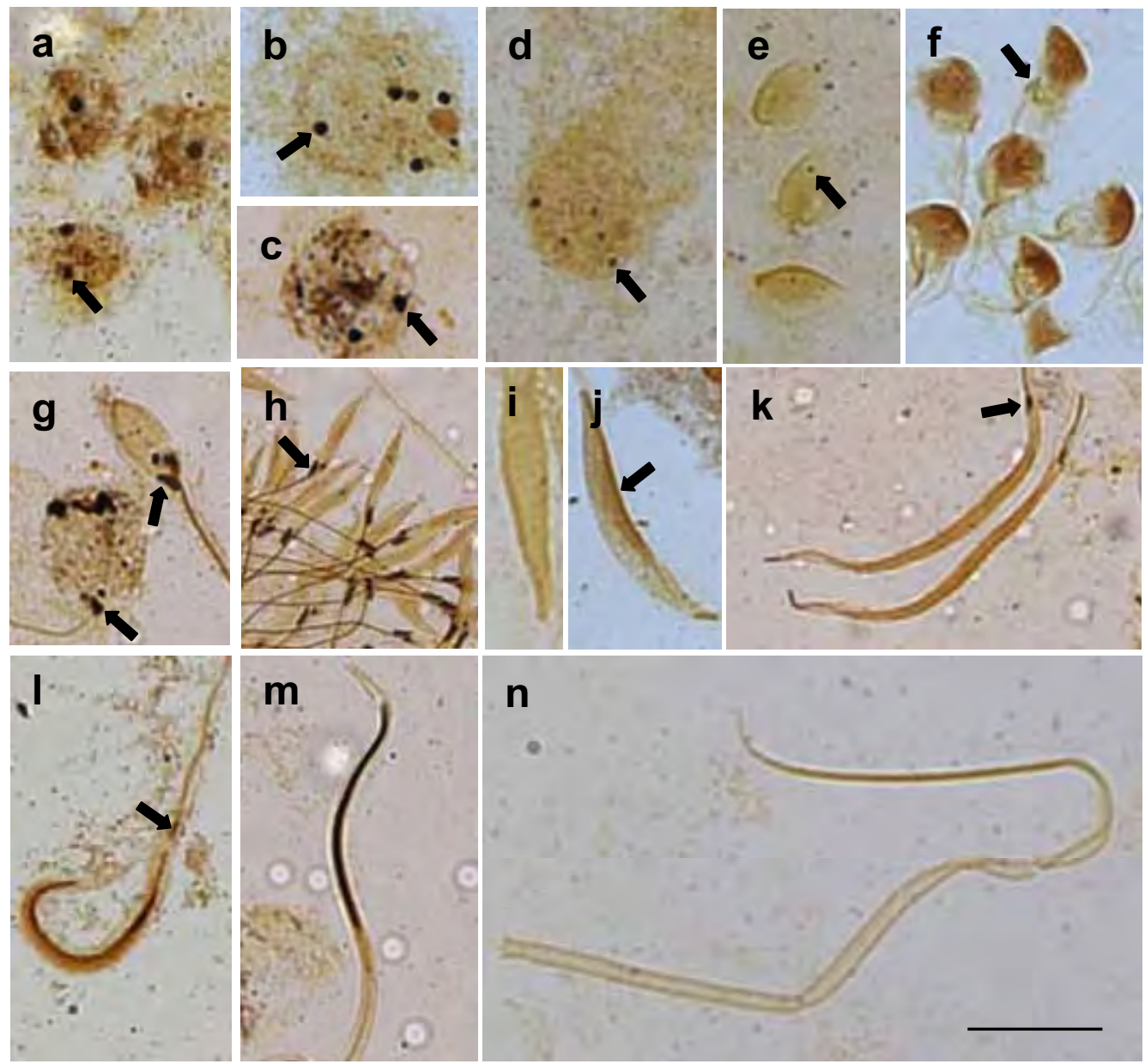

Figura 3. Células dos túbulos seminíferos de Edessa affins (lobos lobos 1, 2 e 3) (d, g, h, n), Edessa meditabunda (lobos lobos 1, 2 e 3) (b, f, i, j, $\mathrm{k}, 1, \mathrm{~m}$ ) e Thyanta perditor (a, c, e) (Pentatomidae) impregnadas por íons prata. a-d) espermátides com um ou mais corpúsculos impregnados; em) espermátides em alongamento apresentando um corpúsculo arredondado (e), marcação arredondada na região posterior da espermátide (f,g), marcações menos evidentes na região posterior e ao longo de todo comprimento em apenas um dos lados (h,j), na fase mais adiantada de alongamento podemos observar que $T$. perditor apresentou uma pequena marcação na região posterior e anterior (k), E. meditabunda possui marcação ao longo de toda espermátide (1) e E. affins a marcação foi bem evidente em toda região anterior da cabeça (m); n) espermatozóide em formação sem nenhuma marcação. Barra: $10 \mu \mathrm{m}$. 

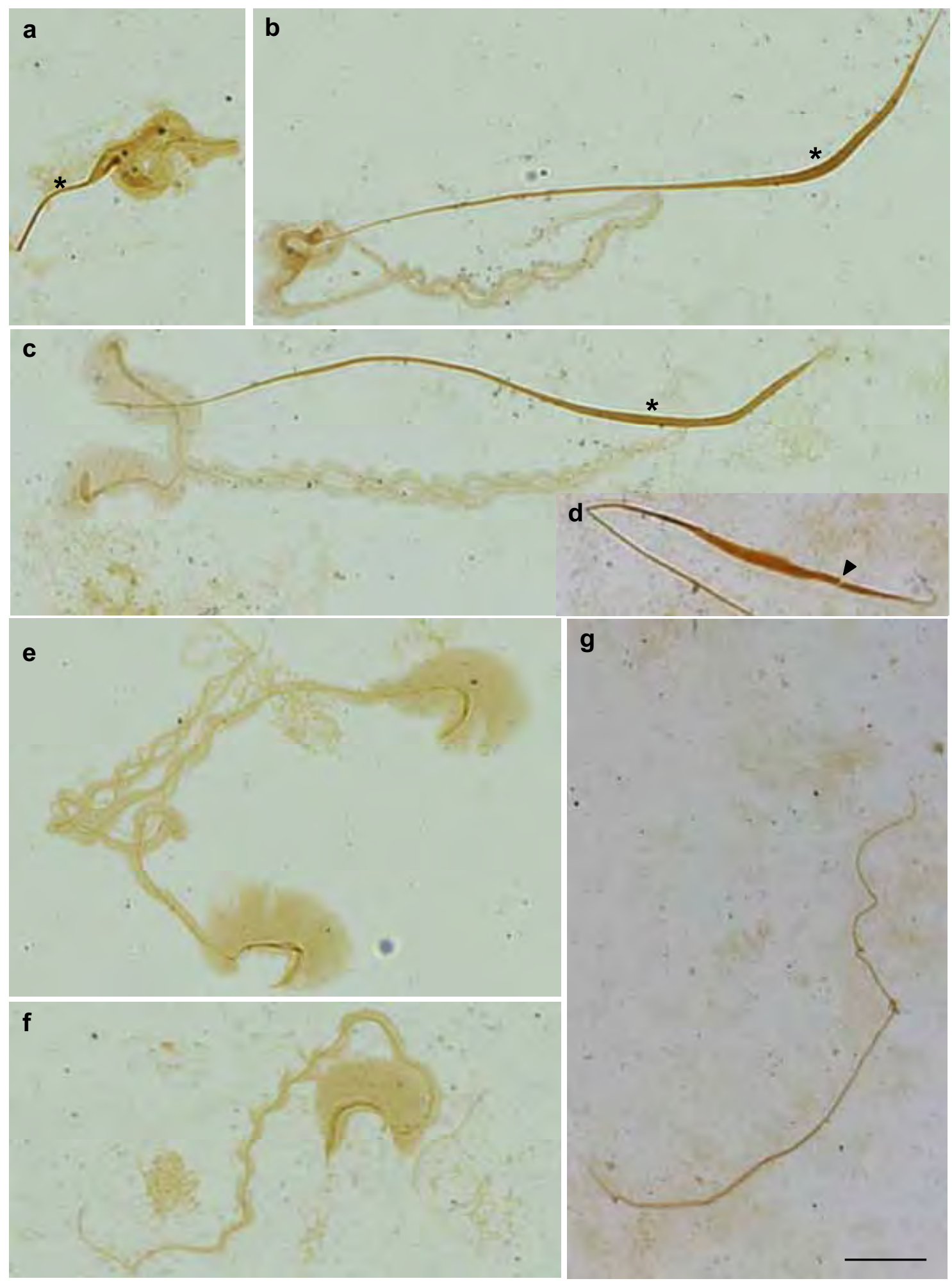

Figura 4. Células do lobo 4 de Edessa affins (Pentatomidae) impregnadas por íons prata. a-c) espermátides com formação diferenciada na cauda; d) espermátide com uma quebra (cabeça de seta); e,f) partes posteriores da cauda da espermátide que se separou da cabeça; g) espermátide em alongamento. Barra: $10 \mu \mathrm{m}$. 


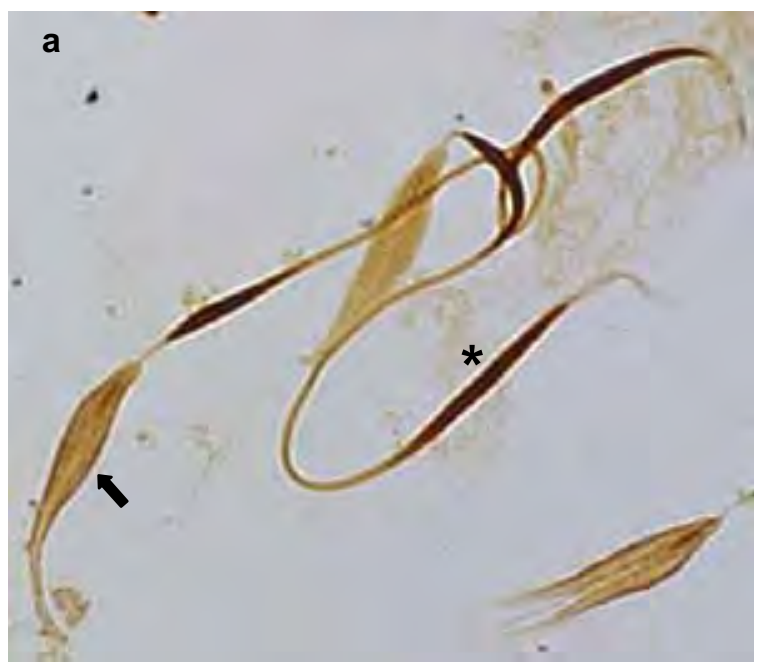

\section{b}

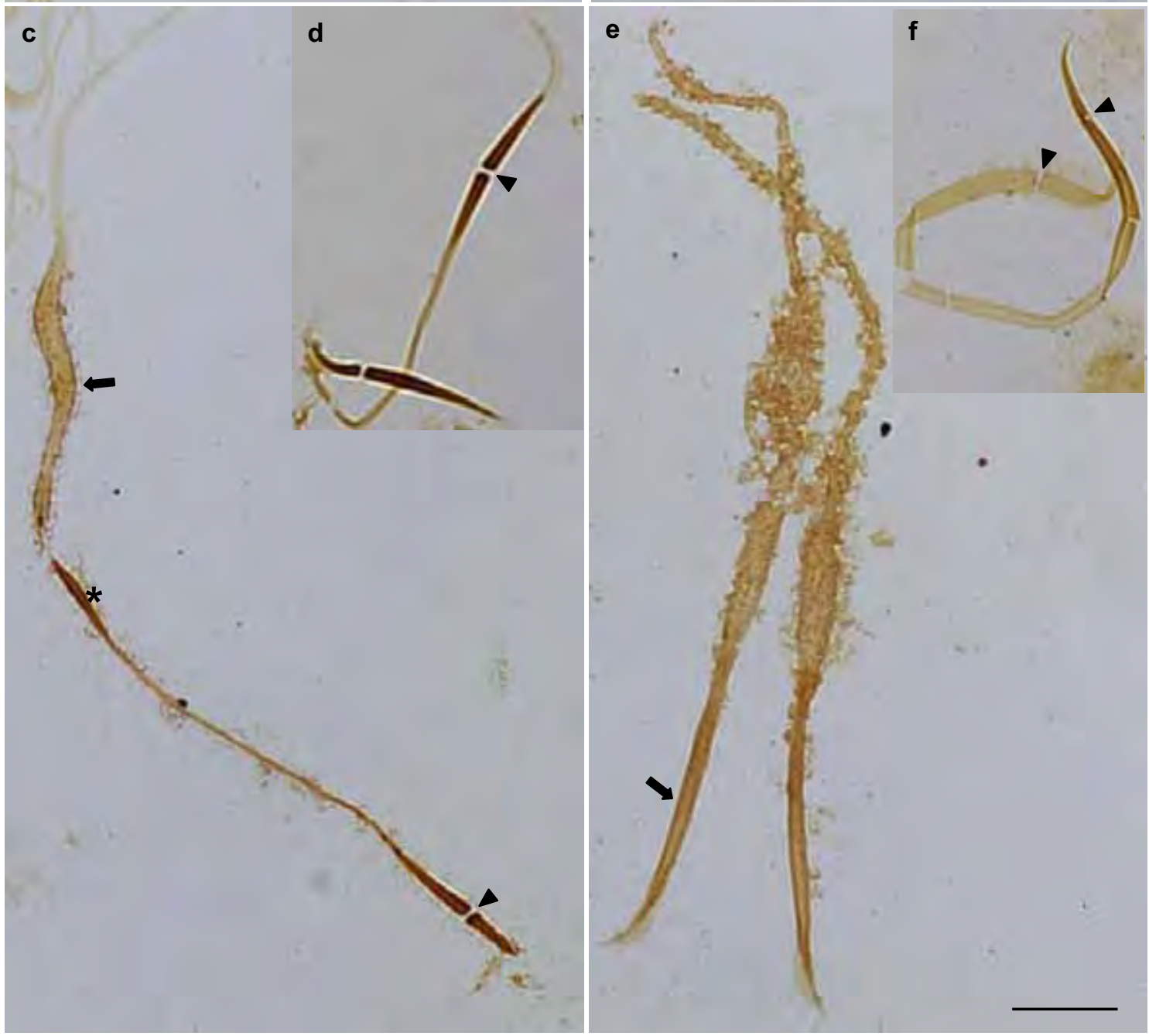

Figura 5. Células do lobo 4 de Edessa meditabunda (Pentatomidae) impregnadas por íons prata. a,b) espermátides com regiões da cabeça com o diâmetro aumentado, sendo 2 mais impregnadas e 1 menos; c,d) algumas dessas regiões sofrem fragmentações; e) a região menor impregnada parece formar vesículas; f) espermátides com regiões de fragmentações. Barra: $10 \mu \mathrm{m}$. 


\section{Semi-persistênca nucleolar em Atopozelus opsimus e Doldina carinulata (Heteroptera, Reduviidae, Harpactorinae)}

MURAKAMI, Aline Sumitani; CASTANHOLE, Márcia Maria Urbanin; ITOYAMA, Mary Massumi

UNESP-Universidade Estadual Paulista, Instituto de Biociências, Letras e Ciências Exatas, Departamento de Biologia, Laboratório de Citogenética e Molecular de Insetos-LACIMI

\section{Resumo}

Uma das subfamílias mais estudadas da família Reduviidae é a Triatominae (hematófagas), talvez isso se deva ao fato dela conter espécies de importância para a saúde humana (transmissoras da Doença de Chagas). Com relação às demais subfamílias, os estudos são mais escassos. Com o intuito de ampliar as informações citogenéticas dessas outras subfamílias da família Reduviidae, foram analisadas as espécies insetívoras Atopozelus opsimus e Doldina carinulata (Heteroptera, Reduviidae, Harpactorinae). A. opsimus apresentou 2n= $26(24 \mathrm{~A}+$ $\mathrm{XY})$ e D. carinulata $2 \mathrm{n}=27\left(24 \mathrm{~A}+\mathrm{X}_{1} \mathrm{X}_{2} \mathrm{Y}\right)$ cromossomos. Pelas descrições da literatura com relação às espécies hematófagas, chegou-se à conclusão, que essas espécies insetívoras apresentam comportamentos meióticos semelhantes, isto é, possuem cromossomos holocêntricos, a primeira divisão meiótica dos autossomos é reducional e dos cromossomos sexuais é equacional, apresentam quiasmas terminais ou intersticiais, os cromossomos de associam telomericamente e as células em prófase apresentam material heteropicnótico. Com relação à espermiogênese, o comportamento das espécies analisadas no presente trabalho são semelhantes. As espermátides iniciais são arredondadas, posteriormente se alongam (elípticas), com a presença de material heteropicnótico próximo ao envoltório da célula. Com relação ao comportamento do material prata positivo durante a espermatogênese nas duas espécies, observou-se semi-persistência nucleolar. Com relação à espermiogênese, após impregnação por íons prata, 
poucos são os dados relacionados aos Reduviidae para podermos comparar com as Harpactorinae, mas este processo é bastante diferente entre os Heteroptera e mesmo espécies da mesma subfamília apresentam resultados distintos aos obtidos neste trabalho, onde as espermátides em alongamento de $D$. carinulata apresentaram cabeça em forma de "V" e altamente impregnadas pelos íons prata.

\section{Palavras-chave: cromossomos holocêntricos, espermatogênese, corpúsculo heteropicnótico, semi-persistência nucleolar}

\section{Introdução}

Entre os Heteroptera, a família Reduviidae destaca-se por apresentar espécies insetívoras e hematófagas sendo, portanto, de grande importância para a agricultura e saúde humana, pois podem transmitir a doença de Chagas durante a hematofagia. Por serem de maiores dimensões que os demais percevejos predadores, os reduviídeos consomem não só um maior número, como também, um maior espectro de espécies de presas (PANZERA et al., 1992). Além destas características, as espécies pertencentes a esta família apresentam interesse citogenético adicional por possuírem cromossomos holocêntricos que se caracterizam pela presença de um centrômero difuso ou não localizado (HUGLES-SCHRADER; SCHRADER, 1961). As informações sobre a evolução destes cromossomos na literatura são escassos, pois devido a falta de um centrômero morfologicamente diferenciado e a falta de diferenciação cromossômica longitudinal há dificuldade de detectar variação estrutural. Por estas razões os rearranjos cromossômicos, tais como inversões e translocações recíprocas são raramente relatados em Heteroptera (PAPESCHI; MOLA, 1990; BRESSA et al., 1998). A família Reduviidae é constituída por 12 subfamílias, sendo a Triatominae a que apresenta hematofagia. Esta subfamília é caracterizada por possuir número diplóide de $2 \mathrm{n}=22(20 \mathrm{~A}+\mathrm{XY})$ (UESHIMA, 1966; PANZERA et al., 1996; MORIELLE; AZEREDO-OLIVEIRA, 2004). 
Uma outra subfamília da família Reduviidae é a Harpactorinae. Se compararmos as duas subfamílias veremos que a Triatominae é muito mais estudada citogeneticamente do que a Harpactorinae, que possui somente 7 espécies analisadas. As espécies da subfamília Harpactorinae descritas na literatura apresentaram número médio de $2 \mathrm{n}=28\left(24 \mathrm{~A}+\mathrm{X}_{1} \mathrm{X}_{2} \mathrm{X}_{3} \mathrm{Y}\right)$ cromossomos (UESHIMA, 1979). Objetivando contribuir para a melhor caracterização citogenética da subfamília Harpactorinae nós analisamos alguns aspectos da espermatogênese (meiose e espermiogênese) e do comportamento nucleolar em Atopozelus opsimus e Doldina carinulata.

\section{Materiais e Métodos}

Quinze machos adultos de cada espécie de Atopozelus opsimus e Doldina carinulata (Reduviidae, Harpactorinae) foram coletados no município de São José do Rio Preto-SP (2047'32"S, 49²1'37"W) em pés de capixingui (Croton floribundus) e ipê-amarelo (Tabeluia sp). Após a coleta foram eterizados e dissecados, já que a espermatogênese em Heteroptera não se encerra no estágio de ninfa. Os testículos extraídos foram colocados e dilacerados em lâminas e corados com orceína lacto-acética ou impregnados por íons prata segundo protocolo modificado de Howell e Black (1980), para o estudo citogenético da meiose, espermiogênese e impregnação por íons prata. As amostras que não foram utilizadas logo após a coleta foram fixadas em metanol:ácido-acético (3:1) e mantidas a $8^{\circ} \mathrm{C}$. As lâminas foram analisadas no microscópio de luz Olympus modelo BX40 do Laboratório de Citogenética e Molecular de Insetos (LACIMI) e as melhores imagens foram capturadas no microscópio de luz AXIOSKOP 2 ZEISS (programa AXIOVISION) do laboratório de Morfologia, do Departamento de Biologia do IBILCE/UNESP, São José do Rio Preto - SP. 


\section{Resultados}

\section{Observação dos testículos após coloração com orceína lacto-acética}

Após dissecação das amostras de Atopozelus opsimus e Doldina

carinulata (insetívoro, Reduviidae), observamos que os testículos são arredondados e envoltos por membrana branca ou alaranjada, respectivamente. Quando rompida, libera 7 lobos, que são alongados e estão ligados a uma única região central, semelhantemente a um "ofiuróide".

As análises das células espermatogoniais das 2 espécies de Reduviidae foram semelhantes e por esse motivo estão sendo apresentados em conjunto. Os núcleos poliplóides de ambas as espécies apresentaram várias regiões heteropicnóticas e são maiores que as células meióticas (Figura 1a).

Durante a espermatogênese de D. carinulata, observamos que as células meióticas em leptóteno-zigóteno apresentam 3 corpúsculos heteropicnóticos que, possivelmente, são os cromossomos sexuais $\mathrm{X}_{1} \mathrm{X}_{2} \mathrm{Y}$ (Figura 1b). Já $A$. opsimus apresenta 2 corpúsculos heteropicnóticos arredondadas que, também, possivelmente são os cromossomos sexuais XY (Figura 1c,d). Esses corpuscúlos podem estar bem próximos (Figura 1c) ou mais distantes (Figura 1d).

Quando os cromossomos começaram a se condensar, observamos a presença de alguns quiasmas e finos filamentos unindo-os (Figura 1e). A medida que os cromossomos se condensaram mais, a união entre eles foi mais evidente, formando um único grupo de cromossomos em forma de " $Z$ " (Figura 1f). No final da prófase, houva a separação e individualização dos cromossomos homólogos (Figura 1g,h), permitindo verificar, na metáfase I, que o complemento cromossômico de $D$. carinulata é de $2 \mathrm{n}=27\left(24 \mathrm{~A}+\mathrm{X}_{1} \mathrm{X}_{2} \mathrm{Y}\right)$ (Figura 1i) e de A. opsimus é de $2 \mathrm{n}=26(24 \mathrm{~A}+\mathrm{XY})$ (Figura $1 \mathrm{j}, \mathrm{k})$.

Nas anáfases, observamos migração uniforme dos cromossomos (Figura 11). Nas telófases, os autossomos se dispõem circularmente, ficando os cromossomos sexuais no seu centro (Figura $1 \mathrm{~m}$ ). Ao final do processo meiótico, 
formam-se espermátides grandes com cromatina descondensada e com uma vesícula grande ao lado da cromatina (Figura 1n).

A espermiogênese se inicia com espermátides arredondadas com material heteropicnótico na periferia do envoltório nuclear em forma de meia lua (Figura 1o,p). No estágio mais avançado, as espermátides elípticas vão se alongando e o material heteropicnótico é observado por todo o seu comprimento (Figura 1q-t), mais fortemente, em apenas um dos lados da cabeça e na região posterior da mesma. No final do processo não se evidencia material heteropicnótico na região posterior da cabeça (Figura 1u).

\section{Observação dos testículos após impregnação por íons prata}

Após análises das células impregnadas por íons prata observamos que durante a meiose as duas espécies apresentaram comportamentos semelhantes. Por este motivo serão descritos em conjunto. Durante a meiose, observamos que as células meióticas em leptóteno apresentam um pequeno corpúsculo prata positivo (Figura 2a). Já em zigóteno-paquíteno, observa-se um grande corpúsculo prata positivo fortemente corado que, possivelmente, seja o nucléolo (Figura 2b,c). No final da prófase, o corpúsculo prata positivo começa a se desorganizar (Figura 2d). Durante a metáfase, observamos em alguns cromossomos material prata positivo ao redor da bainha pericromossômico (Figura 2e). As espécies D. carinulata e de A. opsimus apresentaram semipersistência nucleolar, o que pode ser comprovada na Figura $2 \mathrm{f}$-h. Durante a anáfase, o corpúsculo nucleolar migra para apenas uma das células (Figura 2 i-1).

Como mencionado anteriormente, o comportamento das células meióticas de $D$. carinulata e de A. opsimus, após impregnação por íons prata, foram semelhantes, o que não aconteceu com as células durante a espermiogênese. Pelo fato dos resultados terem sido diferentes, os mesmos serão apresentados separadamente. As espermátides de $A$. opsimus recém formadas apresentam um corpúsculo prata positivo arredondado e algumas regiões da bainha pericromossômica também impregnadas (Figura 2m-n). Com o desenvolvimento, 
as marcações cromossômicas vão diminuindo e o tamanho da espermátide também (Figura 2o-q). Com o alongamento das espermátides, o corpúsculo prata positivo começa a se deslocar para a região posterior da cabeça (Figura 2r) que com o desenvolvimento tornam-se mais tênues (Figura 2s).

Inicialmente, as marcações pela prata nas espermátides arredondadas de $D$. carinulata são semelhantes as de $A$. opsimus, isto é, há um ou dois corpúsculos arredondados prata positivo e algumas regiões cromossômicas marcadas (Figura 3a-c). Com o alongamento da espermátide, a região anterior da cabeça torna-se mais corada, sendo a mais próxima do material cromatínico, mais corado, e em forma de "ponto de interrogação invertido" (Figura 3d). Esta região começa a se alongar ficando a porção mais corada na extremidade final da espermátide (Figura 3e). Numa fase subseqüente, esse material começa a se desorganizar em estruturas menores (Figura 3f) e, nas fases subseqüentes, não se observa mais nenhuma marcação, somente uma expansão alongada na região anterior da cabeça (Figura 3g,h). Quando as espermátides estão mais alongadas, observa-se nesta região expandida o início de depósito de material impregnado pela prata, que vai se acentuando com o alongamento da espermátide (Figura 3ip). Na última fase do alongamento das espermátides que conseguimos observar, elas possuem a região expandida da cabeça em forma de "V", com a parte externa mais impregnada e pode-se observar, ainda, os filamentos da cauda na parte interna do "V" (Figura 3o). Estes filamentos também apresentam marcação prata positiva (Figura $3 p)$.

\section{Discussão}

Uma das características comuns entre todos os Heteroptera é que eles possuem testículos formados por lobos alongados e estão sempre um ao lado do outro, podendo variar de três a sete (SOUZA et al., 2007). As espécies analisadas apresentaram 7 lobos e os mesmos não estão dispostos lado a lado como o das outras famílias de Heteroptera. Eles estão ligados por uma única região que se assemelha a um ofiuróide, contudo não há relatos na literatura que 
justifiquem este tipo de morfologia. Todas as espécies de Reduviidae já descritas possuem o testículo com essa morfologia, o que deve ser uma característica dessa família.

Os Heteroptera, além de possuírem ampla diversidade e serem uma das maiores subordens, também apresentam cromossomos holocêntricos, isto é, sem centrômero localizado, associação telomérica, primeira divisão meiótica dos autossomos reducional e dos cromossomos sexuais equacional, migração tardia na anáfase, presença de quiasmas terminais e intersticiais (UESHIMA, 1979; SOUZA et al., 2007, 2008; CASTANHOLE et al., 2008; COSTA et al., 2008), assim como os analisados no presente trabalho.

O número cromossômico modal da família Reduviidae é $2 \mathrm{n}=22$ $(20 \mathrm{~A}+\mathrm{XY})$ cromossomos (COSTA et al., 2008, PANZERA et al., 1996, 1998). As duas espécies analisadas no presente trabalho não apresentaram esse número cromossômico modal $\left(\right.$ D. carinulata $=27,24 \mathrm{~A}+\mathrm{X}_{1} \mathrm{X}_{2} \mathrm{Y}$ e A. opsimus $=26,24 \mathrm{~A}$ $+\mathrm{XY})$. As espécies da subfamília Harpactorinae descritas na literatura apresentam $2 \mathrm{n}=28\left(24 \mathrm{~A}+\mathrm{X}_{1} \mathrm{X}_{2} \mathrm{X}_{3} \mathrm{Y}\right)$, mostrando que esta subfamília não é conservada evolutivamente. Há necessidade, também, de análise de um maior número de espécies para se chegar ao número cromossômico padrão, assim como para a definição do sistema cromossômico do sexo, já que as espécies descritas na literatura apresentaram $\mathrm{X}_{1} \mathrm{X}_{2} \mathrm{X}_{3} \mathrm{Y}$ e as analisadas no presente trabalho apresentaram sistemas $\mathrm{X}_{1} \mathrm{X}_{2} \mathrm{Y}$ e $\mathrm{XY}$.

Uma outra característica observada em Heteroptera, que também foi observado no presente trabalho, é a presença de material heteropicnótico durante a prófase meiótica (PANZERA et al., 1995; COSTA et al., 2008; SOUZA et al., 2007, 2008; CASTANHOLE et al., 2008) que são, geralmente, composto pelos cromossomos sexuais. Entretanto, isto não é regra, pois foi observado em Belastoma dentatum autossomos bivalentes em condensação contínua, enquanto ambos cromossomos sexuais estavam descondensados e negativamente heteropicnóticos durante a diacinese (PAPESCHI e BIDAU, 1985).

Após impregnação por íons prata, D. carinulata e A. opsimus apresentou corpúsculos nucleolares nas metáfases, anáfases e telófases sendo este 
comportamento denominado de semi-persistência nucleolar (TARTAROTTI; AZEREDO-OLIVEIRA, 1999). Isto evidencia que o nucléolo não desaparece completamente durante a meiose em triatomíneos, mas reorganiza-se de elementos nucleolares pré-existentes (SOUZA et al., 2008). A impregnação pela prata vem contribuindo para a descrição do comportamento nucleolar durante a espermatogênese (TARTAROTTI; AZEREDO-OLIVEIRA, 1999), podendo-se evidenciar que o aumento de corpúsculos nucleolares pode estar relacionado com o aumento da síntese de RNAr (TAVARES; AZEREDO-OLIVEIRA, 1997).

Algumas características estruturais da meiose têm sido atribuídas a efeito ambiental. Há autores que atribuem a semi-persistência nucleolar a esse efeito, como é o caso de Cattani e Papeschi (2004) em Spartocera fusca (Heteroptera). Segundo esses autores, a semi-persistência do nucléolo, nessa espécie, foi detectada em indivíduos que demoraram mais tempo no campo e foram expostos a fatores tais como flutuações ambientais de temperatura, umidade e precipitação.

Entretanto, alguns autores sugerem que impregnação por íons prata pode, também, revelar outras estruturas cromossômicas. Em Schistocerva gregária (Orthoptera), a impregnação por prata revelou material cinetocórico ou centromérico nas espermátides iniciais enquanto nas espermátides em alongamento as estruturas prata positivas foram atribuídas a um material relacionado à condensação da cromatina. Na meiose a prata revelou marcação em três estruturas distintas: região organizadora nucleolar, cinetócoro e cors (SUJA et al., 1991). Portanto, há necessidade de outras avaliações, a outros níveis, para se chegar à conclusão do que é composto este material que se impregna pela prata.

\section{Agradecimentos}

À Dra. Sônia Maria Oliani do Laboratório de Morfologia, IBILCE/UNESP por permitir utilizar o microscópio para capturar as imagens, ao Dr. Hélcio Gil Santana do Instituto Oswaldo Cruz, RJ pela identificação dos insetos, a CAPES, FAPESP e FUNDUNESP pelo apoio financeiro. 


\section{Referências}

BRESSA, M.J.; PAPESCHI, A.G.; MOLA, L.M.; LARRAMENDY, M.L. Meiotic studies in Largus rufipennis (Castelnau) (Largidae, Heteroptera). II Reciprocal translocation heterozygosity. Caryologia, v. 51, n. 3-4, p. 253-264, 1998.

CASTANHOLE, M.M.U.; PEREIRA, L.L.V.; SOUZA, H.V.; BICUDO, H.E.M.C.; COSTA L.A.A.; ITOYAMA, M.M. Heteropicnotic chromatin and nucleolar activity in meiosis and spermiogenesis of Limnogonus aduncus (Heteroptera, Gerridae): a stained nucleolar organizing region that can serve as a model for studying chromosome behavior, Genetics and Molecular Research, v. 7, n. 4, p. 1398-1407, 2008.

CATTANI M.V.; PAPESCHI A.G. Nucleolus organizing regions and semipersistent nucleolus during meiosis in Spartocerca fusca (Coreidae, Heteroptera), Hereditas, v. 140, p. 105-111, 2004.

COSTA, L.C.; AZEREDO-OLIVEIRA, M.T.V. de; TARTAROTTI, E. Spermatogenesis and nucleolar activity in Triatoma klugi (Triatomine, Heteroptera). Genetics and Molecular Biology, v. 31, n. 2, p. 438-444, 2008.

HOWELL W.M.; BLACK, D.A. Controlled silver-staining of nucleolus organizer regions with a protective colloidal developer: a 1-step method. Experientia, v. 36, p. 1014-1015, 1980.

HUGHES-SHCRADER, S.; SHCRADER, F. The Kinetochore of the Hemiptera. Chromosoma, v. 12, p. 327-350, 1961. 
MORIELLE A.; de AZEREDO-OLIVEIRA M.T.V. Description of the nucleolar activity and karyotype in germinative cell lines of Rhodnius domesticus (Triatominae, Heteroptera). Caryologia, v. 57, p. 31-37, 2004.

PANZERA F.; ALVAREZ F.; SANCHEZ-RUFAS J.; PEREZ R.; SUJA J.A.; SCVORTZOFF E.; DUJARDIN J.P.; ESTRAMIL E.; SALVATELLA R. Cheterochromatin polymorphism in holocentric chorosomes of Triatoma infestans (Hemiptera: Reduviidae). Genome, v. 35, p.1068-1074, 1992.

PANZERA F.; PEREZ R.; PANZERA Y.; ALVAREZ F.; SCVORTZOFF E.;SALVATELLA R. Karyotype evolution in holocentric chromosomes of three related species of Triatominae (Hemiptera: Reduviidae). Chrom Res, v. 3, p. 143150, 1995.

PANZERA F.; PEREZ R.; HORNOS S.; PANZERA Y.; CESTAU, R.; DELGADO V.; NICOLINI P. Chromosome numbers in the Triatominae (Hemiptera-Reduviidae): a review. Mem. Inst. Oswaldo Cruz, v. 91, p. 515-518, 1996.

PANZERA F.; SCVORTZOFF E.; PÉREZ R.; PANZERA Y.; HORNOS S.; CESTAU R.; NICOLINI P.; DELGADO V.; ALVAREZ F.; MAZZELLA M.; COSSIO G.; MARTÍNEZ M.; SALVATELLA R. Citogenetics of triatomines, $p$. 621-664. In R Carcavallo, Atlas de Triatominos de América, Fundação Oswaldo Cruz, Rio de Janeiro,1998.

PAPESCHI, A.G.; BIDAU C.J. Chromosome complement and male meiosis in four species of Belastoma Latreille (Heteroptera-Belostomatidae). Rev. Brasil. Genet. VIII, v. 2, p. 249-261, 1985. 
PAPESCHI, A.G.; MOLA, L.M. Meiotic studies in Acanonicus hahni (Coreidae, Heteroptera). I. Behaviour of univalents in desynaptic individuals. Genetica, v. 80, p. 31-38, 1990.

SOUZA, H. V.; BICUDO, H. E. M. C.; COSTA L. A. A.; ITOYAMA, M. M. A study of meiosis and spermiogenesis in the testicular lobes of Antiteuchus tripterus (Heteroptera, Pentatomidae). European Journal of Entomology, v. 104, p. 353-362, 2007.

SOUZA, H. V.; CASTANHOLE, M. M. U.; BICUDO, H. E. M. C.; COSTA L. A. A.; ITOYAMA, M. M. Morphological patterns of the heteropycnotic chromatin and nucleolar material in meiosis and spermiogenesis of some Pentatomidae (Heteroptera). Genetics and Molecular Biology, v. 31, n. 3, p. 686691, 2008.

SUJA, J. A.; de la TORRE, J.; GIMÉNEZ-ABIÁN, J. F.; GARCÍA de la VEGA, C.; RUFAS, J. S. Meiotic chromosome structure. Kinetochores and chromatid axes in standard and B-chromosomes of Arcyptera fusca (Orthoptera) revealed by silver staining. Genome, v. 34, p. 19-27, 1991.

TARTAROTTI E.; AZEREDO-OLIVEIRA M.T.V. Patterns of nucleolar activity during spermatogenesis of two triatomines, Panstrongylus megistus and $P$. herreri. Caryologia, v. 52, p. 177-184, 1999.

TAVARES, M. G.; AZEREDO-OLIVEIRA, M.J.V. Pattern of nucleolar activity during spermatogenesis in triatomines (Heteroptera: Reduvidae) as analysed by silver staining. Cytobios, v. 89, p. 93-103, 1997.

UESHIMA N. Cytotaxonomy of the Triatominae (Reduviidae: Hemiptera). Chromosoma, v. 18, p. 97-122, 1966. 
UESHIMA, N. Animal cytogenetics, Insecta 6, Hemiptera: Heteroptera.

Gebruder Borntraeger: Berlin, Stuttgart, 1979. 

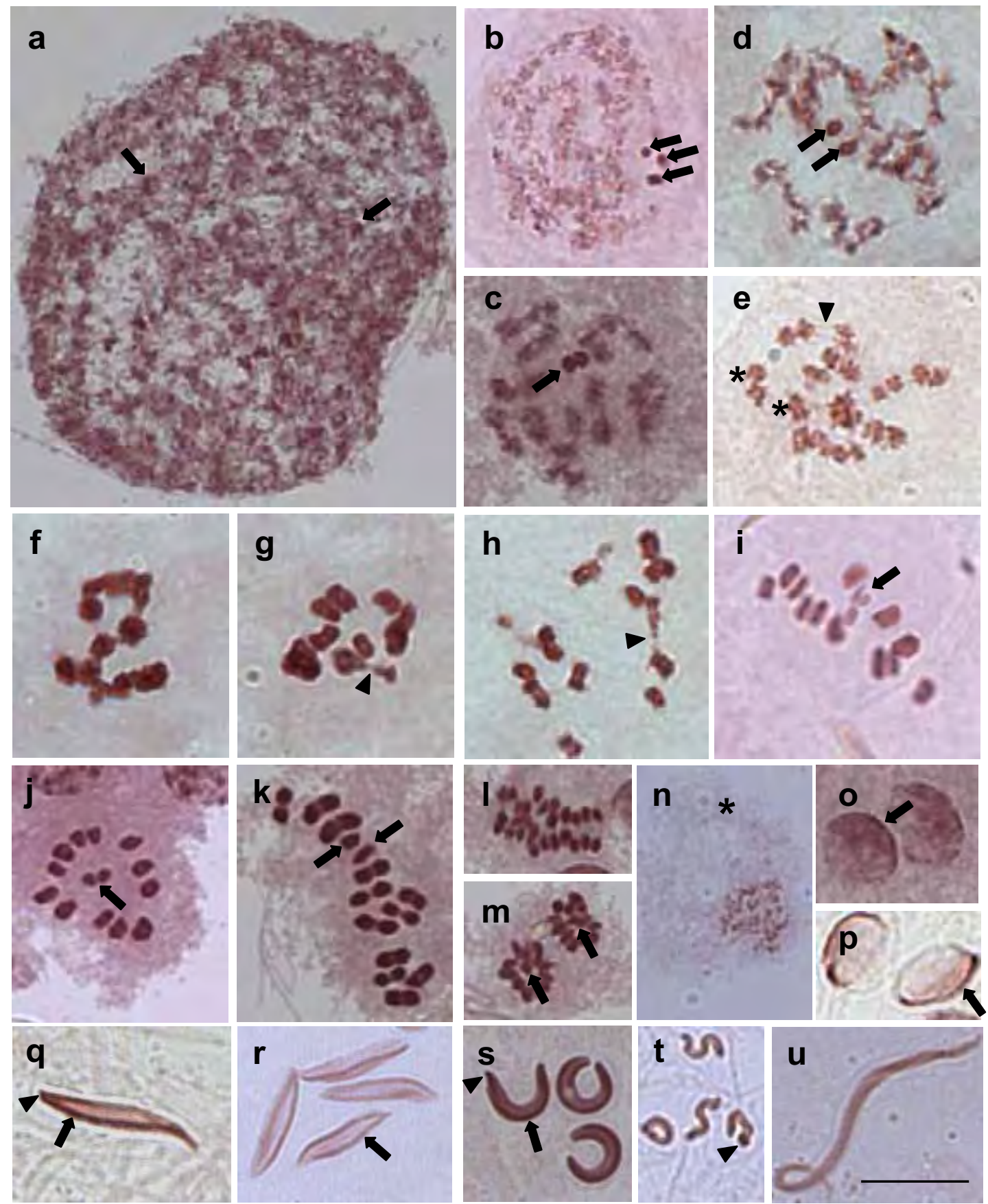

Figura 1. Células dos túbulos seminíferos de Atopozelus opsimus (a, c, j, k, l, m, n, o, r, s, t, u) e Doldina carinulata (b, d, e, f, g, h, i, p, q) (Reduviidae) coradas com orceína lacto-acética. a) núcleo poliplóide com várias regiões heteropicnóticas; b-d) leptóteno-zigóteno com três ou duas regiões heteropicnóticas arredondadas que possivelmente são os cromossomos sexuais (setas); e) paquíteno, apresentando alguns cromossomos com quiasmas (asteriscos) e alguns filamentos unindo os cromossomos (cabeça de seta); f) células apresentando cromossomos unidos pela região telomérica, apresentando morfologia de "Z"; g,h) cromossomos em diferentes fases de condensação apresentando, ainda, algumas regiões de união (cabeça de seta); i) metáfase I de D. carinulata mostrando os cromossomos distribuídos aleatoriamente e os cromossomos sexuais com a morfologia de uma "pata" apresentando 24 autossomos e 3 cromossomos sexuais $\left.\left(\mathrm{X}_{1} \mathrm{X}_{2} \mathrm{Y}\right) ; \mathrm{j}\right)$ metáfase $\mathrm{I}$ de $A$. opsimus apresentando $2 \mathrm{n}=26(24 \mathrm{~A}+\mathrm{XY})$ cromossomos; $\mathrm{k}$ ) metáfase I em visão lateral (as setas mostram os cromossomos sexuais); 1) anáfase; $\mathrm{m}$ ) telófase evidenciando os cromossomos sexuais no centro formado por autossomos (setas); n) espermátide recém formada onde podemos observar um vesícula grande (asterisco); o,p) espermátides arredondadas com material heteropicnótico na periferia do envoltório nuclear; q-t) espermátides em alongamento com material heteropicnótico em todo o comprimento em apenas um dos lados (seta) e na região posterior (cabeça de seta); u) espermátide em alongamento não sendo mais possível observar material heteropicnótico. Barra: $10 \mu \mathrm{m}$. 

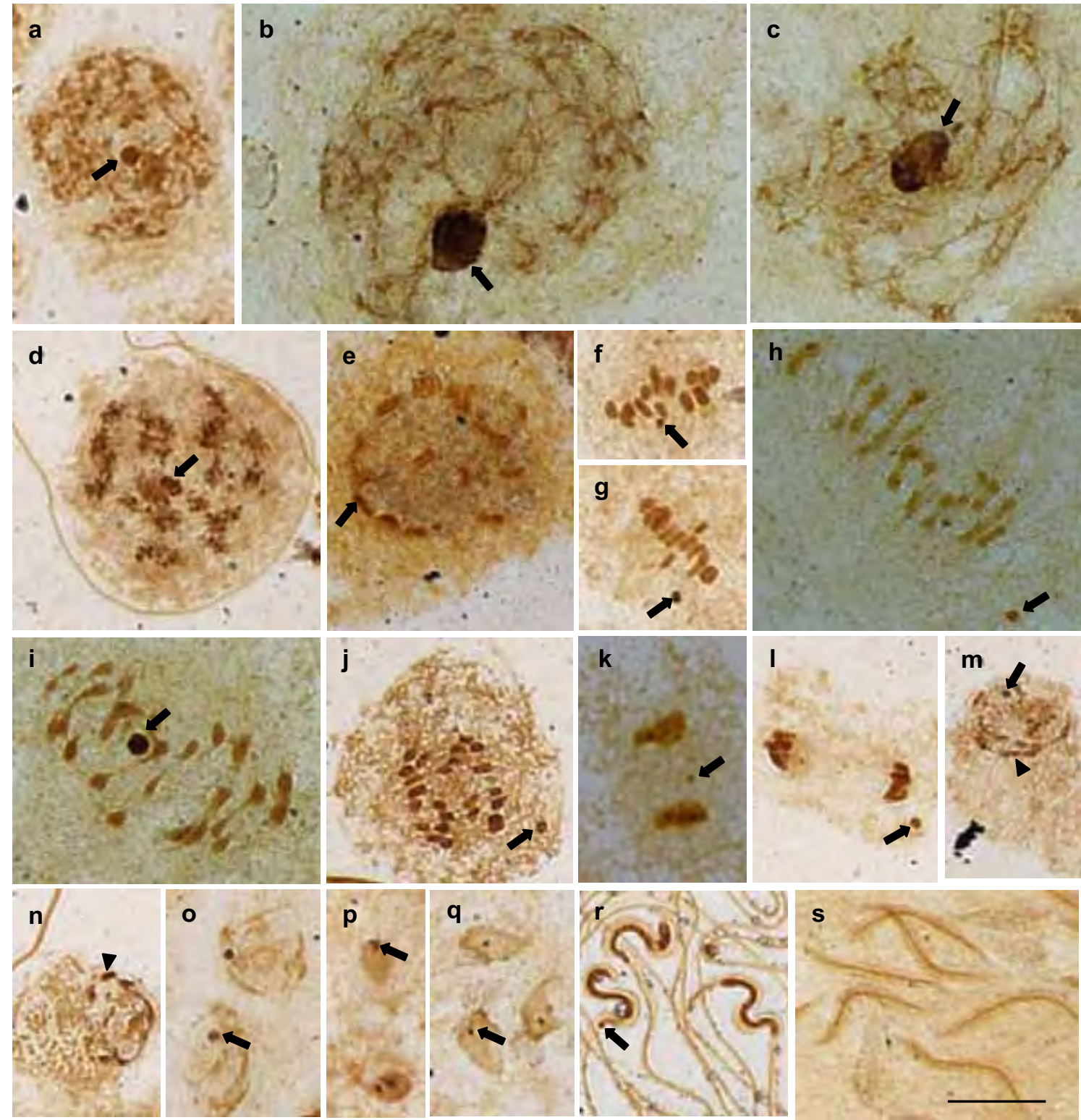

Figura 2. Células dos túbulos seminíferos de Atopozelus opsimus (a, d, f, g, j, l, m, n, o, p, q, r, s) e Doldina carinulata (b, c, e, h, i, k) (Reduviidae) impregnadas por íons prata. a) leptóteno com um pequeno corpúsculo heteropicnótico; b,c) zigóteno-paquíteno com um grande corpúsculo fortemente corado; d,e) diplóteno-diacinese com desorganização do corpúsculo; f-h) metáfase com semi-persistência nucleolar (seta); i-1) anáfases com a presença do corpúsculo nucleolar (seta); m,n) espermátide recém-formada com um pequeno corpúsculo (seta) e algumas regiões da bainha pericromossômica impregnadas pela prata (cabeça de seta); o,q) espermátides arredondadas com uma pequena região impregnada pela prata (seta); r) espermátides em alongamento com o corpúsculo na região posterior da cabeça; s) espermatozóides em formação. Barra: $10 \mu \mathrm{m}$. 

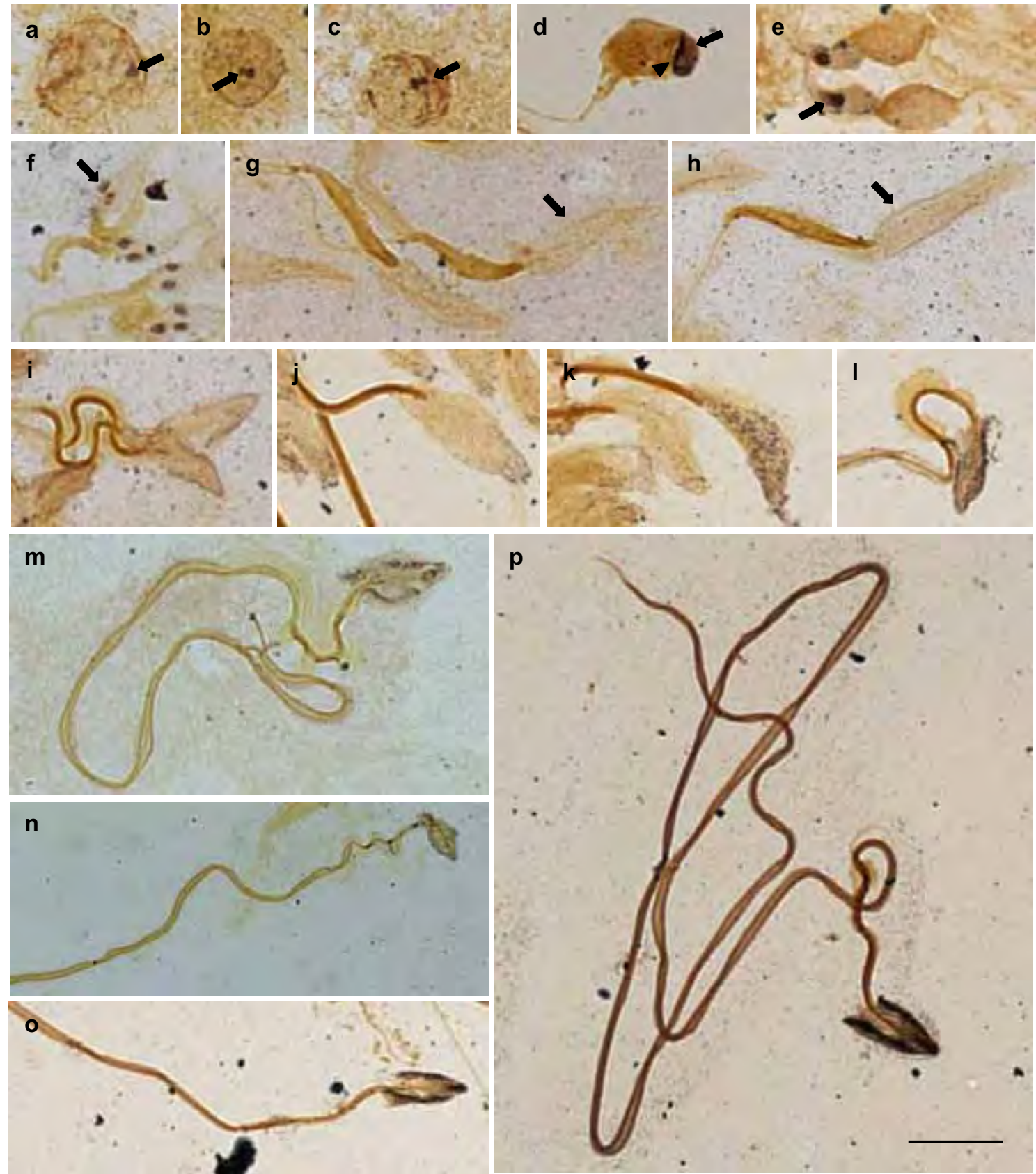

Figura 3. Células dos túbulos seminíferos de Doldina carinulata (Reduviidae) impregnadas por íons prata. a-c) espermátides arredondadas com 1 ou 2 corpúsculos prata positivo (setas) e, também, algumas regiões cromatínicas impregnadas; d) espermátides em alongamento com região anterior da cabeça intensamente marcada (seta), sendo a mais próxima da cromatina em forma de "ponto de interrogação invertido" (cabeça de seta); com o alongamento da espermátide visualiza-se, nesta região, somente um corpúsculo prata positivo (e, seta); com o alongamento estes corpúsculos começam a se desorganizar (f); g,h) as espermátides em alongamento apresentam uma expansão alongada na região da cabeça (setas). Observar na região expandida o início de depósito de material prata positivo (i-o); p) espermátide alongada com forte impregnação na região expandida em forma de "V" e em toda a cauda. Barra: $10 \mu \mathrm{m}$. 
IV. DISCUSSÃO GERAL 


\section{DISCUSSÃO GERAL}

No presente trabalho, foi analisada a espermatogênese (comportamento meiótico e espermiogênese) através da técnica de coloração com orceína lacto-acética e impregnação por íons prata de uma espécie da Alydidae (Stenocoris (Oryzocoris) furcifera), três de Coreidae (Acanonicus hahni, Acantocephala sp. e Anisoscelis foliacea marginella), cinco de Pentatomidae (Chlorocoris complanatus, Edessa affins, Edessa meditabunda, Loxa deducta e Thyanta perditor) e duas de Reduviidae (Atopozelus opsimus e Doldina carinulata).

Uma das características comuns entre todos os Heteroptera é que eles possuem testículos formados de lobos e que são alongados e estão sempre um do lado do outro. O número é variável, de três a sete (SOUZA et al., 2007a). Segundo a literatura o número de lobos na família Lygaeidae varia, tendo sido encontrados indivíduos com dois, quatro, seis e sete lobos, sendo sete considerado o número ancestral (GROZEVA; KUZNETSOVA, 1992). As subfamílias Arthencinae, Oxycareninae e alguns Lygaeinae como Paranysius fraterculus possuem o menor número de lobos, somente dois (GROZEVA; KUZNETSOVA, 1992). Nysius californicus (Lygaeidae) apresenta 7 lobos envoltos por uma membrana avermelhada. Este número de lobos a coloca entre as espécies portadoras das características ancestrais, segundo Souza et al. (2007b). Mormidae v-luteum, Oebalus poecilus e O. ypisilongrisus (Pentatomidae, Pentatominae) possuem 3, 4 e 4 lobos, respectivamente, (SOUZA et al., 2008). Antiteuchus tripterus (Pentatomidae, Pentatominae) possui 6 lobos sendo o sexto interno ao quinto (SOUZA et al., 2007a).

Segundo Souza et al. (2007b), as espécies de Coreidae (Anasa bellator, Athaumastus haematicus, Chariesterus armatus, Dallacoris obscura, D. pictus, Leptoglossus gonagra, L. zonatus, Sphictyrtus fasciatus e Zicca annulata) apresentam testículos constituídos de sete lobos, envoltos por uma membrana avermelhada com exceção de Zicca annulata e Chariesterus armatus, as quais apresentaram quatro lobos e coloração da membrana, respectivamente, amarelada 
e translúcida. Com relação à família Alydidae não há informações na literatura referentes a estas características.

As espécies de Coreidae analisadas no presente trabalho apresentaram sete lobos e membrana alaranjada ou avermelhada e a espécie de Alydidae apresentou 6 lobos e membrana vermelha, as espécies de Pentatomidae Chlorocoris complanatus e Loxa deducta (Pentatominae) apresentaram sete lobos, Edessa affins e E. meditabunda (Edesseinae) quatro lobos e Thyanta perditor (Pentatominae) três lobos. As espécies da família Reduviidae (Atopozelus opsimus e Doldina carinulata) apresentaram sete lobos. Com relação ao número de lobos, não há como concluirmos qual é o número de lobos ancestral, se esta característica está ou não relacionada à família, pois o número de espécies analisadas é muito pequeno. Portanto, a análise de um maior número de espécies e famílias será de extrema importância para o entendimento desta característica.

Uma outra característica observada no presente trabalho, é que somente em espécies da família Reduviidae os lobos testiculares estavam ligados por uma única região que se assemelha a um ofiuróide, em vez de se encontrarem dispostos lado a lado como nas demais famílias. Não há relatos na literatura que justifiquem este tipo de morfologia. Até o ponto que temos conhecimento, todas as espécies de Reduviidae analisadas possuem o testículo com essa morfologia.

Uma outra característica que somente algumas espécies da família Pentatomidae apresentam é a presença de um lobo com características diferentes dos demais, denominado de lobo harlequin. As subfamílias que, geralmente apresentam este lobo são a Edessinae, a Pentatominae e a Discocephalinae. Segundo Rebagliati et al. (2005), a presença destes lobos poderia estar relacionada com o meio ambiente no qual esses insetos vivem. Entretanto, estudos com Antiteuchus tripterus (Pentatomidae) não parece corroborar essa idéia porque exemplares coletados em diferentes Estados do Brasil, com ambientes bastantes diferentes (São Paulo, SOUZA et al., 2007a; Pernambuco, Alagoas e Bahia, LANZONE; SOUZA, 2006) revelaram a presença do lobo em ambos os locais, sugerindo, assim, que se trata de uma característica do gênero Antiteuchus, antes que ser um efeito ambiental. 
Dos quinze gêneros estudados com a presença do lobo harlequin em Pentatomidae, 11 pertencem a subfamília Discocephalinae, 3 pertencem a Pentatominae, Loxa, Mayrinia e Adevoplitus e 1 pertence a Edessinae, Brachystethus rubromaculatus (REBAGLIATI et al., 2005). Portanto, das oito subfamílias existentes (Aphylinae, Asopinae, Cyrtocorinae, Discocephalinae, Edessinae, Pentatominae, Phyllocephalinae e Podopinae), segundo Schuh e Slater (1995), somente três (Discocephalinae, Edessinae e Pentatominae) possuem este lobo.

Segundo Schrader (1945a,b; 1946a,b), o lobo harlequin não possui ocorrência acidental ou esporádica nas espécies possuidoras. Eles são encontrados em todos os testículos e em todos os machos de uma dada espécie e é sempre o mesmo lobo. Em Discocephalinae, por exemplo, geralmente é o lobo 5, contado a partir do ducto ejaculatório, o harlequin. A espécie Antiteuchus tripterus (Heteroptera, Pentatomidae, Discocephalinae) analisada por Souza et al. (2007a), também apresenta seis lobos testiculares, sendo o 5 o harlequin.

Das cinco espécies (C. complanatus, E. affins, E. meditabunda, L. deducta e T. perditor) de Pentatomidae analisadas no presente trabalho somente C. complanatus e L. deducta apresentaram o lobo harlequin, sendo este o quinto, assemelhando-se as espécies descritas na literatura. Portanto, parece que todas as espécies que apresentam lobo harlequin, este sempre é o quinto. Uma outra característica observada nos lobos harlequin, é que o comportamento das células também diferem das células de outros lobos, principalmente durante a metáfase/anáfase. Nestas fases os cromossomos podem ser visualizados condensados ou descondensados, como as espécies analisadas neste trabalho ou descondensados como em Antiteuchus tripterus (SOUZA et al., 2007a). Pelas informações obtidas, não há condições de supormos nenhuma hipótese com relação a este tipo de comportamento.

As espécies analisadas no presente trabalho pertencentes às subfamílias Edessinae (E. affins e E. meditabunda) e Pentatominae (T. perditor) não apresentaram o lobo harlequin, apesar de estas subfamílias caracterizarem-se por apresentá-los. Apesar de não terem este lobo, a espermiogênese do lobo 4 de 
E. meditabunda e E. affins foi diferente dos demais. Talvez este possa ser um processo intermediário para a formação de espermatozoides não-fecundantes.

Os Heteroptera, além de possuírem ampla diversidade e ser uma das maiores subordens também possuem cromosomos holocêntricos, isto é, sem centrômero localizado, migração tardia na anáfase, presença de quiasmas terminais e intersticiais (UESHIMA, 1979; SOUZA et al., 2007a; CASTANHOLE et al., 2008; COSTA et al., 2008). As espécies Stenocoris (Oryzocoris) furcifera (Alydidae), Acatocephala sp, Acanonicus hahni e Anisoscelis foliacea marginella (Coreidae), Chlorocoris complanatus, Edessa affins, Edessa meditabunda e Loxa deducta (Pentatomidae) e Atopozelus opsinus e Doldina carinulata (Reduviidae) também apresentaram estas características, portanto estas características devem ser comum a todos os Heteroptera.

Uma outra característica observada em Heteroptera é a presença de material heteropicnótico durante a prófase meiótica (PANZERA et al., 1995; COSTA et al., 2008; SOUZA et al. 2007a, 2008; CASTANHOLE et al., 2008) e, geralmente, composto pelos cromossomos sexuais, como também observado no presente trabalho. Entretanto, isto não é regra, pois foi observado em Belastoma dentatum autossomos bivalentes em condensação contínua, enquanto ambos cromossomos sexuais estavam descondensados e negativamente heteropicnóticos durante a diacinese (PAPESCHI; BIDAU, 1985).

Com relação ao número de autossomos em Heteroptera ele varia de quatro (Belostomatidae) a 80 (Miridae), mas estes números não são típicos para a subordem (UESHIMA, 1979). É difícil de dizer qual é o número cromossômico modal para a subordem inteira, pois todas as oito infraordens maiores dentro dos Heteroptera foram estudadas citologicamente na mesma extensão (GROZEVA; NOKKALA, 1996).

Com relação aos sistemas cromossômicos de sexo já foram descritos: os simples $\mathrm{XY} / \mathrm{XX}(74,7 \%$ das espécies), $\mathrm{X} 0 / \mathrm{XX}(14,8 \%)$, e os múltiplos (originados por fragmentação do cromossomo $\mathrm{X}$ e, menos frequentemente, do cromossomos $\mathrm{Y}, \mathrm{Xn} 0 / \mathrm{XnXn}, \mathrm{XnY} / \mathrm{XnXn}$ e XYn/XX) (10,3\%) 
(UESHIMA, 1979; MANNA, 1984). Há ainda, um sistema particular Neo-XY (CHICKERING, BACORN, 1933; SCHRADER, 1940; JANDE 1959).

A maioria das espécies de Coreidae, descrita na literatura, apresentam número diploide de 21 cromossomos $(18 \mathrm{~A}+2 \mathrm{~m}+\mathrm{X} 0)$ (aproximadamente 48\% das 100 espécies já analisadas) (UESHIMA, 1979; SANDS, 1982; MANNA, 1984; COLOMBO; BIDAU, 1985; DEY; WANGDI, 1988; SATAPATHY; PATNAIK, 1989; CATTANI et al., 2004; SOUZA et al., 2007b). As espécies de Coreidae analisadas no presente trabalho apresentaram 19 (Acanonicus hahni), 21 (Acantocephala sp.) e 27 (Anisoscelis foliacea marginella) cromossomos, portanto, somente $A$. sp., parece apresentar o número cromossômico ancestral da família. Uma outra característica que quase todas as espécies apresentam é o sistema cromossômico do sexo X0. Todas as espécies, desta família, analisadas no presente trabalho, possuem esse sistema. Uma diferença observada e que não é comum para esta família é a ausência de mcromossomos apresentada por A. hahni. Esta espécie, cromossomicamente, é mais semelhante com as de Alydidae, já que a revisão da literatura nos mostra um complemento cromossômico de $2 \mathrm{n}=13(12 \mathrm{~A}+\mathrm{X} 0)$, confirmada pela espécie analisada no presente trabalho.

Os Pentatomidae apresentam número diploide de $2 \mathrm{n}=14$ cromossomos, sistema cromossômico do sexo $\mathrm{XY} / \mathrm{XX}$ e não possuem mcromossomos (SOUZA et al., 2007a; SCHRADER, 1946a,b, 1960a,b; REBAGLIATTI et al., 2005). As espécies C. complanatus, L. deducta, E. affins, E. meditabunda e $T$. perditor, analisadas no presente trabalho, também apresentaram o mesmo complemento cromossômico. A única exceção foi E. affins que apresentou $2 \mathrm{n}=16$ cromossomos.

As espécies da família Reduviidae descritas na literatura apresentam $2 \mathrm{n}=22(20 \mathrm{~A}+\mathrm{XY})$ cromossomos (COSTA et al., 2008; PANZERA et al., 1996, 1998), principalmente as da subfamília Triatominae. As da Harpactorinae descritas na literatura apresenta número modal de $2 \mathrm{n}=28(24 \mathrm{~A}+$ $\mathrm{X}_{1} \mathrm{X}_{2} \mathrm{X}_{3} \mathrm{Y}$ ). As espécies analisadas no presente trabalho não apresentaram este padrão $\left(D\right.$. carinulata $=27,24 \mathrm{~A}+\mathrm{X}_{1} \mathrm{X}_{2} \mathrm{Y}$ e A. opsimus $\left.=26,24 \mathrm{~A}+\mathrm{XY}\right)$, 
mostrando que esta subfamília não é conservada evolutivamente. Há necessidade, também, de análise de um maior número de espécies para se chegar ao número cromossômico padrão, assim como para a definição de sistema cromossômico do sexo, já que as espécies descritas na literatura apresentam sistema $\mathrm{X}_{1} \mathrm{X}_{2} \mathrm{X}_{3} \mathrm{Y}$ e as analisadas no presente trabalho apresentaram sistema $\mathrm{X}_{1} \mathrm{X}_{2} \mathrm{Y}$ e $\mathrm{XY}$.

$\mathrm{Na}$ literatura, discute-se a origem dos complementos cromossômicos constituídos de maior número de cromossomos a partir do menor número por duplicação ou fragmentação de um dos pares de autossomos (UESHIMA, 1980). Segundo Jacobs (2004), pelo fato dos Heteroptera apresentarem cromossomos holocêntricos, a fragmentação é o processo mais provável, porque origina segmentos que podem migrar regularmente para os polos durante a anáfase e sobreviver por muitas gerações celulares. Da mesma maneira, a fusão cromossômica é também teoricamente mais fácil em organismos com cromossomos holocêntricos, segundo o mesmo autor.

Seguindo esse raciocínio, as espécies $A$. foliacea marginella e $A$. hahni (Coreidae), analisadas no presente trabalho, com 27 e 19 cromossomos, respectivamente, poderiam ter se originado de uma espécie ancestral constituída de 21 cromossomos por fragmentação de autossomos e a espécie com número inferior por fusão cromossômica. A confirmação desta hipótese requer ainda, muitos estudos.

A técnica de impregnação pelos íons prata, desenvolvida por Howell e Black (1980) cora especificamente proteínas que se associam com o RNAr após sua transcrição. A cor marrom escura apresentada pelo material nucleolar, em decorrência desse processo, torna possível detectar sua presença e acompanhar suas modificações ao longo de um período da vida celular. Por este motivo, vem sendo utilizado a muitos anos.

Com relação ao comportamento nucleolar durante a divisão celular, há algumas descritas na literatura, por exemplo, artrópodes é usual a dissociação do nucléolo no diplóteno ou diacinese, o que faz com que o mesmo não possa ser detectado entre a metáfase e a telófase. Nesse período, porém, em alguns organismos é possível detectar a localização das regiões organizadoras 
nucleolares (RONs). Estas são as regiões cromossômicas onde se aloja o DNA ribossômico responsável pela síntese do RNAr cujas proteínas permanecem coradas com íons prata. Também é usual que quando as espermátides começam a se formar, os corpúsculos nucleolares reaparecem, desaparecendo novamente no final da formação dessas células reprodutivas (BRESSA et al., 2003).

Nos Heteroptera têm sido detectadas situações diferentes da descrita, em que, no final da prófase e na metáfase meiótica, o material prata positivo continua a ser visível. Este é o caso de Antiteuchus tripterus (Pentatomidae), que mostra material nucleolar nas referidas fases, associado ou em torno da bainha pericromossômica, sendo que, no início da telófase o corpúsculo nucleolar se recompõe (Souza et al., 2007a). Em testículo de Nysius californicus (Lygaeidae), verificou-se a presença de material prata positivo desde a célula cística até o espermatozóide completamente diferenciado (Souza et al., 2007b). Em Triatoma brasiliensis e T. sordida (Reduviidae), corpúsculos corados com Ag-NOR permanecem observáveis até a metáfase I (TAVARES, AZEREDO-OLIVEIRA, 1997). No Coreidae Carlisis wahlbergi, Fossey e Liebenberg (1995) observaram esses corpúsculos até a metáfase II. Em Mormidae quinqueluteum, Oebalus poecillus e O. ypsilongriseus (Pentatomidae) o material prata positivo foi observado durante a espermatogênese, inclusive durante as metáfases, sendo denominado de semi-persistência nucleolar (SOUZA et al., 2008).

As espécies analisadas no presente trabalho mostraram comportamentos diferentes do material nucleolar. Por exemplo, em $S$. (Oryzocoris) furcifera (Alydidae), A. foliacea marginella e A. hahni (Coreidae), o material nucleolar foi encontrado em toda meiose, na metáfase foi observado na bainha pericromossômica. Em C. complanatus, E affins, E. meditabunda e $T$. perditor não foi observado material durante a metáfase. A semi-persistência nucleolar foi observada em L. deducta, D. carinulata e A. opsimus. Portanto, podemos verificar que os comportamentos nucleolares são bastante diferentes entre as espécies e que necessitam de mais estudos para a conclusão. 
Há algumas explicações, para a semi-persistência nucleolar, há autores que atribuem a semi-persistência nucleolar ao efeito ambiental, como é o caso de Cattani e Papeschi (2004) em Spartocera fusca (Heteroptera). Segundo esses autores, a semi-persistência do nucléolo, nessa espécie, foi detectada em indivíduos que demoraram mais tempo no campo e foram expostos a fatores tais como flutuações ambientais de temperatura, umidade e precipitação.

$\mathrm{O}$ número e a localização das RONs foram determinadas em poucas espécies de Heteroptera por diferentes técnicas e diferentes resultados foram relatados. Todas as espécies descritas apresentaram uma única RON localizada na posição média ou subterminal de um autossomo ou de um cromossomo sexual (CAMACHO et al., 1985; FOSSEY; LIEBENBERG, 1995; GONZÁLEZ-GARCÍA, et al., 1996; PAPESCHI; BRESSA, 2002; PAPESCHI et al., 2003; CATTANI et al., 2004; CASTANHOLE et al., 2008). Das 11 espécies analisadas no presente trabalho, somente A. hahni e T. perditor apresentaram marcação em um autossomo. Há algumas explicações para a não visualização da RON. Segundo Camacho et al. (1985), Fossey e Liebenberg (1995); Castanhole et al. (2008), talvez isto se deva ao fato da característica holocêntrica dos cromossomos e pelo alto nível de condensação dos mesmos.

Trabalhos relacionados com o comportamento das células durante a espermiogênese, após impregnação por íons prata, são raros. Foi observado, por exemplo, em espécies de Panstrongylus (Heteroptera) que as marcações são visualizadas somente até a espermátide inicial (arredondada) desaparecendo durante a sua elongação (TARTAROTTI; AZEREDOOLIVEIRA, 1999). Esse processo foi observado também em mamíferos e outros vertebrados (HOFGARTNER et al., 1979; SUMNER, 1990). Em Nysius californicus (Heteroptera, Lygaeidae) as marcações pela prata foram observadas em todas as fases da espermiogênese: nas espermátides arredondadas estavam localizadas na periferia do envoltório nuclear, na alongada e nos espermatozóides, na região posterior da cabeça (SOUZA et al., 2007b), assim como em Limnogonus aduncus (CASTANHOLE et al., 2008), Antiteuchus tripterus (SOUZA et al., 
2008), Mormidae quinqueluteum, Oebalus poecilus e O. ypsilongreseus (SOUZA et al., 2008).

De modo geral, todas as espécies analisadas no presente trabalho apresentaram material marcado pela prata durante a espermiogênese, diferindo apenas com relação à localização, tamanho, forma e intensidade de coloração. A presença deste material prata positivo talvez não seja indicativo de material nucleolar, pois há, também, a possibilidade de que estas estruturas impregnadas pela prata sejam, por exemplo, alguma organela como a mitocôndria, ou o complexo de Golgi, ou corpo cromatóide (CB), estrutura esta descrita por Söderström e Parvinen (1976) e que possuem importante papel durante a espermiogênese, tais como formação do acrossomo, transporte intercelular e formação da cauda do espermatozóide. Isto é explicado pois, segundo Monesi (1965), a transcrição de RNAm cessa nas espermátides iniciais, quando seus núcleos começam a alongar-se, entretanto o processo de síntese continua até os passos finais da espermiogênese, sendo realizado pelos CBs. Porém, muitos estudos deverão ser realizados para a verificação da formação dessas estruturas e, também, a averiguação de sua função.

Podemos verificar, portanto, que os Heteroptera são um ótimo material de estudo e, ainda, há muitas questões a serem respondidas como, por exemplo, qual é a família, o número de lobos testiculares, o número cromossômico e o sistema cromossômico sexual ancestrais. Para a melhor avaliação deste grupo, muitas outras espécies deverão ser avaliadas, assim como, outras técnicas deverão ser utilizadas. 
V. CONCLUSÕES 


\section{CONCLUSÕES}

As análises das espécies Stenocoris (Oryzocoris) furcifera (Alydidae), Acatocephala sp, Acanonicus hahni, Anisoscelis foliacea marginella (Coreidae), Chlorocoris complanatus, Edessa affins, Edessa meditabunda, Loxa deducta, Thyanta perditor (Pentatomidae), Atopozelus opsinus e Doldina carinulata (Reduviidae) permitiram concluir que:

1) Os lobos testiculares de todas as espécies estão dispostos lado a lado com exceção das espécies da família Reduviidae, na qual eles são em forma de ofiuroide;

2) O número de lobos é variável $A$. hahni, A. foliacea marginella, $A$. sp., $C$. complanatus, L. deducta, A. opsimus e D. carinulata apresentaram 7 lobos, $S$. (Oryzocoris) furcifera apresentou 6, E. affins e E. meditabunda apresentaram 4 e $T$. perditor apresentou 3;

3) As espécies Chlorocoris complanatus e Loxa deducta apresentaram o lobo harlequin;

4) Edessa affins e Edessa meditabunda embora não tenham apresentado lobo harlequin, apresentaram a espermiogênese diferenciada;

5) O complemento cromossômico das espécies analisadas foi de $2 \mathrm{n}=13(12 \mathrm{~A}+$ $\mathrm{X} 0$, S. furcifera $), 2 \mathrm{n}=14(12 \mathrm{~A}+\mathrm{XY}$, C. complanatus, E. meditabunda, L. deducta e T. perditor $), 2 \mathrm{n}=16(14 \mathrm{~A}+\mathrm{XY}$, E. affins $), 2 \mathrm{n}=19(18 \mathrm{~A}+\mathrm{X} 0, A$. hahni), $2 \mathrm{n}=21(18 \mathrm{~A}+2 \mathrm{~m}+\mathrm{X} 0$, A. sp. $), 2 \mathrm{n}=26(24 \mathrm{~A}+\mathrm{XY}$, A. opsimus $) \mathrm{e}$ $2 \mathrm{n}=27\left(24 \mathrm{~A}+2 \mathrm{~m}+\mathrm{X} 0\right.$, A. foliacea marginella e $24 \mathrm{~A}+\mathrm{X}_{1} \mathrm{X}_{2} \mathrm{Y}, D$. carinulata) cromossomos;

6) Todas as espécies de Coreidae apresentaram m-cromossomos, exceto $A$. hahni;

7) O comportamento nucleolar durante a meiose diferiu entre as espécies. Foi observado em L. deducta, A. opsimus e D. carinulata a semi-persistência nucleolar e somente em A. hahni e T. perditor houve marcação da RON; 
8) O comportamento do material prata positivo durante a espermiogênese foi semelhante em todas as espécies, diferindo apenas com relação a localização, tamanho, morfologia e intensidade de coloração.

Portanto podemos concluir que um maior número de espécies deverão ser analisadas a fim de definirmos, por exemplo, o número de lobos, número de cromossomos, presença ou não de m-cromossomos, sistema cromossômico do sexo, localização da NOR e definição das estruturas prata positivo durante a espermiogênese. 


\section{REFERÊNCIAS BIBLIOGRÁFICAS}

BRESSA, M.J.; PAPESCHI, A.G.; MOLA, L.M.; LARRAMENDY, M.L.

Meiotic studies in Dysdercus Guérin Méneville 1831 (Heteroptera:

Pyrrhocoridae). I. Neo-XY in Dysdercus albofasciatus Berg 1878, a new sex

chromosome determining system in Heteroptera. Chromosome Research, v. 7, p. 503-508, 1999.

BRESSA, M.J.; PAPESCHI, A.G., MOLA, L.; LARRAMENDY, M.L. Autossomal univalents as a common meiotic feature in Jadera haematoloma and Jadera sanguinolenta (Heteroptera: Rhopalidae: Serinethinae). European Journal of Entomology, v. 98, p. 151-157, 2001.

BRESSA, M.J.; FUMAGALLI, E.; ITUARTE, S.; FRASSA, M.V.;

LARRAMENDY, M.L. Meiotic studies in Dysdercus Guérin Méneville 1831 (Heteroptera: Pyrrhocoridae). II. Evidence on variations of the diffuse stage between wild and laboratory-inbred populations of Dysdercus chaquency Freiberg, 1948. Hereditas, v. 137, p. 125-131, 2002.

BRESSA, M.J.; PAPESCHI, A.G.; FUMAGALLI, E.; VAN DOESBURG, P.H.; LARRAMENDY, M.L. Cytogenetic and nucleolar meiotic cycle analyses in Dysdercus imitator Blõte, 1931 (Pyrrhocoridae, Heteroptera) from Argentina. Folia Biologica (Krakow), v. 51, p. 135-141, 2003.

BOWEN, R. H. Studies on insect spermatogenesis. III. On the structure of the neben-kern in the insect spermatid and the origin of nebenkern patterns. Biol. Bull. v. 41, p. 53-84, 1922. 
BUCK, R.C. Mitosis and meiosis in Rhodnius prolixus: the fine structure of the spindle and difuse kinetochore. Journal of Ultrastructure Research, v. 18, p. 489-501, 1967.

CAMACHO, J.P.M.; BELDA, J.; CABRERO, J. Meiotic behaviour of the holocentric chromosomes of Nezera viridula (Insecta, Heteroptera) analyzed Cbanding and silver impregnation. Canc. J. Gent Cytol, v. 27, p. 490-497, 1985.

CASTANHOLE, M.M.U.; PEREIRA, L.L.V.; SOUZA, H.V.; BICUDO, H.E.M.C.; COSTA L.A.A.; ITOYAMA, M.M. Heteropicnotic chromatin and nucleolar activity in meiosis and spermiogenesis of Limnogonus aduncus (Heteroptera, Gerridae): a stained nucleolar organizing region that can serve as a model for studying chromosome behavior, Genetics and Molecular Research, v. 7, n. 4, p. 1398-1407, 2008.

CATTANI, M.V.; GREIZERSTEIN, E.J.; PAPESCHI, A.G. Male meiotic behaviour and nucleolus organizer regions in Camptischium clavipes (Fabr.) (Coreidae, Heteroptera) analyzed by florescent banding and in situ hybridization. Caryologia, v. 57, n. 3, p. 267-273, 2004.

CATTANI, M.V.; PAPESCHI, A.G. Nucleolus organizing regions and semipersistent nucleolus during meiosis in Spartocera fusca (Thunberg) (Coreidae, Heteroptera). Hereditas, v. 140, p. 105-111, 2004.

CHICKERING, A.M.; BACORN, B. Spermatogenesis in the Belatomatidae. IV. Multiple chromosomes in Lethocerus. Papers of the Michigan Academy of Science, Arts and Letters, v. 17, p. 529-534, 1933. 
COLOMBO P.C.; BIDAU C.J. Estudios cromosómicos en heterópteros argentinos. I. Los cromosomas meióticos de cinco especies de Coreidae. Physis, v. 43, p. 29-40, 1985.

COMINGS, D.E.; OKADA, T.A. Holocentric chromosomes in Oncopeltus: kinetochore plates are present in mitosis but absent in meiosis. Chromosoma (Berl.), v. 37, p. 177-192, 1972.

COSTA, L.C.; AZEREDO-OLIVEIRA, M.T.V. de; TARTAROTTI, E. Spermatogenesis and nucleolar activity in Triatoma klugi (Triatomine, Heteroptera). Genetics and Molecular Biology, v. 31, n. 2, p. 438-444, 2008.

DA CUNHA MARQUES, A.X. (Variously cited as Marques A.X. and XAVIER A. da C.M. - Cariologia comparada de alguns Hemípteros Heterópteros (Pentatomideos e coreideos). Mems. Estud. Mus. Zool. Univ. Coimbra, v. 163, p. 1-116, 1945.

DEY, S. K.; WANGDI, T. Chromosome number and sex chromosome system in forty-four species of Heteroptera. Chromosome Inf. Serv, v. 45, p. 5-8, 1988.

FOSSEY, A.; LIEBENBERG, H. Meiosis and nucleolar structures in the stink bug Cartisis wahlbergi Stal (Coreidae: Heteroptera) Cytobios, v. 81, p. 7-15, 1995.

FROESCHNER, R. C. Family Alydidae Amyot and Serville, 1843. Pp. 4-11 in T. J. Henry and R. C. Froeschner [eds.], Catalog of the Heteroptera, or True Bugs, of Canada and the Continental United States. E. J. Brill, London, U. K. 658 pp. 1988 
GONZÁLEZ-GARCIA, J.M.; ANTONIO, C.; SUJA, J.A.; RUFAS, J.S. Meiosis in holocentric chromosomes: kinetic activity is randomly restricted to the chromatid ends of sex univalents in Graphosoma italicum (Heteroptera). Chromosome Research, v. 4, p. 124-132, 1996.

GROZEVA, S.M.; KUZNETSOVA, V.G. Karyotypes and some structural properties of the reproductive system of bugs of the subfamily Artheneinae (Heteroptera, Pentatomorpha, Lygaeidae). Entomologicheskoye Obozreniye, n. 4, p. 700-709, 1989.

GROZEVA, S.M.; KUZNETSOVA, V.G. The reproductive system of some bug families (Heteroptera, Pentatomomorpha).- In: Advances in Reproduction of Insect Reproduction (eds B. BENNETOVA, I. GELBIC and T. SOLDAN), Institute of Entomology, Czech Academy of Science, p. 97- 102, 1992.

GROZEVA, S.; NOKKALA, S. Chromosomes and their behaviour in two families of the primitive infraorder Dipsocoromorpha (Heteroptera). Hereditas, v. 125, p. 31-36, 1996.

HALKKA, O. Chromosome studies on the Hemiptera Homoptera Auchenorryncha. Annales Academiae Scientiarum Fennicae., v. 43, p. 1-71, 1959.

HEALY, J.M.; JAMIESON, B.G.M. An ultrastructural ex-amination of developing and mature paraspermatozoa in Pyrazus ebeninus (Mollusca Gastropoda, Potamididae). Zoomorphol. v. 98, p. 101-119, 1981. 
HOFGARTNER, F. J.; SCHMID, M.; KRONE, W.; ZENZES, M. T.; ENGEL, W. Pattern of activity of nucleolus organizers during spermatogenesis in mammals as analyzed by silverstaining. Chromosoma, v. 71, p. 197-216, 1979.

HOWELL W.M.; BLACK, D.A. Controlled silver-staining of nucleolus organizer regions with a protective colloidal developer: a 1-step method. Experientia, v. 36, p. $1014-1015,1980$.

HUGHES-SCHRADER, S.; SCHRADER, F. The Kinetochore of the Hemiptera. Chromosoma, v. 12, p. 327-350, 1961.

JACOBS, D.H. The evolution of a neo-XY1Y2 sex chromosome system by autosome sex chromosome fusion in Dundocoris nodulicarius Jacobs (Heteroptera: Aradidae: Carventinae). Chromosome Research, v. 12, p. 175-191, 2004.

JANDE, S.S. An analysis of the chromosomes in four species of the family Belostomatidae (Heteroptera, Cryptocerata). Research Bulletin (NS) Panjab University, v. 10, p. 25-34, 1959.

JOHN, B.; KING, M. Pseudoterminalization, terminalization and non-chiasmate modes of terminal association. Chromosoma, v. 92, p. 89-99, 1985.

JONES, G.H. Chiasmata. In: Monees PB, ed., Meiosis. Orlando: Academic Press, p. 213-244, 1987.

KIRILLOVA, V.I. Chromosome numbers of leafhoppers (Homoptera, Auchenorrhyncha) of the world fauna. I. Superfamilies Fulgaroidea, Cercopoidea, Cicadoidea. Entomologiceskoe obozrenie, v. 65, p. 115-125, 1986. 
KIRILLOVA, V.I. Chromosomes numbers of leafhoppers (Homoptera, Auchenorrhyncha) of the world fauna. I. Karyotype peculiarities of the leafhoppers of the superfamilies Fulgaroidea, Cercopoidea, Cicadoidea . Entomologiceskoe obozrenie, v. 66, p. 321-337, 1987.

LANZONE C.; SOUZA M.J.de. Chromosome complement and meiosis in three species of the Neotropical bug genus Antiteuchus (Heteroptera, Pentatomidae, Discocephalinae). Genet. Mol. Biol., vol. 29, n.1, p. 49-55, 2006.

LESTON, D. Results from the Danish expedition to the French Cameroons 194950. IX. Hemiptera, Pentatomoidea. Bulletin de I'Institut Français d'Afrique Noire (A). v. 18, p, 618-626, 1956.

MANNA, G.K. Chromosomes in evolution in Heteroptera. In: SHARMA, A.K., ed. Chromosomes in evolution of Eukaryotic groups. Boca Ratton Florida USA: CRCPress, p. 189-225, 1984.

MANNA, G. K. A study of the chromo-somes during meiosis in forty-three species of Indian Heteroptera. Proc. Zool. Soc., Bengal, v. 4, p. 1-116, 1951.

McLAIN, D.K.; MARSH, N.B. Male copulatory success: heritability and relationship to mate fecundity in the southern green stinkbug, Nezara viridula (Hemiptera: Pentatomidae). Heredity. v. 64, p. 161-167, 1990.

McLAIN, D. K. Non-genetic benefits of mate choice: fecundity enhancement and sexy sons. Animal Behaviour, n. 55, p.1191-1201, 1998. 
MEYES, F. Uber oligopyrene und apyrene Spermien und uber ihre Entstehung nach Beobachtungen an Paludina und Pygera. Arch Mikrosk Anat Entw Mech, v. 61, p. 1-83, 1903.

MOLA, L. M.; PAPESCHI, A. G. Karyotype evolution in Arshnn (Aeshnidae, Odonata). Lund, Sweden. Hereditcts, v. 121, p. 185-189, 1994.

MONESI, V. Synthetic activities during spermatogenesis in the mouse. Experimental Cell Research, v. 39, n. 1, p. 197-224, 1965.

MOTZKO, D.; RUTHMANN, A. Spindle membranes in mitosis and meiosis of the heteropteran insect Dysdercus intermedius. A study of the interrelationship of spindle architecture and the kinetic organization of chromosomes. European Journal of Cell Biology, v. 33, p. 205-216, 1984.

NOKKALA, S.; NOKKALA, C. Achiasmatic male meiosis in two species of Saldula (Saldidae, Hemiptera). Hereditas, v. 99, n. 1, p. 131-134, 1983.

NOKKALA, S.; NOKKALA, C. The occurrence of the XO sex chromosome system in Dictyonota tricornis (Schr.) (Tingidae, Hemiptera and its significance for concepts of sex chromosome system evolution in Heteroptera. Hereditas, v. 100, p. 299-301, 1984.

NOKKALA, S., GROZEVA, S.; KUZNETSOVA, V.; MARYANSKANADACHOWSKA, A. The origin of the achiasmatic XY sex chromosome system in Cacopsylla peregrina (Frst.) (Psylloidea, Homopetera). Genetica, v. 119 , p. 327-332, 2003. 
PANZERA F.; ALVAREZ F.; SANCHEZ-RUFAS J.; PEREZ R.; SUJA J.A.; SCVORTZOFF E.; DUJARDIN J.P.; ESTRAMIL E.; SALVATELLA R. Cheterochromatin polymorphism in holocentric chorosomes of Triatoma infestans (Hemiptera: Reduviidae). Genome, v. 35, p.1068-1074, 1992.

PANZERA F.; PEREZ R.; PANZERA Y.; ALVAREZ F.; SCVORTZOFF E.;SALVATELLA R. Karyotype evolution in holocentric chromosomes of three related species of Triatominae (Hemiptera: Reduviidae). Chrom Res, v. 3, p. 143$150,1995$.

PANZERA F.; PEREZ R.; HORNOS S.; PANZERA Y.; CESTAU, R.; DELGADO V.; NICOLINI P. Chromosome numbers in the Triatominae (Hemiptera-Reduviidae): a review. Mem. Inst. Oswaldo Cruz, v. 91, p. 515-518, 1996.

PANZERA F.; SCVORTZOFF E.; PÉREZ R.; PANZERA Y.; HORNOS S.; CESTAU R.; NICOLINI P.; DELGADO V.; ALVAREZ F.; MAZZELLA M.; COSSIO G.; MARTÍNEZ M.; SALVATELLA R. Citogenetics of triatomines, p. 621-664. In R Carcavallo, Atlas de Triatominos de América, Fundação Oswaldo Cruz, Rio de Janeiro,1998.

PAPESCHI, A.G.; BIDAU C.J. Chromosome complement and male meiosis in four species of Belastoma Latreille (Heteroptera-Belostomatidae). Rev. Brasil. Genet. VIII, v. 2, p. 249-261, 1985.

PAPESCHI, A.G; BRESSA, M.J. Cytogenetic studies in Belostomatidae from Argentina. Abstracts of the second quadrennial meeting of the International Heteropteristis Society, v. 46, 2002. 
PAPESCHI, A.G.; MOLA, L.M.; BRESSA, M.J.; GREIZERSTEIN, E.J.; LÍA, V.; POGGIO, L. Behaviour of ring bivalents in holocentric systems: Alternative sites of spindle attachment in Pachylis argentinus and Nezara viridula (Heteroptera). Chromosome Research, v. 11, p. 725-733, 2003.

REBAGLIATI, P.; PAPESCHI, A.G.; MOLA, L.M. Meiosis and fluorescent banding in Edessa meditabunda and E. rufomarginata (Heteroptera: Pentatomidae: Edessinae). European of Journal Entomology, v. 100, p. 11-18, 2003.

REBAGLIATI, P.J.; MOLA, L.M.; PAPESCHI, A.G.; GRAZIA, J. Cytogenetics studies in Pentatomidae (Heteroptera): A review. J.Zool Syst Evol Res, v. 43, p. 199-213, 2005.

RUFAS, J.S.; GIMÉNEZ-MARTÍN, G. Ultrastructure of the kinetochore in Graphosomaitalicum (Hemiptera: Heteroptera). Protoplasma, v. 32, p. 142-148, 1986.

SANDS, V. E. Cytological studies of the Coreidae and Alydidae (Hemiptera: Heteroptera). II. Karyological changes exemplified by Malaysian genera. Caryologia, v.35, p.335-345, 1982.

SATAPATHY, S. N.; PATNAIK, S. C. Chromosome numbers in fourty-one species of Indian Heteroptera. Chromosome Inf. Serv, v. 47, p. 3-5, 1989.

SCHAEFER C.W.; PANIZZI A. R. Heteroptera of economic importance. Ed. CRC Press, p. 421-474, 2000. 
SCHRADER, F. Notes on the mitotic behaviour of long chromosomes. Cytologia (Tokio), v. 6, p. 422-430, 1935.

SCHRADER, F. The formation of tetrads and the meiotic mitoses in the male of Rhytidolomia senilis Say (Hemiptera, Heteroptera). Journal of Morphology, v. 67, p. 123-141, 1940.

SCHRADER, F. Regular occurrence of heteroploidy in a group of Pentatomidae (Hemiptera). Biol. Bull., v. 88, p. 63-70, 1945a.

SCHRADER, F. The cytology of regular heteroploidy in the genus Loxa (Pentatomidae - Hemiptera). J. Morphol., v. 76, p. 157-177, 1945 b.

SCHRADER, F. The elimination of chromosomes in the metiotic divisions of Brachystethus rubromaculatus Dallas. Biol. Bull., v. 90, p. 19-31, 1946 .

SCHRADER, F. Autossomal elimination and preferential segregation in the harlequin lobe of certain Discocephalini (Hemiptera). Biol. Bull., v. 90, p. 264$290,1946 b$.

SCHRADER, F. Cytological and evolutionary implications of aberrant chromosome behavior in the harlequin lobe of some Pentatomidae (Heteroptera). Chromosoma, v. 11, p. 103-128, 1960a.

SCHRADER, F. Evolutionary aspects of aberrant meiosis in some Pentatomidae (Heteroptera). Evolution, v. 14, p. 498-508, 1960 b. 
SCHRADER, F.; LEUCHTENBERGER, C. A cytochemical analysis of the functional interrelations of various cell structures in Arvelius albopunctatus (DE GEER). Experimental Cell Research, v. 1, p. 421-452, 1950.

SCHUH, T. T.; SLATER, J.A. The bugs of the world (Hemiptera:

Heteroptera) Classification and natural history, Cornell UNIVERSITY press, 1995.

SILBERGLIED, R. E.; SHEPPERD, J. G.; DICKINSON, J. L. Eunuchs: the role of apyrene sperm in lepidoptera? Am. Nat. v. 123, p.255-265, 1984.

SIVINSKI, J. Sexual selection and insect sperm. Florida Ent. v. 63, p. 99-111, 1980.

SNOOK, R.R.; MARKOW, T.A.; KARR, T. L. Functional nonequivalence of sperm in Drosophila pseudoobscura. Proceedings of the National Academy of Sciences of the United States of America, n. 91, p.11222-11226, 1994.

SÖDERSTRÖM K.O.; PARVINEN M. Transport of material between the nucleus, the chromatoid body and the golgi complex in the early spermatids of the rat. Cell and Tissue Research, v. 168, n. 3, p. 335-342, 1976.

SOLARI, A.; AGOPIAN, S. Recombination nodules, synaptonemal complexes and heterochromatin in the hemipteran Triatoma infestans . Microscopia Eletronica y Biologia Celular, v. 11, p. 179-195, 1987.

SOUZA, H. V.; BICUDO, H. E. M. C.; COSTA L. A. A.; ITOYAMA, M. M. A study of meiosis and spermatogenesis in different testicular lobes of Antiteuchus tripterus (Heteroptera, Pentatomidae). European Journal of Entomology, 2007a. 
SOUZA, H.V.; BICUDO, H. E. M. C.; ITOYAMA, M.M. Study of chromosomal and nucleolar aspects in testes of Nysius californicus (Heteroptera: Lygaeidae). Genetics and Molecular Research, v. 6, n. 1, p. 33-40, $2007 \mathrm{~b}$.

SOUZA, H. V.; CASTANHOLE, M. M. U.; BICUDO, H. E. M. C.; COSTA L. A. A.; ITOYAMA, M. M. Morphological patterns of the heteropycnotic chromatin and nucleolar material in meiosis and spermiogenesis of some Pentatomidae (Heteroptera). Genetics and Molecular Biology, v. 31, n. 3, p. 686691, 2008.

SUMNER, A.T. Chromosome Banding. Unwin Hyman, London, 1990.

SWALLOW, J. G.; WILKINSON, G. S. The long and the short of sperm polymorphisms in insects. Biol. Rev. v. 77, p.153-182, 2002.

TARTAROTTI E.; AZEREDO-OLIVEIRA M.T.V. Patterns of nucleolar activity during spermatogenesis of two triatomines, Panstrongylus megistus and $P$. herreri. Caryologia, v. 52, p. 177-184, 1999.

TAVARES, M. G.; AZEREDO-OLIVEIRA, M.J.V. Pattern of nucleolar activity during spermatogenesis in triatomines (Heteroptera: Reduvidae) as analysed by silver staining. Cytobios, v. 89, p. 93-103, 1997.

UESHIMA, N. Animal cytogenetics, Insecta 6, Hemiptera: Heteroptera. Gebruder Borntraeger: Berlin, Stuttgart, 1979.

UESHIMA, N.; Ashlock P.D. Cytotaxonomy of the Lygaeidae (Heteroptera). Univ. Kans. Sci. Bull., v 51, p. 717-801, 1980. 
WHITE, M.J.D., Animal Cytology and Evolution, $3^{\text {rd }}$ ed. Cambridge University Press, 1973.

WILSON, E.B. Studies of chromosomes II. The paired microchromosomes, idiochromosomes and heterotropic chromosomes in Hemiptera. The Journal of Experimental Zoology. , v. 2, p. 507-545, 1905.

WOLF, K.W. Acetilation of $\alpha$-tubulin in male meiotic spindles of Pyrrhocoris apterus, an insect with holocentric chromosomes. Protoplasma, v. 191, p. 148157, 1996. 


\section{ANEXOS}

\section{MATERIAL E MÉTODOS}

\subsection{Obtenção e Armazenamento dos Insetos}

Para a análise citogenética, foram coletados em torno de 15 indivíduos machos adultos de cada espécie das famílias Alydidae (Stenocoris (Oryzocoris) furcifera), Coreidae (Acatocephala sp, Acanonicus hahni e Anisoscelis foliacea marginella), Pentatomidae (Chlorocoris complanatus, Edessa affins, Edessa meditabunda, Loxa deducta e Thyanta perditor) e Reduviidae (Atopozelus opsinus e Doldina carinulata), em pés de ipê branco (Tabebuia roseo-alba), abobrinha (Cucurbita pepo), roseira (Rosa sp.), maracujá (Passiflora suberosa), pitanga (Eugenia uniflora), pitanga (Eugenia uniflora), boldo (Plectranthus barbatus), pitanga (Eugenia uniflora), capim (Andropogon citratus), capixingui (Croton floribundus) e ipê-amarelo (Tabeluia sp), respectivamente, na cidade de São José do Rio Preto (2047’32’S, 49²1'37’W), $\mathrm{SP}$, Brasil. Os insetos foram transportados até o laboratório de Citogenética e Molecular de Insetos do Departamento de Biologia, IBILCE/UNESP, montados para encaminharmos para a identificação ou para a nossa coleção ou fixados em metanol:ácido acético $(3: 1)$ ou etanol absoluto e armazenados no refrigerador, para posteriores análises. A identificação dos insetos foi realizada pelo Prof. Dr. Luiz Antônio Alves Costa do Departamento de Entomologia do Museu Nacional do Rio de Janeiro, RJ; Dr. José Antônio Marin Fernandes da Universidade Federal do Pará, PA e o Dr. Hélcio Gil Santana do Instituto Oswaldo Cruz, RJ.

\subsection{Dissecação dos Insetos}

Após a coleta, os insetos, machos adultos, foram eterizados e dissecados, já que a espermatogênese em Heteroptera não se encerra no estágio de ninfa. Para a dissecção o inseto foi fixado com um alfinete na região posterior do 
cefalotórax em uma placa de Petri contendo parafina sólida e teve suas patas, asas, escutelo e laterais do abdome seccionados com uma tesoura pequena e pontiaguda. Foi gotejado uma gota de solução fisiológica de Demerec sobre os órgãos expostos, estes foram removidos com auxílio de um estilete, deixando evidente os testículos. Os testículos, localizados latero-ventralmente, foram mantidos em sua posição por meio de ramificações dos troncos das traquéias dos respectivos segmentos. Uma membrana de coloração variável (de transparente à vermelha) envolve os testículos em cujo interior localizam-se as células germinativas em diferentes estágios de desenvolvimento.

\subsection{Colorações}

\subsubsection{Orceína Lacto-Acética}

Os testículos extraídos, conforme descrito anteriormente tiveram os lobos separados e corados com orceína lacto-acética, para sua caracterização morfológica. Em seguida, os lobos foram individualmente submetidos a esmagamento para o estudo citogenético da meiose e espermiogênese.

\subsubsection{Impregnação com Nitrato de Prata (HOWELL; BLACK, 1980, com modificações)}

Os insetos foram dissecados em solução fisiológica de Demerec e os túbulos seminíferos transferidos para solução de ácido acético a 45\% por 1 minuto e, posteriormente, ácido lático a $50 \%$ por 5 minutos. $\mathrm{O}$ material foi esmagado em ácido acético a 45\%. As lâminas ficaram em câmara úmida por 10 minutos e a lamínula foi retirada com auxílio de nitrogênio líquido. As lâminas foram guardadas para o envelhecimento.

As lâminas envelhecidas foram tratadas com uma gota de solução reveladora (solução de gelatina a 2\%); posteriormente, foram adicionadas duas gotas de nitrato de prata a $50 \%$, o material foi coberto com lamínula e incubado 
em estufa a $60^{\circ} \mathrm{C}$ por 10 minutos em câmara úmida até o aparecimento de coloração marrom dourada. A lâmina foi lavada com água destilada para desprendimento da lamínula e recebeu dois banhos de água destilada secando à temperatura ambiente. Após um dia, a lâmina foi montada com verniz cristal para análise.

\subsection{Análise das lâminas}

As lâminas foram analisadas no microscópio de luz, Olympus modelo BX40, do Laboratório de Citogenética e Molecular de Insetos. As imagens foram analisadas em microscópio Zeiss, AXIOSKOP 2, sendo as imagens capturadas pelo software Digital Image Processing AXIONVISION 3.1 (Zeiss) acoplado ao mesmo, do Laboratório de Morfologia, do Departamento de Biologia do IBILCE/UNESP, Campus de São José do Rio Preto, SP. 


\section{Resumo}

Os aspectos da espermatogênese e do comportamento nucleolar foram analisados em Stenocoris (Oryzocoris) furcifera (Alydidae), Acatocephala sp, Acanonicus hahni, Anisoscelis foliacea marginella (Coreidae), Chlorocoris complanatus, Edessa affins, Edessa meditabunda, Loxa deducta, Thyanta perditor (Pentatomidae), Atopozelus opsinus e Doldina carinulata (Reduviidae). Os lobos testiculares de todas as espécies estão dispostos lado a lado com exceção das espécies da família Reduviidae, na qual eles são em forma de ofiuroide. $O$ complemento cromossômico encontrado foi de $2 \mathrm{n}=13$ (12A + X0, S. furcifera), $2 \mathrm{n}=14(12 \mathrm{~A}+\mathrm{XY}$, C. complanatus, E. meditabunda, L. deducta e T. perditor $)$, $2 \mathrm{n}=16(14 \mathrm{~A}+\mathrm{XY}$, E. affins $), 2 \mathrm{n}=19(18 \mathrm{~A}+\mathrm{X} 0$, A. hahni $), 2 \mathrm{n}=21(18 \mathrm{~A}+2 \mathrm{~m}+$ $\mathrm{X} 0$, A. sp. $), 2 \mathrm{n}=26(24 \mathrm{~A}+\mathrm{XY}, A$. opsimus $)$ e $2 \mathrm{n}=27(24 \mathrm{~A}+2 \mathrm{~m}+\mathrm{X} 0, A$. foliacea marginella e $24 \mathrm{~A}+\mathrm{X}_{1} \mathrm{X}_{2} \mathrm{Y}$, D. carinulata) cromossomos. Todas as espécies da família Coreidae apresentaram m-cromossomos, com exceção de $A$. hahni. As espécies da família Pentatomidae C. complanatus e L. deducta apresentaram lobo harlequin e as espécies E. affins e E. meditabunda embora não tenham apresentado lobo harlequin, apresentaram espermiogênese diferenciada. $O$ comportamento meiótico de todas as espécies analisadas foi semelhante, isto é, apresentaram: cromossomos holocêntricos, material heteropicnótico na prófase; quiasmas intersticiais e/ou terminais; primeira divisão reducional para os autossomos e o inverso para os cromossomos sexuais. Com relação ao comportamento nucleolar, somente as espécies $A$. hahni e T. perditor apresentaram marcação da RON. Foi observada semi-persistência nucleolar nas espécies $L$. deducta, A. opsimus e D. carinulata. Nas demais espécies a marcação da RON foi bastante discreta, não sendo possível afirmar com clareza onde ela está localizada. O comportamento do material prata positivo durante a espermiogênese foi semelhante em todas as espécies, diferindo apenas com relação a localização, tamanho, morfologia e intensidade de coloração. Portanto podemos concluir que um maior número de espécies deverão ser analisadas a fim de definirmos, por exemplo, o número de lobos, número de cromossomos, 
presença ou não de m-cromossomos, sistema cromossômico do sexo, localização da NOR e definição das estruturas prata positivo durante a espermiogênese.

Palavras-chave: Heteroptera; Alydidae; Pentatomidae; Coreidae; Reduviidae, meiose; espermiogênese, comportamento nucleolar. 


\section{Abstract}

The aspects of spermatogenesis and nucleolar behaviour were analyzed in Stenocoris (Oryzocoris) furcifera (Alydidae), Acatocephala sp, Acanonicus hahni, Anisoscelis foliacea marginella (Coreidae), Chlorocoris complanatus, Edessa affins, Edessa meditabunda, Loxa deducta, Thyanta perditor (Pentatomidae), Atopozelus opsinus e Doldina carinulata (Reduviidae). The testicular lobes of all species are placed side by side with the exception of species of the family Reduviidae, in which they are in the form of ophiuroids. The complement chromosome was $2 \mathrm{n}=13(12 \mathrm{~A}+\mathrm{X} 0, S$. furcifera $), 2 \mathrm{n}=14(12 \mathrm{~A}+\mathrm{XY}, C$. complanatus, E. meditabunda, L. deducta e T. perditor $), 2 \mathrm{n}=16(14 \mathrm{~A}+\mathrm{XY}, E$. affins), $2 \mathrm{n}=19(18 \mathrm{~A}+\mathrm{X} 0, A$. hahni), $2 \mathrm{n}=21(18 \mathrm{~A}+2 \mathrm{~m}+\mathrm{X} 0, A . \mathrm{sp}),. 2 \mathrm{n}=26$ $(24 \mathrm{~A}+\mathrm{XY}$, A. opsimus $)$ e $2 \mathrm{n}=27(24 \mathrm{~A}+2 \mathrm{~m}+\mathrm{X} 0$, A. foliacea marginella and $24 \mathrm{~A}+\mathrm{X}_{1} \mathrm{X}_{2} \mathrm{Y}$, D. carinulata) chromosomes. All species of the family Coreidae presented m-chromosomes, except for A. hahni. The species of the family Pentatomidae C. complanatus and L. deducta presented harlequin lobe and the species E. affins and E. meditabunda although they showed no harlequin lobe showed spermiogenesis differentiated. The meiotic behavior of all species analyzed was similar: holocentric chromosomes, heteropicnotic material at prophase; chiasmas interstitial and/or terminal; first reductional division for the autosomes and the reverse for the sex chromosomes. With regard to the nucleolar behavior, only the species A. hahni and T. perditor presented labeling of RON. Was observed nucleolar semi-persistence in species L. deducta, A. opsimus e D. carinulata. In other species the marking of RON was very discreet, is not possible to state clearly where it is located. The behavior of the silver positive material during spermiogenesis was similar in all species, differing only with respect to location, size, morphology and staining intensity. So we can conclude that a greater number of species should be considered in order to define, for example, the number of lobes, the number of chromosomes, presence or absence of mchromosomes, sex chromosome system, the location of NOR and definition silver structures positive during spermiogenesis. 
Keywords: Heteroptera; Alydidae; Pentatomidae; Coreidae; Reduviidae; meiosis; spermiogenesis, nucleolar behaviour. 